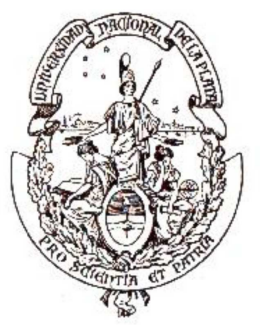

Universidad Nacional de La Plata

Facultad de Humanidades y Ciencias de la Educación

Secretaría de posgrado

\title{
ANÁLISIS DE LOS CONCEPTOS CUERPO Y EDUCACIÓN EN LA PERSPECTIVA DE HANNAH ARENDT
}

\author{
Prof. Nicolás Patierno (UNLP)
}

Tesis para optar por el grado de Magíster en Educación Corporal

Director: Dr. Ricardo Crisorio (UNLP)

Co-directora: Dra. Anabella Di Pego (UNLP) 


\section{Índice}

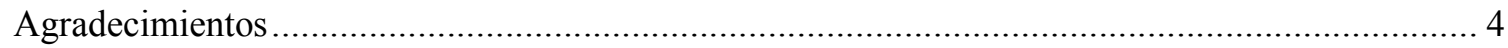

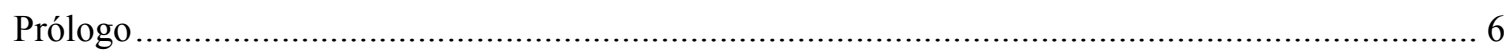

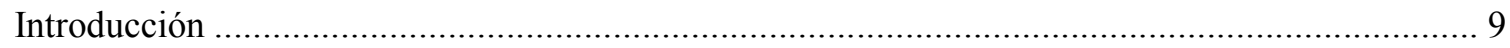

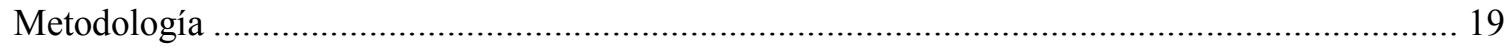

Capítulo 1. La alternativa al positivismo como punto de partida ................................................. 22

1.1 Discusiones en torno a la fenomenología de Edmund Husserl y su relación con el

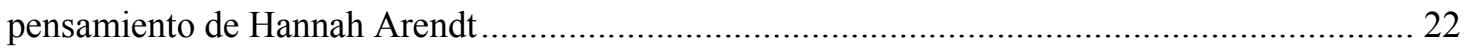

1.2 Entre lo humano y lo natural ¿Dónde hallar un punto de partida?......................................... 25

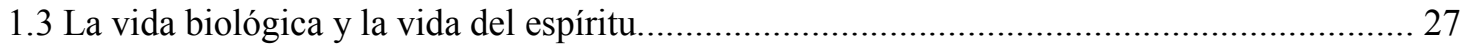

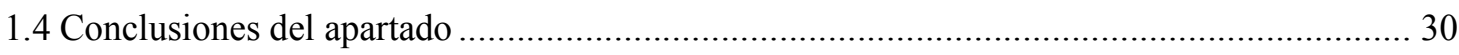

Capítulo 2. Cuerpo y naturaleza en La condición humana .......................................................... 32

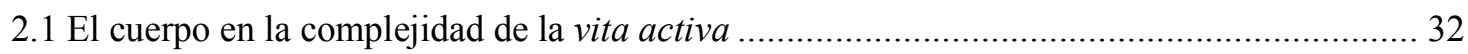

2.2 Las actividades vinculadas a la labor y los procesos vitales del cuerpo................................. 36

2.3 El cuerpo alienado a la incesante demanda del trabajo ......................................................... 40

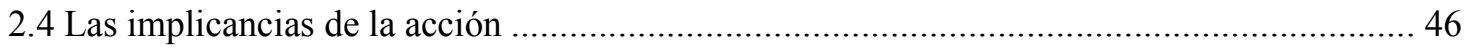

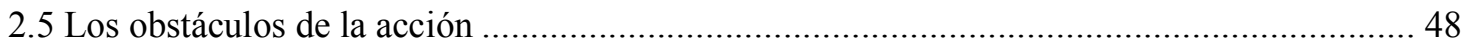

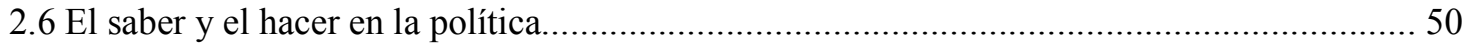

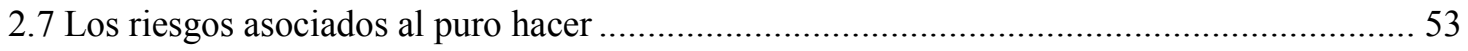

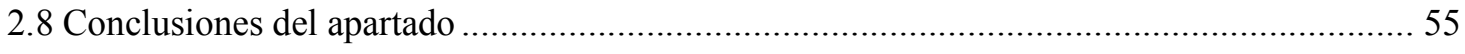

Capítulo 3. Reflexiones en torno a la educación del cuerpo …………........................................... 56

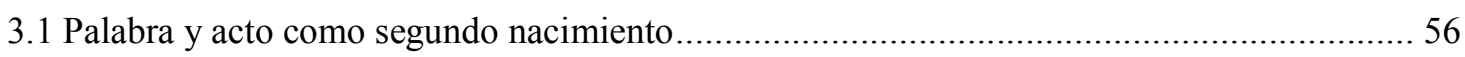

3.2 El saber de la mente y el hacer del cuerpo en el campo de la educación................................ 58

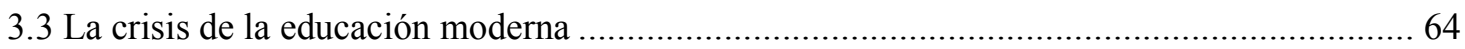

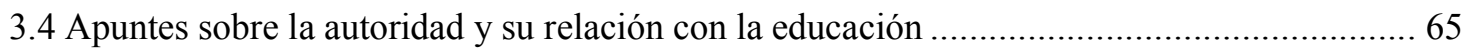

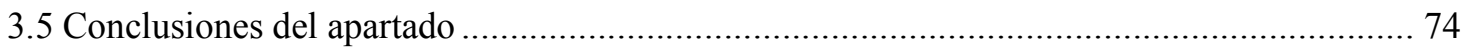

Capítulo 4. El cuerpo como instrumento y objetivo de la violencia ............................................... 75

4.1 ¿Por qué la violencia es un problema de investigación? ...................................................... 75

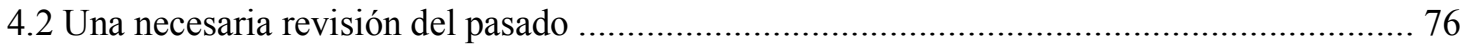

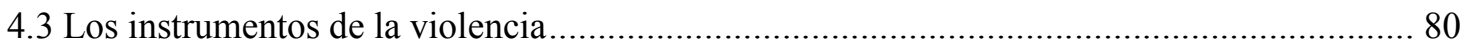

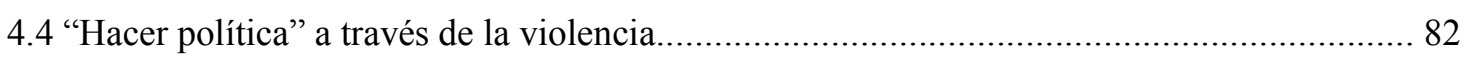




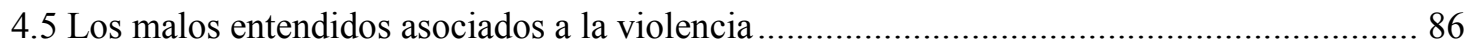

4.6 La fuerza del cuerpo versus la mediación del lenguaje ....................................................... 89

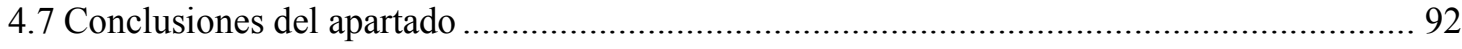

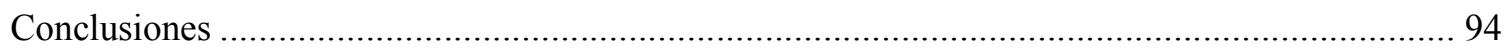

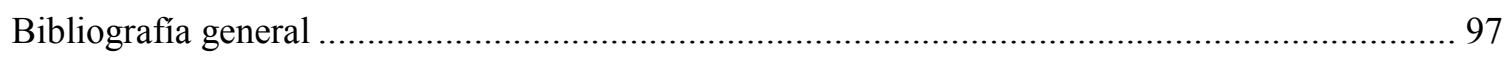

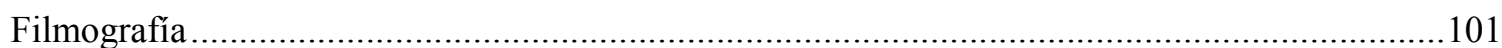




\section{Agradecimientos}

En primer lugar, quisiera agradecer a la Universidad Nacional de La Plata, institución que a partir de sus becas me permitió acercarme con "dedicación exclusiva" al mundo de la investigación. Sin su financiamiento, este trabajo hubiera quedado postergado por algunos años más.

A mi director, Ricardo Crisorio, por su permanente colaboración y fundamentalmente por enseñarme a golpear más fuerte las puertas cuando no se abrían; también por contagiarme esa incansable pasión por indagar absolutamente todo, y por ayudarme a allanar el camino para alejarme poco a poco del peligroso conformismo irreflexivo de las rutinas. También a Anabella Di Pego, mi codirectora, por la excelente predisposición que tuvo desde el primer momento, aceptando plazos más que pretensiosos y esmerándose en un minucioso trabajo de revisión. Sin sus aportes, esta tesis estaría condenada a un mero recorte documental; su profesionalismo en relación a la obra de Hannah Arendt es digno de admiración. Y no quisiera dejar de mencionar a Myriam Southwell, ya que sus consejos en relación al tema de la educación moderna fueron de suma importancia para la confección del presente trabajo.

Quiero dar gracias también a los miembros del Centro Interdisciplinario Cuerpo, Educación y Sociedad, a mis colegas y profesores de la Maestría en Educación Corporal cohortes 2013-2014, al departamento de Educación Física y a la cátedra de Educación Física 5, por el constante diálogo y por permitirme ser parte de sus vidas, compartiendo mates y proyectos y haciendo más interesante la mal llamada "solitaria" tarea de investigar.

Sin los esfuerzos desinteresados de María Cristina Daponte en las traducciones solicitadas, esta tesis carecería de material referencial confiable. Espero contar con su ayuda en los próximos desafíos, ya que su aporte y sabiduría resultan sumamente necesarios.

Quiero destacar el profesionalismo de Bruno Crisorio en el proceso de revisión final y agradecer sus comentarios en relación al estilo de escritura.

La presente tesis no hubiera sido posible sin la ayuda de los Doctores Altair Alberto Fávero y Telmo Marcon (Universidade de Passo Fundo, Brasil), no solo por facilitarme 
herramientas teóricas fundamentales, sino también por el acompañamiento durante la estancia de investigación (en UPF) entre los meses de febrero y marzo de 2016.

Deseo agregar también a mis padres Elvira y Carmelo, a mi hermana Eva y a mi abuela Edith, quienes debieron padecer mis ausencias y locuras "por la tesis"; su ayuda me acompaña en cada paso que doy, cada palabra de esta tesis es para ustedes. Aquí es necesario agregar una mención especial para Edith, ya que su ayuda en relación a las correcciones gramaticales y ortográficas fue de suma importancia para culminar el trabajo de redacción.

Quiero sumar a Giuliana por escucharme, por bancarme las madrugadas en las que hablo solo, por estar siempre a pesar de las obligaciones y por su amor incondicional. Con el mismo amor, esta tesis también te pertenece.

Por último pero no menos importante, quiero agregar a mis amigos, esos hermanos y hermanas de la vida que me acompañan en todo momento; a ellos también está dedicado este trabajo. 


\section{Prólogo}

Hannah Arendt vivió entre los años 1906 y 1975; de origen judío y nacionalidad alemana, sufrió la persecución, encierro y destierro producto de las políticas antisemitas del régimen Nacionalsocialista alemán de comienzos de la década de 1930. Con un doctorado en filosofía, en 1941 migró a Estados Unidos tras escapar de un campo de concentración en Gurs, Francia; su condición de apátrida y refugiada en pleno desarrollo de la Segunda Guerra Mundial influyó determinantemente en su producción teórica. Una vez reiniciado su trabajo académico en Estados Unidos, no tardó en publicar numerosos libros, ensayos y artículos pronunciando su rechazo hacia los regímenes totalitarios y antisemitas, responsables del Holocausto durante la Segunda Guerra Mundial. La autora en cuestión compartió amistades con pensadores fundamentales del siglo XX, entre los que figura Martin Heidegger, influencia insoslayable en los comienzos de su carrera académica en Alemania. Su obra también estuvo influenciada por los aportes de Karl Jaspers, quien dirigió su tesis de Doctorado en Filosofía (en la Universidad de Heidelberg), y Walter Benjamin, con quien mantuvo una íntima amistad hasta su suicidio en 1940.

En su recorrido profesional no solo fue reconocida como filósofa política; también desempeñó labores como maestra de escuela superior, fue profesora en varias universidades y publicó varios ensayos sobre diversas problemáticas contemporáneas para la revista estadounidense New Yorker, entre los que se destacan sus informes sobre el juicio a Adolf Eichmann. En estos escritos Arendt destaca que, por encima de la maldad humana en todo su potencial, es la incapacidad de pensar y juzgar por sí mismo lo más preocupante que sale a la luz en el transcurso del juicio al funcionario nazi. ${ }^{1}$ A diferencia de la mayoría de la prensa mundial, y especialmente del fiscal, que veía a Eichmann como un demonio maligno entre los mortales, la filósofa no encuentra ningún tipo de maldad innata en este personaje corriente de la administración pública alemana.

Esta interpretación de la maldad como una mera banalidad, como algo mundano, es fundamental para entender su obra en relación al Holocausto, así como su posicionamiento

\footnotetext{
${ }^{1}$ Una breve cita de La banalidad del mal da cuenta de esta reinterpretación de la maldad asociada al funcionario nazi enjuiciado: "Eichmann no era estúpido. Únicamente la pura y simple irreflexión -que en modo alguno podemos equiparar a la estupidez- fue lo que le predispuso a convertirse en el mayor criminal de su tiempo. Y si bien esto merece ser clasificado como «banalidad», e incluso puede parecer cómico, y ni siquiera con la mejor voluntad cabe atribuir a Eichmann diabólica profundidad (...)” (Arendt 1999: 273).
} 
crítico. Al quitar los prejuicios sociales y religiosos respecto de la maldad humana, sale a la luz un hecho aún más destacable, la falta de juicio sobre los propios actos y el establecimiento de un sistema administrativo que impide participar con criterio ni reflexión. Estas características, lejos de ser intrascendentes, pueden mantener en funcionamiento una estructura política basada en el exterminio, como ocurrió con los totalitarismos del siglo XX.

A partir de reflexiones de este tipo, es posible rastrear en la obra de la autora varios ensayos vinculados a hechos de la vida cotidiana, sin desatender su relación lógica con aquellos problemas que históricamente recibieron mayor relevancia académica (como la historia, la política, las revoluciones, el poder, el racismo, la educación, entre otros). Un ejemplo en este sentido puede hallarse en la interpretación del hombre moderno como un ser irreflexivo (producto del automatismo burocrático y sistémico llevado a cabo por las políticas de los Estados modernos, con particular atención en los Estados del siglo XX). Se destacan en la teoría de Arendt varios pensamientos en torno a la sociedad de masas y la consecuente impersonalidad de sus acciones, y advertencias, con base en las experiencias totalitarias del siglo XX, sobre la peligrosidad de un mundo social irreflexivo. Algo tan cotidiano como el aparato burocrático de los Estados modernos, tan naturalizado en nuestros días, se halla entre las más eficaces formas de violencia amparadas en el anonimato y en la humanidad limitada del animal laborans -metáfora exponencial de un ser carente de pensamiento y acción propios, más preocupado por el consumo y por la satisfacción de sus necesidades que por la participación activa en la esfera de los asuntos humanos.

El análisis de Arendt respecto de la política moderna, al menos en el campo de las Ciencias Sociales, ha tomado relevancia en el mundo académico internacional hacia fines del siglo XX y principios del siglo XXI. Quizás este retraso en la lectura de su obra deba entenderse como un recurso de defensa en el pensamiento occidental de posguerra, evidenciado fundamentalmente en las fuertes críticas que recibió su libro Eichmann en Jerusalén. Quizás las heridas del holocausto eran muy recientes para llevar a cabo posicionamientos críticos que no condenaban a los nazis por su demoníaca maldad, sino por haber establecido algo tan sistemático como una burocracia en el uso de la violencia y el exterminio racial. Estas críticas no han sido cuestiones efímeras e irrelevantes, sino que 
perduraron alrededor de la obra de Arendt, como muestra el film titulado Hannah Arendt (dirigido por Margarethe von Trotta en el año 2012). En la película se intenta resaltar la tensión entre los editores y lectores del New Yorker frente al posicionamiento de Arendt, que vincula el mal absoluto del Nacionalsocialismo alemán con la banalidad de un empleado administrativo corriente. Pasados los años, Eichmann en Jerusalén se transformó en una de las marcas teóricas más influyentes de la filósofa en cuestión, puesto que el análisis de lo cotidiano, de lo minimalista -en relación con una política moderna que desvió el camino iniciado originalmente por los griegos- movió el tablero de muchos pensadores que buscaban respuestas en las grandes ideas heredadas del humanismo, descuidando de esa manera el poder que descansa en las acciones más sencillas. Esta ruptura en el ejercicio de la filosofía moderna colabora en la imposibilidad de encasillar a Arendt en una corriente de pensamiento concreta; y esto da cuenta, desde mi punto de vista, de la trascendencia de su obra, vigente incluso en los inicios del siglo XXI. 


\section{Introducción}

Es clave entender el contexto inmediatamente posterior a la segunda Guerra Mundial durante el cual escribió Hannah Arendt, puesto que lo acontecido en los campos de concentración socavó para siempre la idea de progreso vinculada a la ciencia y al humanismo. Las atrocidades llevadas a cabo por los totalitarismos del siglo XX pusieron en cuestión la creencia en la naturaleza como algo ajeno y externo a la existencia del ser humano. La naturaleza sirvió a los nazis en su intento - muy exitoso por cierto- de aniquilar al pueblo judío mediante su deshumanización. Lo natural al alcance del hombre sirvió para crear procesos naturales que sin los hombres no existirían (Arendt 2014: 251); este discurso fue apropiado por los nazis para legitimar un genocidio con modalidades de ejecución nunca antes vistas en la historia de la humanidad, que implicaban la reducción del ser humano a su animalidad. Así, el carácter radical del mal asociado al nazismo reside en su capacidad para volver a los hombres "especímenes del animal humano", en los que se han tornado irreconocibles las características singulares de la existencia humana (Di Pego 2015: 216).

Es en este contexto que el cuerpo humano cobra mayor importancia en disciplinas como la filosofía y las Ciencias Humanas en general, puesto que la maquinaria de odio llevada a cabo por los nazis creó un tipo de cuerpo a su conveniencia: despojado de toda humanidad y condenado a vivir preocupado, tanto por la satisfacción de sus necesidades vitales más elementales como por las actividades asociadas al trabajo (siempre y cuando la industria bélica los considerara necesarios). En términos de Arendt, la fabricación de cadáveres puso en evidencia la necesidad de explorar los mecanismos a través de los cuales el Nacionalsocialismo alemán ejecutó su política de extermino, cuyo interés fundamental se centraba en la dominación absoluta - ya no mediante la persuasión, sino a través de la violencia y el terror dirigidos directamente hacia el cuerpo de aquellos considerados indignos de pertenecer a la raza dominante "por naturaleza". No era la muerte rápida y sin sentido el principal objetivo de los nazis, ya que ésta se destinaba a las mujeres, ancianos, discapacitados y niños incapaces de trabajar en los campos de concentración. Por el contrario, su objetivo era la degradación del pueblo judío (aunque también de polacos, gitanos, homosexuales, comunistas, testigos de Jehová, enfermos mentales y 
discapacitados) a vivir subsumidos a su más primitiva animalidad, condenándolos al padecimiento su labor a través de la utilización de instrumentos como la tortura, la amenaza, la experimentación y la ejecución. La muerte se vuelve una muerte no humana; incluso ante la necesidad de disminuir la población en los campos, "la dominación total" implicaba el avasallamiento de las personas antes de eliminarlas, de modo que no fuese posible reconocer nada humano.

Este interés de los nazis por controlar la naturaleza humana es, a mi entender, uno de los temas más detalladamente relevados en la obra de Arendt, y, con más énfasis, en los últimos apartados de Los orígenes del totalitarismo. La filósofa develó el interés de los Nacionalsocialistas por deshumanizar a los prisioneros judíos, intentando convencerse y convencerlos, mediante el uso sistemático y burocrático de la violencia, de su naturaleza distinta (respecto de una supuesta naturaleza aria destinada a ejercer el dominio total). En pocas palabras, podría afirmarse que los regímenes totalitarios pretendieron modificar la naturaleza humana y terminaron mostrando precisamente que no hay algo así como una naturaleza humana que pueda resultar inalienable:

La falacia trágica de todas estas profecías, originadas en un mundo que todavía era seguro, consistió en suponer que existía algo semejante a una naturaleza humana establecida para siempre, en identificar a esta naturaleza humana con la Historia y en declarar así que la idea de dominación total era no sólo inhumana, sino también irrealista. Mientras tanto, hemos aprendido que el poder del hombre es tan grande que realmente puede ser lo que quiera ser (Arendt 1998: 682).

Los orígenes del totalitarismo es considerada una de las obras más destacadas de Arendt. Originalmente publicada en 1951, el libro se compone de tres volúmenes en los que analiza en profundidad cuestiones relativas al antisemitismo, al imperialismo y al totalitarismo. El último apartado es de particular interés para el desarrollo del presente trabajo, ya que en esas líneas la autora indaga en los métodos llevados a cabo por los nazis para ejercer una forma de dominio total sobre los cuerpos de aquellos sujetos hechos prisioneros.

En 1958, tras dejar su condición de apátrida y obtener la nacionalidad norteamericana, Arendt publica La condición humana; en esta obra no sólo continúa sus reflexiones respecto de los totalitarismos, ${ }^{1}$ sino que también lleva a cabo un análisis

\footnotetext{
${ }^{1}$ A pesar de que Agamben, en su libro El homo sacer. El poder soberano y la nuda vida, afirme que Arendt interrumpe sus investigaciones respecto de los totalitarismos en La condición humana, coincido con Di Pego
} 
pormenorizado de las actividades enmarcadas bajo el concepto de vita activa. Sin embargo, reducir la obra de Arendt a sus estudios sobre los totalitarismos o el Nacionalsocialismo alemán sería desconocer gran parte de sus intereses teóricos. Desde mi punto de vista, a partir de las publicaciones de La Condición humana y, posteriormente, Entre el pasado y el futuro, es posible entrever un interés de la autora por analizar problemáticas contemporáneas a la época (mediados del siglo XX), tarea llevada a cabo sin desatender los temas clásicos de la filosofía política, lo que la obligó a revisar permanentemente diversas cuestiones vinculadas a la política clásica -con particular interés en los escritos de Platón-. Si bien nunca abandonó la revisión permanente respecto de los totalitarismos y de los fenómenos socio-históricos vinculados a dicho movimiento político, con la publicación de estos libros Arendt comienza a analizar cuestiones como las actividades humanas, las crisis de la modernidad, el poder, la violencia, el racismo en Estados Unidos, la educación, la cultura y la noción de autoridad, entre otros temas pertinentes.

La condición humana inicia con un análisis de la ambivalencia de la actividad humana. Por un lado está la vida contemplativa (vita contemplativa), lugar de dominio del pensamiento, la voluntad y el juicio, que parte del ideal griego de contemplación que, como en Aristóteles, no era posible sin el abandono del esfuerzo físico, de la penosa laboriosidad de la corporalidad humana (Tapia Navarro 2008: 135-136). El otro conjunto de actividades humanas pertenece a la vita activa, y se compone de la labor, el trabajo y la acción. Son la inquietud y la actividad, el esfuerzo y la inventiva, la producción y la cosificación, la reificación, los que permiten la construcción de un ambiente propio, artificial y cultural en el cual el hombre se mueve con facilidad dada su cotidianeidad (Tapia Navarro 2008: 136). Esta obra es también fundamental para el presente trabajo, puesto que aborda el concepto de cuerpo en reiteradas ocasiones.

En esta línea de análisis, es importante aclarar que desde el punto de vista de Arendt la naturaleza del cuerpo humano no sería algo inerte, ni una materia factible de analizar en una mesa de disección, tampoco sería algo presente en el reino animal (en esto la autora coincide con Husserl), o sencillamente rastreable en el mundo de la biología. Muy lejos de esta concepción, no sería posible hallar algo así como una naturaleza humana inalienable,

cuando aclara que "existe una estrecha vinculación entre los desarrollos de Los orígenes del totalitarismo y La condición humana" (Di Pego 2010: 64). Este vínculo quedaría explícito en los análisis relativos al ascenso de lo social y al triunfo del animal laborans en la Época Moderna. 
lo humano se encontraría fuertemente atado al orden político imperante, de manera que toda posibilidad de acción, de participación activa con el mundo no es otra cosa que, justamente, una posibilidad. Este vínculo entre las actividades cotidianas y el análisis histórico-político ubica a Arendt como una de las primeras analistas de la biopolítica incluso cuando el término se popularizará recién en la década de 1970, a partir de la obra de Foucault.

Si bien la biopolítica no es un tema central en la presente tesis, no podemos dejar de mencionar algunas cuestiones relativas al interés de la política moderna por el dominio del cuerpo humano. "Es el propio Agamben, quien resalta el advenimiento de la política en biopolítica a partir de la lectura de La condición humana" (Di Pego 2015: 235), particularmente respecto de un modo de "hacer" política asociado al control de la vida. Si bien se suele asociar el concepto de biopolítica con la exaltación del animal laborans en La condición humana, Di Pego (2010) remonta el tema a Los orígenes del totalitarismo. En este sentido, la vida en los campos de concentración conformaría el ejemplo más radical en el ejercicio de la biopolítica; el nazismo puso en práctica una concepción puramente orgánica del ser humano, reduciéndolo a sus propiedades biológicas y despojándolo de toda posibilidad de acción. "La antigua bestialidad espontánea dio paso a una destrucción absolutamente fría y sistemática de los cuerpos humanos, calculada para destruir la dignidad humana. La muerte se evitaba o se posponía indefinidamente" (Arendt 1998: 680). En el segundo capítulo se tratará este tema en profundidad.

A esta altura, resulta relevante atender a los aportes de Crisorio (2015) referentes a la biologización de lo humano como una de las características fundamentales de la sociedad moderna. A modo de antecedentes pertinentes a la confección del presente trabajo, su propuesta de desplazar el cuerpo "natural" e interpretarlo en relación a una construcción social -ubicándolo en medio de las luchas históricas y políticas por la apropiación de "su naturaleza"- resulta clave para profundizar en la noción cuerpo y su vínculo con la política. Esta supuesta naturaleza del cuerpo asociada a un origen esencial, supone también un modo único de interpretar el cuerpo, de estudiarlo, de tomarlo por objeto, considerándolo como "perteneciente a la naturaleza en cuanto universo, (...) fundamental, constante, como si tuviera un modo de ser que le es propio y que hay que conocer tal como efectiva y naturalmente es" (Crisorio 2014: 168). Cabe destacar que la interpretación construida por 
Crisorio no niega el cuerpo sustancial que la fisiología toma por objeto, más bien lo traslada a una dimensión socio-política mucho más amplia y diversificada, ubicándolo como una construcción particular de una disciplina particular, producida con las herramientas generales de la ciencia moderna. Es en este sentido que el cuerpo toma su significado de la disciplina que lo estudia conforme a un momento histórico determinado. Por lo tanto sería ilógico, siguiendo las reflexiones de Crisorio, asignar un origen esencial al cuerpo humano. Toda interpretación conlleva una intencionalidad política; no habría entonces un concepto único de cuerpo, sino un cuerpo sujeto a las teorías que intentan tomarlo por objeto. Por esto nos encontramos en condiciones de afirmar que el cuerpo de las Ciencias Naturales no es similar al cuerpo de las Ciencias Sociales, o, en términos disciplinares más específicos: el cuerpo de la anatomía no es igual al de la sociología, ni similar al cuerpo de la política (comúnmente vinculado a la noción de biopolítica) y mucho menos al cuerpo de la historia, etcétera.

Asociar el término "naturaleza" al término "cuerpo" sólo estaría reduciendo la mirada a sus características biológicas; este reduccionismo a sus necesidades vitales, que Arendt agrupa bajo la noción de labor, sólo conformaría una parte de lo humano. Limitar la existencia del hombre a estas demandas biológicas sería despojarlo de aquello que nos caracteriza como seres distintos al resto de las especies y nos distingue al mismo tiempo de otros seres humanos. El ejercicio de la libertad -asociado en el discurso de Arendt al concepto de acción- es nuestra posibilidad de participar activamente, a través de la palabra y el acto, en la esfera de los asuntos humanos. Cuando indagamos en la intención de los nazis por deshumanizar a los prisioneros de los campos, podemos observar que el objetivo era, justamente, despojarlos de su posibilidad de intervenir activamente en el mundo. Al coartar sus libertades y reducirlos a su existencia animal, los Nacionalsocialistas alemanes crearon un modelo de cuerpo deshumanizado, con la atención vuelta sobre sí mismo (intentando satisfacer las propias necesidades vitales), y justificando una idea de naturaleza puesta al servicio de sus intereses beligerantes.

Si bien Arendt dedica varios pasajes al concepto de cuerpo a lo largo de $L a$ condición humana (con mayor frecuencia a la hora de describir las actividades agrupadas bajo las nociones de labor y trabajo), no lo aborda de manera exclusiva en un libro o capítulo de libro. A este respecto, es importante señalar que recién a comienzos del siglo 
XX, fundamentalmente a partir de los aportes de Husserl y su propuesta fenomenológica, el concepto de cuerpo ingresa progresivamente en el paradigma interpretativo. ${ }^{2}$ La minuciosa problematización respecto al cuerpo y los fundamentos encontrados en las Ciencias Naturales para su estudio resultan un punto de partida histórico en este sentido. El primer capítulo recorre brevemente estas cuestiones, adentrándose en el análisis de algunos ensayos de Husserl y en las influencias rastreables en algunas obras de Arendt.

Un segundo momento en el estudio del cuerpo humano como categoría social podría hallarse en la publicación de Dialéctica de la ilustración. Escrito en 1944 por Adorno y Horkheimer (miembros fundadores de la Escuela de Frankfurt), ${ }^{3}$ en este libro el concepto de cuerpo es vinculado a una interpretación social y ligado a lo histórico-político. Estas investigaciones, contemporáneas a las de Arendt, lograron que de manera progresiva y cautelosa se comience a hablar sobre el cuerpo en la esfera de lo social, academizándolo en diversas ramas de las Ciencias Humanas como la filosofía, la sociología y la psicología. Sin embargo, recién a partir de las obras de Foucault y Bourdieu, publicadas hacia la segunda mitad del siglo XX, podemos afirmar que el concepto de cuerpo, interpretado como construcción social, adquirió la relevancia internacional necesaria para enmarcarse como

\footnotetext{
${ }^{2}$ El paradigma interpretativo radica en la necesidad de comprender el sentido de la acción social en el contexto del mundo de la vida y desde la perspectiva de los participantes. Según Vasilachis, sus cuatro supuestos básicos se vinculan, específicamente, con la consideración del lenguaje como un recurso y como una creación, como una forma de reproducción y de producción del mundo social. Estos supuestos son los siguientes: a) la resistencia a la naturalización del mundo real; b) la relevancia del contexto en el que se dan los procesos de entendimiento; c) la comprensión de la realidad simbólicamente estructurada; d) la doble hermenéutica, es decir, los conceptos de segundo grado creados por los investigadores para reinterpretar diversas situaciones. (2013: 48-49). Este paradigma también puede encontrarse con los siguientes nombres: enfoque interpretativo, tradición hermenéutica y constructivismo, entre otros (Monteagudo 2000: 228).

${ }^{3}$ Los análisis de Arendt y de la Escuela de Frankfurt, particularmente la obra de Adorno, coinciden en varios aspectos. Entre estos se destacan: las influencias de Heidegger, el interés por el revisionismo de la política griega, la historia del pueblo Judío y la crítica al antisemitismo alemán. Además de compartir varios temas de interés común, ambos debieron sufrir la persecución de los nazis, tuvieron que batallar contra la censura de sus obras y se vieron en la necesidad de migrar a los Estados Unidos; esto nos llevaría a creer que sus carreras académicas fueron similares, aunque hayan tomado caminos separados. Estas trayectorias simultáneas pero independientes encuentran sus diferencias en un supuesto resentimiento de Arendt hacia Adorno, debido entre otras cosas a la negación por parte del filósofo frankfurtiano a aprobar la tesis de habilitación de su primer esposo. Según Zamora: "Arendt achacaba a Adorno el fracaso del intento de habilitación académica de su primer marido Günter Anders, y consideraba inaceptable e irritante el trato que según ella recibía Walter Benjamin en el exilio francés (de parte de Instituto de Investigación Social en Nueva York). Su suspicacia frente a lo que éstos pudieran hacer con los manuscritos de Benjamin, entre ellos el texto con las Tesis sobre el concepto de historia, que la propia Arendt debió entregar a Adorno por encargo expreso de su autor, su denuncia en el periódico estudiantil Diskurs de los supuestos intentos de Adorno de adaptación a la Alemania nazi como crítico musical antes de su exilio, la controversia en torno a la primera edición de las obras de Benjamin, que motivó su única correspondencia conocida, y la acusación a Adorno de urdir campañas difamatorias contra su maestro Heidegger, son algunos de los episodios de esta historia de desencuentros". (Zamora 2010: 245-246).
} 
problema de investigación más vinculado a la historia y la política que al tradicional mundo de las Ciencias Naturales. No obstante, pareciera que Arendt dejó las puertas abiertas a una relectura de su obra en relación a una interpretación social del cuerpo. Esta afirmación, ciertamente personal, se basa en la idea propuesta por Arendt en su libro Entre el pasado y el futuro, de abrir una brecha (en términos metodológicos) entre el pasado y el futuro para reflexionar críticamente respecto de nuestro presente. Esta es justamente la metodología propuesta a lo largo de esta tesis, reflexionar respecto del cuerpo y la naturaleza como construcciones sociales, con particular atención en la segunda mitad del siglo XX, y a partir de una lectura detallada de la obra de Hannah Arendt.

Las obras seleccionadas para llevar a cabo la tarea de investigación mencionada anteriormente son (en orden según los años originales de su publicación): Los orígenes del totalitarismo [1951], La condición humana [1958], Reflections on Little Rock [1959], Entre el pasado y el futuro [1961], Eichmann en Jerusalén [1963], Sobre la violencia [1969-1970] y De la historia a la acción [1995]. De modo sintético, el objetivo de la tesis radica en indagar el contenido de estas obras, en relación al análisis de las nociones cuerpo y naturaleza como conceptos vinculados a la esfera de los asuntos humanos. La propuesta de análisis supone una atención particular respecto del concepto de cuerpo, desde un abordaje alternativo al tradicional enfoque biologicista que lo reduce a un conjunto de huesos, articulaciones y músculos. Nos encontramos así frente a la posibilidad de llevar a cabo una serie de indagaciones -las cuales están expuestas a interpretaciones arriesgadas y erróneas-que trascienden por completo el reduccionismo de un cuerpo ligado a la interpretación de las Ciencias Naturales. ${ }^{4}$ Hecha la aclaración respecto de la mirada histórica-hermenéutica en que se contextualizan las nociones de cuerpo y naturaleza, es necesario ahora explicitar las hipótesis que recorren el presente trabajo.

La primera hipótesis supone en la teoría de Arendt una noción de cuerpo que trasciende la mera explicación biológica del humano como un animal reducido a la

\footnotetext{
${ }^{4}$ Considero positivismo al monismo científico-metodológico, esto es, la pretensión de un método universal que toma el patrón establecido por las Ciencias Naturales y exactas como ideal regulador, único y supremo de la comprensión racional de la realidad (Von Wright 1979: 25). Este paradigma tiene su apogeo a mediados del siglo XIX y comienzos del siglo XX, influenciando no sólo el modo de investigar en las Ciencias Naturales, sino también el de las Ciencias Sociales. Siguiendo a Vasilachis, el positivismo aplicado a la investigación social cuenta con ciertos presupuestos que lo distinguen de otros paradigmas: "a) la observación exterior de los fenómenos sociales, b) las leyes sociales como expresión de regularidades, c) las explicaciones causales, y d) la verificabilidad y/o refutabilidad de las teorías" (Vasilachis 2013: 48).
} 
satisfacción de sus necesidades. En sus escritos se evidencia el cuerpo atravesado por sus funciones vitales, al mismo tiempo que advierte sobre la peligrosidad del reduccionismo a estas labores. La participación activa del hombre en el mundo requiere de un cuerpo disponible y liberado de la atención sobre sí mismo, lo que no significa que se deba denigrar a la labor. En este contexto, la tesis se propone llevar a cabo una minuciosa lectura de La condición humana, afirmando que esta obra intenta dignificar académicamente las actividades más sencillas y mundanas del ser humano, analizando el lugar que ocupan dentro de una jerarquía simbólica, denominada por Arendt como vita activa.

De la afirmación anterior, por la que el cuerpo es concebido en la teoría de Arendt como algo ligado a la esfera de los asuntos humanos, se desprende una segunda hipótesis. En pocas palabras, esta supone que toda idea de naturaleza que se intente imponer como modeladora del cuerpo humano no es otra cosa que una construcción, justamente humana, producto del consenso y del posicionamiento histórico-político. A diferencia de la interpretación que prevalece en occidente moderno, la cual descansa en la explicación biológica de cuerpo inerte, muerto, fragmentado, la interpretación de la obra de Arendt, ligada a "lo político", nos invita a reflexionar sobre un cuerpo activo, digno de analizar a partir de lo que hacemos cotidianamente. Esta cercanía del análisis histórico político con las actividades más mundanas del hombre, ubica al cuerpo en un lugar de acción permanente, cuyos actos y consecuencias, imposibles de predecir y en estrecha relación con el ejercicio de la libertad, nos condicionan como humanos, al mismo tiempo que nos ofrecen una infinita posibilidad de participación activa con el mundo.

Las obras de Arendt mencionadas anteriormente serán analizadas en relación a cuatro problemáticas fundamentales. En primer lugar, se desarrollará un breve acercamiento al concepto de cuerpo y naturaleza en la perspectiva de Husserl. Esta decisión se basa en los aportes del filósofo a la hora de problematizar al cuerpo vinculado a las Ciencias del Espíritu, ${ }^{5}$ asumiendo que la búsqueda de facticidades, propia del positivismo

\footnotetext{
${ }^{5}$ Cuando Husserl habla de las "Ciencias del Espíritu" hace referencia a lo que hoy conocemos como "Ciencias Humanas". Uno de los problemas principales que desarrolla el filósofo alrededor de este campo es la permeabilidad hacia el positivismo que mostró hacia principios del siglo XX. Lejos de tratarse de un problema menor, Husserl afirma que la crisis de Europa (evidenciada en el estallido de la Primera Guerra Mundial) encuentra su origen en esta invasión científico-positivista sobre cuestiones específicamente humanas. Aclara Quiroz Espina: "el modo por el que se logró conocer la naturaleza quiso ser llevado al ámbito de lo espiritual (...), todos los fenómenos sociales se pusieron sobre la base de un cuerpo físico
} 
científico, carece de vinculación alguna con lo esencialmente humano. En segundo lugar, la tesis recorre las nociones de cuerpo y naturaleza a lo largo de los tres conjuntos de actividades que se enmarcan bajo la noción de vita activa: la labor, el trabajo y la acción. En tercer término, la mirada estará puesta en la educación y la forma en que esta institución ignoró históricamente al cuerpo en términos histórico-políticos, relegándolo a un segundo plano, al reducirlo al hacer del trabajo y asociarlo al discurso biologicista que lo toma por objeto de laboratorio. En relación al campo de la educación, podemos apreciar una naturalización del cuerpo asociado al saber de la biología y un relegamiento a un segundo plano respecto a las asignaturas "intelectuales". Estas ubicarían al pensamiento sobre la acción, basándose en una disociación políticamente intencionada entre cuerpo y mente cuyos orígenes pueden hallarse en la política griega entendida en términos de Platón, es decir, concibiendo al cuerpo como "cárcel del alma".

Por último, pretendo analizar el cuerpo como medio y fin de la violencia, esto es, indagar de qué manera el cuerpo puede convertirse en arma, como así también en el destino de la violencia (aquí me centraré fundamentalmente en la violencia institucional, y en los medios llevados a cabo por organizaciones políticas asociadas al totalitarismo). Con respecto a la violencia, no podemos perder de vista la noción moderna que asocia la política con el hacer (situación evidenciada en las revoluciones armadas que dieron lugar a las fundaciones de los actuales Estados modernos). Vincular la política con el hacer, como si fuese posible hallar la política en un estado natural, ubica peligrosamente a "la fabricación" a la misma altura de los asuntos humanos. Si la política se hace, el medio más efectivo para llevarla a cabo es la violencia (al igual que el medio más efectivo para la destrucción de la naturaleza requiere de la violencia asociada a la extracción, la fragmentación, la producción, etcétera); ésta traslación de "lo productivo" a la esfera de los asuntos humanos admite el uso de la violencia, al igual que el trabajo lo admite para el control de la naturaleza. Este traslado de la naturaleza "salvaje" al mundo social de la política justificaría el empleo de medios riesgosamente efectivos para ejercer el dominio. Al pretender hacer política con los medios del trabajo, el cuerpo se transforma en un medio más, actuando 
como depositario y reproductor de la violencia, según el lugar que ocupe en determinado contexto histórico.

El presente trabajo, en definitiva, sencillamente intenta poner a disposición algunas herramientas conceptuales de la perspectiva de Arendt. Cabe aclarar que el lector no se encontrará con una obra concluyente; más bien, se encontrará con una serie de problemas irresueltos, puesto que los temas desarrollados en las obras de la autora en cuestión, nos afectan directamente como sujetos del mundo moderno. 


\section{Metodología}

Este apartado tiene como objetivo describir los pasos llevados a cabo y las dificultades encontradas a lo largo del registro de las obras de Arendt. Como primera aclaración, es importante destacar que la tesis incluye un abordaje metodológico de carácter históricohermenéutico basado en la revisión documental, con particular atención respecto de la autora señalada y de sus obras vinculadas a los conceptos de cuerpo y naturaleza; para realizar esta tarea, se llevó a cabo una serie de análisis detallados de libros, capítulos de libros, artículos de revistas científicas y recursos audiovisuales, tanto de fuentes primarias como secundarias. Como segunda aclaración, hay que señalar que no todas las obras de Arendt publicadas fueron relevadas -el material registrado se detalla en el apartado referente a la bibliografía- .

Desde el punto de vista etnográfico, la tesis no pretende incluir un "trabajo de campo", esta decisión es resultado de los recaudos teóricos necesarios para no "hacer decir" a Arendt cuestiones que no pretendió abordar. Incluso cuando temas como cuerpo, naturaleza, política, educación y violencia difícilmente puedan escapar a las problemáticas más recurrentes de los últimos tiempos en occidente, la propuesta para la lectura de Arendt se recorta en la búsqueda de herramientas conceptuales que nos ayuden a interpretar nuestro presente, y no a buscar soluciones mágicas.

Además de las aclaraciones mencionadas, corresponde a este apartado la explicación respecto del apego teórico-metodológico en relación con los escritos de Arendt. En esta línea de análisis, "la teoría" es interpretada en el sentido que le otorga Archenti en Metodología de las ciencias sociales. En sus propias palabras:

Si bien toda definición es arbitraria y relativa al contexto de su elaboración, el problema en este caso particular es la coincidencia entre el concepto a definir y el contexto definitorio. [...] Existen múltiples definiciones de teoría cuya arbitrariedad sólo está limitada por el contexto teórico que las contiene, de tal modo que adherir a una definición supone ya la adhesión a una teoría previa (Archenti 2007: 61).

Adherir a la "definición" anteriormente citada, en el contexto del presente trabajo, es asumir la adhesión al pensamiento de un autor (en este caso particular, el pensamiento de Arendt). Esto implica admitir que la especificidad metodológica, entendida en términos 
tradicionales-positivistas, no constituye una de las principales preocupaciones desarrolladas por la filósofa en cuestión. Por el contrario, sus obras están cargadas de subjetividad y comentarios personales, más vinculados con el ejercicio de una permanente revisión histórica, debidamente justificada, que con una fundamentación etnográfica o con la pretensión de verdad universal. Al respecto aclara Di Pego:

Las dificultades que enfrenta Arendt en la comprensión del totalitarismo, la confrontan a su vez con la reflexión sobre la tarea de la historia y de las Ciencias Sociales. En este contexto, Arendt no sólo lleva a cabo una crítica del paradigma científico imperante hacia mediados del siglo pasado, sino que también procura pensar estas actividades dentro de un nuevo marco conceptual que desafía a ese paradigma vigente. De este modo, en discusión con las interpretaciones que sostienen que Arendt carece de método, pretendemos mostrar, no tanto que procede según un método, sino que más bien procede según pautas y criterios que obran como marcos orientadores -narración discontinua, imaginación, singularidad, sentido- y que su concepción implica un posicionamiento epistemológico singular en el que se produce un desplazamiento de los conceptos de ciencia, objetividad y causalidad, por los de comprensión, imparcialidad y cristalización. (Di Pego 2013: 19-20).

Esta forma de encarar sus investigaciones puso a Arendt en el centro de la crítica en reiteradas ocasiones, sobre todo en relación a la publicación de Eichmann en Jerusalén. Cuando Arendt describe a Eichmann como un hombre corriente, capaz de llevar a cabo una vida similar a la de cualquier trabajador, y reinterpreta la maldad del funcionario nazi comúnmente asociado a lo demoníaco, a lo mefistofélico- a la figura de un simple funcionario, expone sus reflexiones en relación a cuestiones muy delicadas a su época (como el análisis del totalitarismo y la descripción de la vida en los campos). ${ }^{1}$

Esta modalidad de narración que vincula permanente la revisión histórica con el ejercicio de la reflexión -legitimada a partir de un constante allanamiento del pasado en el que intenta reflotar los sentidos originales de la sociedad occidental, recurriendo frecuentemente a diversos registros grecorromanos-, es una de las marcas teóricas más relevantes en la obra de Arendt.

\footnotetext{
${ }^{1}$ En Eichmann en Jerusalén, Arendt desarrolla las cuestiones de "lo corriente" y "la maldad" asociadas a las tareas desempeñadas por Eichmann como funcionario del partido Nazi. En este sentido, una breve cita sirve para aclarar lo mencionado: "Aparentemente más complicada, pero en realidad mucho más simple que el examen de la interdependencia entre la irreflexión y la maldad, es la cuestión referente al tipo de delito cometido por Eichmann, un delito unánimemente considerado sin precedentes. El concepto de genocidio, acuñado con el explícito propósito de tipificar un delito anteriormente desconocido, aun cuando es aplicable al caso de Eichmann, no es suficiente para abarcarlo en su totalidad, debido a la simple razón de que el asesinato masivo de pueblos enteros no carece de precedentes. La expresión «matanzas administrativas» parece más conveniente" (Arendt 1999: 273).
} 
Hablar de la obra de Arendt, es hablar de la importancia que tiene el criterio propio, el pensamiento, la reflexión. Es por esto que una crítica, enmarcada en los principios positivistas, respecto de la subjetividad que conlleva su obra, es una crítica a su impronta personal y, por lo tanto, al sello que la ubica en diversos campos de la filosofía política como una de las autoras más influyentes del siglo XX. Si bien su criterio y sus opiniones son debatibles, no podemos desacreditar los aportes de la autora respecto de lo imprescindible que resulta el pensamiento propio en la vida del hombre moderno. Este es el recorrido por el que el hombre de la modernidad, dominado, sujetado, dependiente de las políticas estatales, puede iniciar el camino hacia la verdad, interpretada en la lógica arendtiana como el ejercicio de la revelación, ${ }^{2}$ del entendimiento de los procesos históricopolíticos que lo rodean. Desenmascarar las redes de dominación, los usos de la violencia y de la dominación despótica, del control totalitario, son algunos de los desafíos que Arendt propone llevar a cabo a través del sencillo y al mismo tiempo liberador ejercicio del pensamiento reflexivo.

\footnotetext{
${ }^{2}$ Cabe destacar que Arendt rechaza el concepto de verdad entendido como un modo inactivo de aceptación de la realidad. En este sentido, la verdad y sus efectos podrían analizarse en relación a su poder totalizador, puesto que al aceptar pasivamente una verdad, estaríamos confirmando nuestra despreocupación con respecto a la misma, ubicando a "la verdad" en un lugar peligrosamente hegemónico. En sus propios términos: "Si la principal característica de las ideologías fue tratar una hipótesis científica, por ejemplo, la supervivencia del más fuerte en biología o la supervivencia de la clase progresista en la historia, como una «idea» que podía ser aplicada a todo el curso de los acontecimientos, entonces es propio de su transformación totalitaria el pervertir la «idea» en una premisa en el sentido lógico, esto es, en algún enunciado autoevidente a partir del cual todo lo demás puede deducirse con implacable coherencia lógica. (...) Esta ecuación implica, de hecho, la negación de la existencia de la verdad, en tanto que se suponga que la verdad es siempre revelación, mientras que la coherencia es solamente un modo de encadenar enunciados y, como tal, le falta poder revelador" (Arendt 2005: 39-40).
} 


\section{Capítulo 1. La alternativa al positivismo como punto de partida}

Si el mundo fuera un edificio de dos esferas de realidad, naturaleza y espíritu, con igualdad de derechos, por decirlo así, ninguna favorecida metodológica y objetivamente con respecto a la otra, entonces la situación sería distinta. Pero sólo la naturaleza puede ser tratada de por sí como un mundo cerrado, sólo la ciencia de la naturaleza puede, con inquebrantada consecuencia, abstraer de todo lo espiritual e investigar la naturaleza puramente como naturaleza.

(Husserl, E. Invitación a la fenomenología).

\subsection{Discusiones en torno a la fenomenología de Edmund Husserl y su relación con el pensamiento de Hannah Arendt}

Tomaremos como punto de partida la fenomenología de Husserl, y particularmente sus reflexiones en torno al cuerpo humano, el movimiento y la Tierra, ya que su obra resulta determinante tanto para el pensamiento de Heidegger como para el de Arendt. Si bien existen varias hipótesis con respecto a la influencia de Husserl sobre la filósofa en cuestión, las cuales se encuentran explícitas en diversas biografías, los aportes de Serrano de Haro (2008) resultan esclarecedores al respecto:

La biografía de Arendt firmada por su antigua alumna Elisabeth Young sí sostiene, con laconismo, que la joven estudiante se trasladó a Friburgo inmediatamente después de tener que abandonar Marburgo y que residió allí durante el semestre de invierno 1925-1926 (Serrano de Haro 2008: 300).

Por lo tanto, la estancia de Arendt coincide con la función de Husserl como profesor en la universidad de Friburgo.

Si bien en la obra de Arendt no es posible hallar referencias explícitas al tema del cuerpo desde la perspectiva de Husserl, no podemos desconocer la influencia del filósofo moravo en el campo de la Filosofía y las Ciencias Humanas; particularmente centrando la atención respecto a la problematización del cuerpo como categoría inherente a lo social. En este contexto, Serrano de Haro (2008) lleva a cabo una lectura posible respecto de la influencia de Husserl en el pensamiento de Arendt que vale la pena destacar: "Resulta imprescindible el contraste del enfoque de Arendt con la exploración husserliana de la receptividad intuitiva y de la pasividad sensible, es decir, de la experiencia del cuerpo propio y de la conciencia interna del tiempo" (Serrano de Haro 2008: 302). 
Los aportes de Husserl resultan de fundamental importancia si queremos llevar a cabo una minuciosa lectura del cuerpo y de su origen teórico, ligado tanto al campo de las Ciencias Naturales como al campo de las Ciencias Sociales. El análisis de esta relación resulta completamente necesario para problematizar el cuerpo e indagar su vinculación con lo que Husserl denomina las Ciencias del Espíritu. La teoría trascendental del conocimiento científico-natural, desarrollada por Husserl en su ensayo titulado La tierra no se mueve, resulta esclarecedora a la hora de fundamentar el concepto de cuerpo como objeto de interés científico. Para el filósofo, la ciencia dedicada al estudio de hechos o realidades naturales se encuentra distanciada de las Ciencias del Espíritu, lo que ubica al cuerpo humano en medio de diversas tradiciones de pensamiento. Con un marcado rechazo al positivismo, ${ }^{1}$ él indaga en las bases de la ciencia tradicional y pone en cuestión la universalización de su discurso. Esta posición crítica en lo referente al conocimiento científico sirve para pensar el reduccionismo del cuerpo como mero objeto de análisis.

Siguiendo la fenomenología husserliana, al ubicar el cuerpo humano a la par de otros objetos típicos del campo de las Ciencias Naturales no estaríamos haciendo otra cosa que deshacernos de su esencia original, basada fundamentalmente en el uso de los sentidos y la experiencia. Interpretar el cuerpo en la lógica del positivismo equivale a materializar un discurso que imposibilita cualquier experiencia genuina o pura; la fenomenología husserliana, por lo tanto, encuentra al positivismo y a su expansión universal como un enemigo en la tarea interpretativa. De la mano del método científico, el cuerpo puede ser problematizado a la par de otros objetos tan diversos como los campos disciplinares en los que fueron pensados. Al afirmar que la "tierra se mueve", que "rota", que "es un cuerpo entre otros cuerpos" ¿no estamos acaso extendiendo las propiedades del cuerpo humano al suelo que pisamos y, por añadidura, al universo que nos rodea? ¿Es esta supuesta conexión algo natural e inevitable? ¿Acaso la ciencia, y particularmente la Ciencia Natural, se apropió de algo que estuvo allí siempre? ¿Por qué las Ciencias Naturales, y no otras, fueron las encargadas a partir de la modernidad de hallar explicaciones a fenómenos tan diversos como el cuerpo humano, la tierra y el cosmos? Estas son algunas de las cuestiones que atraviesan la lectura del ensayo de Husserl mencionado anteriormente, y a partir de las

\footnotetext{
${ }^{1}$ El peligro del positivismo, para Husserl, radica en un problema epistemológico y ético: la naturalización de la esfera espiritual del hombre ha hecho que pierda el rumbo de lo que él llama su "tarea infinita", la creación constante de ideas acerca de sí mismo y del mundo en el que se mueve (Quiroz Ospina 2015: 118).
} 
cuales se establece un punto de partida histórico para la realización del presente trabajo. Las reflexiones respecto al lugar que ocupa el cuerpo humano en la interpretación del tiempo y del espacio resultan determinantes, no solo para analizar la obra de Arendt en lo concerniente al cuerpo interpretado como algo más allá de la mera existencia física, sino también para comprender el papel del cuerpo en las Ciencias Sociales:

Por más que en la génesis experiencial de nuestra representación del mundo la Tierra sea para nosotros el suelo de la experiencia de todo cuerpo, jasí y todo, ella es también un cuerpo, sin duda! [...]Las representaciones de reposo y de movimiento que hay que atribuir a la tierra, por una parte, y a los astros, por otra, se ven afectadas por el hecho de que la Tierra llegue a tener, en la constitución intencional, valor de cuerpo físico (Husserl 2006: 11-12).

$\mathrm{Al}$ intentar hallar respuestas sobre los modos en que el humano interpreta el mundo que lo rodea, Husserl piensa en la fenomenología como el medio teórico más eficiente para llevar a cabo dicha tarea. El cuerpo adquiere gran importancia en la obra de Husserl puesto que es el portador de los sentidos; la relevancia de estos radicaría en su función mediadora entre la percepción subjetiva y el mundo real. Solo a través de un método capaz de captar los sentidos originales, las esencias de los fenómenos cotidianos, la filosofía será capaz de deshacerse del velo universalista de la verdad positiva. Este ejercicio de una filosofía mundana, revisionista de las acciones cotidianas es una marca evidente en los escritos de Arendt. Esta afirmación se hace particularmente evidente en La condición humana, donde la filósofa se interesa por cuestiones vinculadas a la noción de labor, y analiza aspectos de la vida cotidiana como las formas de comer, de dormir, de vestirse, con una clara intención de revalorizar la reflexión en relación a dichas acciones. Allí, las cuestiones comúnmente consideradas "mundanas" -y deslegitimadas por la filosofía clásica- son ubicadas a la par de diversos acontecimientos histórico-políticos de gran relevancia. Al menos en esta lógica en la que se ubica a la labor como tema digno de análisis, Arendt pone en escena un modo de hacer filosofía que podría vincularse, en términos generales, al análisis de la experiencia humana que propone Husserl. La noción de cuerpo que atraviesa la obra de Arendt citada anteriormente no escapa a esta relación, puesto que es posible hallar una crítica explícita en Arendt más vinculada a una interpretación política de la modernidad- respecto del interés de la ciencia moderna por apropiarse del discurso que explicaría la totalidad de los fenómenos inherentes a la vida humana. Los totalitarismos conforman un claro ejemplo en este sentido. Si bien Husserl muere el mismo año en que Hitler invade Polonia e inicia la 
Segunda Guerra Mundial, podría fácilmente pensarse que la preocupación del filósofo por problematizar cuestiones inherentes al cuerpo humano, se continúa en la preocupación de Arendt, particularmente al analizar la manipulación de la naturaleza humana en manos de la ciencia moderna.

\subsection{Entre lo humano y lo natural ¿Dónde hallar un punto de partida?}

Profundicemos ahora la relación que Husserl establece entre el cuerpo y la Tierra. El autor distingue tres etapas alrededor de la interpretación de la Tierra. En la primera, la misma es interpretada como el suelo a partir del cual se originaría toda experiencia de los cuerpos; suelo del reposo y punto de partida para entender el movimiento, la Tierra no sería considerada un cuerpo, sino más bien un punto estable desde el cual sería posible dar origen a una experiencia. En la segunda, la Tierra ya es un cuerpo, más específicamente un cuerpo universal que envuelve toda experiencia posible. En la tercera, la Tierra se torna un cuerpo más: continúa siendo el punto de partida para el movimiento y el reposo de los cuerpos, pero ella misma se ve afectada por otros cuerpos a los que le asigna valor de referencia. ${ }^{2}$ Este interés de Husserl por hallar un punto de partida desde el cual analizar la experiencia humana queda explicitado del siguiente modo:

Examinemos el movimiento de cuerpos en el marco de la función originariamente intuitiva de la Tierra como suelo; o, dicho de otro modo, los cuerpos concebidos en la originalidad de ser susceptibles de movimiento o cambio efectivos; lanzados hacia arriba, moviéndose como quiera que sea, no sabré hacia dónde, pero sí sé que relativamente a la Tierra, al suelo de la Tierra (Husserl 2006: 14).

La perspectiva de Husserl deja en claro que la forma en que interpretamos la Tierra y los fenómenos que se tejen alrededor de ella resultan de particular relevancia para tratar de interpretarnos a nosotros mismos. Si bien se le podría objetar que el cuerpo humano es más que un cuerpo físico en el espacio desde el que emanan experiencias, no podemos negar que sus reflexiones sirven como punto de anclaje para problematizar el cuerpo humano y los orígenes de su cuestionamiento en el campo del paradigma interpretativo.

\footnotetext{
${ }^{2}$ Una aclaración de Serrano de Haro respecto de las tres etapas que distingue Husserl puede servir para aclarar la cuestión: "La primera etapa desconoce la posibilidad de atribuir a la Tierra la dualidad movimientoreposo; la desconoce no por ignorancia sino por principio, por tratarse de la instancia que da sentido a tal alternativa referida a cuerpo en relación con la Tierra. La segunda etapa tiende a representarse la Tierra en reposo, mientras que la tercera abre ya la posibilidad de concebirla en movimiento" (Serrano de Haro en Husserl 2006:13).
} 
Si bien la Tierra constituiría la base de toda experiencia, desde un punto de vista social, la experiencia humana, vivida en relación a fenómenos históricos trascendentales, puede ser capaz incluso de reinventar los fundamentos de un supuesto orden natural. En esta lógica de análisis, por lo tanto, cabría afirmar que la relación de los hombres con el mundo no sería algo prescrito, algo innato a la biología del humano; por el contrario, estaría sujeto al devenir de diversos procesos histórico-políticos. Una minuciosa lectura del último capítulo de Los orígenes del totalitarismo colabora en la explicación de lo hasta aquí desarrollado. En términos biológicos-naturales, el cuerpo de un oficial de las SS puede ser considerado igual al cuerpo de un prisionero judío, ambos tienen la misma conformación anátomo-fisiológica, los mismos procesos metabólicos y las mismas necesidades nutricionales; sin embargo, durante la Segunda Guerra Mundial, fue el cuerpo del prisionero judío el que permaneció sujeto a una mesa de experimentación. Como si su naturaleza descansara en manos de los Nacionalsocialistas Alemanes y su destino no fuese otro más que ocupar ese lugar. En pocas palabras, la diversificación de matrices conllevaría una posibilidad infinita de cuerpos, ya que la naturaleza desde la que se construye su interpretación se encuentra sujeta al mismo proceso interpretativo. Al respecto, en Los orígenes del totalitarismo, Arendt problematiza sobre el concepto de naturaleza del siguiente modo:

El positivismo y el progresismo del siglo XIX pervirtieron esta finalidad humana cuando trataron de demostrar lo que no puede demostrarse, es decir, que los hombres son iguales por naturaleza y que sólo difieren por la Historia y las circunstancias, de forma tal que pueden sentirse iguales no por los derechos, sino por las circunstancias y la educación. El nacionalismo y su idea de una «misión nacional» pervirtieron el concepto nacional de la Humanidad como una familia de naciones en una estructura jerárquica en donde las diferencias históricas y de organización fueron erróneamente interpretadas como diferencias entre los hombres y que residían en el origen natural de éstos (Arendt 1998: 358).

Husserl, por su parte, y tras analizar la relativa ${ }^{3}$ estabilidad de los cuerpos físicos (interpretados como universales a partir de su composición material y de su condición física), se adentra en el análisis del cuerpo humano y el cuerpo de los animales. Para éstos reserva el concepto de "cuerpos de carne”, cuyas propiedades no sólo serían físicas, sino que, al poseer capacidad de traslación, de actividad, de reposo, tendrían la posibilidad única

\footnotetext{
${ }^{3}$ La relatividad descansaría en la movilidad propia del cuerpo de referencia, se decir que la Tierra, al encontrarse ella misma sujeta a las leyes del movimiento del cosmos, no funcionaría como suelo estable desde el punto de vista estricto de la física teórica.
} 
(en relación a otros cuerpos físicos) de poseer "movimiento propio". Si bien ninguno de estos cuerpos podría desprenderse de la Tierra como "punto cero", sus posibilidades de movimiento conforman posibilidades de experiencias infinitas; las variaciones se encuentran sujetas al origen de las cinestesias (diversidad de especies, hábitats, espacios, etc.). De este modo, el movimiento humano, por ejemplo, puede ser percibido como interno, diferenciándose radicalmente del resto de los cuerpos físicos que habitan la Tierra. Husserl aclara al respecto:

«Mi cuerpo de carne», «otros cuerpos de carne». Estos últimos se perciben como cuerpos físicos en el espacio [...]. Mi cuerpo de carne: en la experiencia primordial, mi cuerpo no se desplaza ni reposa, y únicamente tiene, a diferencia de los cuerpos externos, movimiento interno y reposo interno. Con el «yo ando», en general con el «yo me muevo» cinestésico, no «se mueven» todos los cuerpos físicos, ni se mueve el suelo íntegro de la Tierra que está debajo de mí (Husserl 2006: 29-30).

Husserl juega con diversas interpretaciones en torno al movimiento, la cinestesia, y la posibilidad que poseen otros cuerpos de experimentar distintos tipos de desplazamientos, siempre tomando el suelo de la Tierra como punto de referencia. La Tierra es la misma para todos; sobre la superficie de la Tierra, en la Tierra, por encima de ella, existen para todos los mismos cuerpos físicos; sobre su superficie, en ella, etcétera (Husserl 2006: 33). Tomando la tierra como punto de partida, el autor analiza el vuelo de los pájaros, el movimiento de un vehículo o el ascenso de un aeroplano destacando la imposibilidad de transferir las diversas experiencias entre ellos.

\subsection{La vida biológica y la vida del espíritu}

Para analizar el modo en que históricamente se problematizó la existencia humana, Husserl realiza una distinción entre las Ciencias Naturales y las Ciencias del espíritu. Mientras que el primer grupo se basa en las leyes de la matemática para rastrear cualidades fácticas reproducibles en todos los seres humanos, para los segundos "lo humano" encontraría explicación en su relación con el mundo, y esta no solo no sería reproducible, sino que debe ser estudiada con herramientas metodológicas destinadas a tal fin. Dentro de este segundo grupo estarían involucradas la psicología, la sociología, la antropología y la historia.

El cuerpo humano analizado bajo la perspectiva de las Ciencias Naturales quitaría al hombre toda posibilidad de participación; la capacidad de acción estaría subordinada a un orden lógico y predecible, y lo social no sería otra cosa que, en términos arendtianos, un 
"laborar en conjunto". En la perspectiva de Husserl, toda interpretación que realizamos del mundo es, justamente, una interpretación; es así que "lo humano" condicionará siempre toda búsqueda de facticidades.

La Tierra misma y nosotros los hombres, yo y mi cuerpo, y yo en mi generación, en mi pueblo, etc., toda esta historicidad forma parte inseparable del ego y es por principio irrepetible. Todo lo que es remite más bien a esta historicidad de la constitución trascendental como núcleo ya dado y núcleo que está en ampliación -todo descubrimiento de una nueva posibilidad mundana se liga al sentido del ser que ya está listo- (Husserl 2006: 52).

Frente a la concepción naturalista de la ciencia, la perspectiva husserliana propone incluir la historicidad como principal eje de análisis en lo que respecta a las cuestiones humanas, fundándose en el carácter irrepetible de la historia, lo que le otorgaría cierto grado de esencia, cierto valor de verdad. Arendt, sin embargo, lleva esta cuestión a una interpretación más radical, argumentando que, a la par de la naturaleza, la historia puede ser manipulada a la conveniencia del orden político que así lo demande. Interpretada de este modo, la historia no solo perdería su valor apodíctico -y más particularmente la historia de las ideologías-, sino que quedaría reducida a un medio de coerción ideológico, incluso subordinado al discurso naturalista. En Los orígenes del totalitarismo, Arendt reflexiona en torno al papel de la historia del siguiente modo:

Las ideologías se hallan siempre orientadas hacia la Historia, incluso cuando, como en el caso del racismo, partieron aparentemente de la premisa de la Naturaleza; aquí la Naturaleza sirve simplemente para explicar cuestiones históricas y para reducirlas a cuestiones de la Naturaleza (Arendt 1998: 700).

A pesar de estas discrepancias en relación al valor de verdad de la historia, no podemos dejar de mencionar ciertas continuidades en los dos autores a la hora de conceptualizar el cuerpo humano dentro de este eje de análisis. Es innegable el interés de ambos por estudiar la historia y la naturaleza como matrices determinantes en la constitución de lo humano. A partir de esta lectura, en Husserl más vinculada a la búsqueda de una alternativa fenomenológica, en Arendt más asociada a lo político, no podemos desconocer en ambos el interés por valerse de la historia y la naturaleza como base epistemológica desde la cual sería posible rastrear un marcado rechazo al positivismo.

Retomando el análisis sobre el cuerpo humano y su relación con el mundo, la muerte es un claro ejemplo para entender más en profundidad los posicionamientos teóricos encontrados tanto en Husserl como en Arendt. Al mismo tiempo, estudiar la muerte 
vinculada a la noción de cuerpo, colabora en la interpretación que sostiene las Ciencias Naturales, frente al discurso de las Ciencias del Espíritu.

El cuerpo humano concebido en términos naturales considera a la muerte simplemente como la finalización de un ciclo biológico, no habría nada más detrás del finito proceso anátomo-fisiológico que da lugar a la vida. Muy por el contrario, una perspectiva interpretativa, más ligada a lo que Husserl denomina las Ciencias del Espíritu, vería en la muerte la necesidad de recrear la experiencia humana a partir del empleo de otros recursos ligados a la vida en sociedad. En esta lógica, la vida de una persona y sus experiencias no necesariamente desaparecen con la muerte física, ya que pueden ser invocadas a partir del recuerdo de una familia, una generación, un pueblo, trascendiendo de esta manera el reduccionismo animal que conlleva la muerte biológica. En términos de Husserl:

Yo como presente existo en un continuado morir; y para mí los otros mueren cuando ya no encuentro la trama presente de relaciones con ellos. Pero la unidad de rememoración atraviesa mi vida -todavía vivo y sigo viviendo la vida que queda a mi espalda, bien que lo hago en un modo de ser distinto, cuyo sentido de «a mi espalda» descansa en la repetición y en la repetibilidad-. [...] Mientras el individuo muere, es decir: a él ya no se le puede recordar en la empatía, sino sólo en un recuerdo histórico que los sujetos recordados delegan en otros (Husserl 2006: 55-56). ${ }^{4}$

Husserl pone así el acento en el "recuerdo histórico" como posibilidad de rescatar la experiencia humana más allá de la desaparición física. En La condición humana, Arendt lleva a cabo una breve mención a este respecto, en la cual la muerte constituye el destino común capaz de igualar las desigualdades creadas por el mundo inequitativo de la política:

La igualdad que lleva consigo la esfera pública es forzosamente una igualdad de desiguales que necesitan ser «igualados» en ciertos aspectos y para fines específicos. Como tal, el factor igualador no surge de la «naturaleza» humana, sino de fuera [...]. La igualdad política, por lo tanto, es el extremo opuesto a nuestra igualdad ante la muerte (Arendt 2014: 236).

A pesar de poseer un cuerpo finito en términos biológicos, la vida política reescribe la naturaleza de dicho cuerpo a través del establecimiento una desigualdad material. Esta desigualdad estaría creada el por el artificio del mundo material, económico, y sus objetivos no serían otros más que naturalizar el establecimiento de dichas desigualdades.

\footnotetext{
${ }^{4}$ Serrano de Haro aclara la cuestión de la muerte y el recuerdo en Husserl: "si desaparece el cuerpo físico que soporta la aprehensión perceptiva del otro, ya sólo queda la posibilidad de un «recuerdo histórico» en que los sujetos «supervivientes» mencionan, evocan al otro una vez que el lugar de la percepción originaria del otro por sí ha quedado vacante" (Serrano de Haro en: Husserl 2006: 56).
} 


\subsection{Conclusiones del apartado}

La fenomenología husserliana no es ni Ciencia Natural ni Ciencia del Espíritu, posee características propias que la ubicarían por fuera de esta dicotomía. De hecho, intenta más bien dar explicaciones a fenómenos cotidianos, a cuestiones mundanas, a través del análisis del de la percepción, la conciencia, el pensamiento. Una de las principales preocupaciones de Husserl en este sentido radica en la búsqueda de los orígenes de los sentidos, de la génesis de la experiencia humana. Una vez hallados estos sentidos originales, quedaría abierta la posibilidad de pensar en una filosofía trascendental, capaz de gozar del mismo prestigio, la misma legitimación que el resto de las ciencias. Este intento de estudiar la génesis de la experiencia humana descontaminada de interpretaciones previas, influyó determinantemente en el devenir de la filosofía del siglo XX: al centrar la atención en cuestiones "mundanas" - sin por ello desatender de su relevancia epistémica-, la fenomenología allanó el camino hacia una revisión de los fundamentos universales constitutivos de la modernidad. Es en esta lógica que podemos afirmar que dicha corriente de pensamiento influyó en las ideas de Arendt, no solo por el afán de derribar los sólidos bloques de la modernidad -y más particularmente los de la ciencia moderna-, sino también por las reflexiones que la autora lleva a cabo en relación al cuerpo humano, la naturaleza, las actividades cotidianas y la relación del hombre con el mundo.

El ensayo de Husserl titulado La tierra no se mueve conlleva implícita una fuerte crítica al método de las Ciencias Naturales. Utilizando el movimiento como punto de partida, el autor mencionado analiza los efectos causados por la creencia en el movimiento de la Tierra, a partir de las explicaciones que otorgan diversos campos disciplinares como la cosmología o la física teórica. Este movimiento "natural", demostrado científicamente y verificado a partir de la aplicación del método cartesiano, permanece en una posición incuestionable pero no afecta visiblemente las acciones cotidianas de los hombres en la Tierra, dado que sus sentidos solo les permiten captar una porción finita del fenómeno. Al poner el discurso naturalista, la facticidad matemática por sobre lo imperfecto de la percepción humana, por sobre las nociones subjetivas de espacio y tiempo, no estaríamos haciendo más que distanciar el discurso científico de lo social. Y esta distancia es para Husserl una de las causas que justifican la fenomenología, como método capaz de solventar 
esas dificultades irreconciliables. Para este filósofo, la crisis de las ciencias -es decir, la diferenciación entre las Ciencias Naturales y las Ciencias del Espíritu- conduce, hacia principios del siglo XX, a una de las principales crisis de Europa. ${ }^{5}$ Fenómenos como el racismo y el totalitarismo encuentran medios legitimados en las Ciencias Tradicionales para distanciarse de lo humano, $\mathrm{y}$, de esa manera, colocar en el lugar de objeto experimental a la porción de la humanidad que se pretende desaparecer.

Esta crítica al positivismo, y más específicamente a la ciencia moderna, basada en un supuesto progreso lineal e infinito, es uno de los ejes que atraviesa varias obras de Arendt, particularmente Los orígenes del totalitarismo y La condición humana. Con respecto a la obra mencionada en segundo término, en el capítulo siguiente se desarrollará en profundidad el análisis de los componentes de la vita activa: la labor, el trabajo y la acción. En este contexto, la propuesta de Arendt no desatiende lo cotidiano, lo mundano; estos elementos no pierden valor en relación a la "seriedad" de la ciencia; la Tierra no es más importante que el mundo social y la filosofía no acompaña un discurso hegemónico universal. Todo está sujeto al ejercicio de una revisión histórico-política, incluso el discurso por el que las cuestiones mundanas, históricamente quedaron relegadas a un segundo orden de relevancia en el campo de los debates filosóficos.

\footnotetext{
${ }^{5}$ En un análisis más individualista y contemporáneo de la cuestión, Bachelard advierte sobre la presencia de una confusión - más vinculada a la filosofía que a la ciencia- por la cual los investigadores pretenden, de manera enfatizada, diferenciar el discurso científico del sentido común. Esta pretensión de "quitar lo humano" de aquello que fue pensado, justamente, por otros humanos, desencadena una confusión epistemológica que ubica a la ciencia por sobre toda práctica social. En sus propios términos: "en el espíritu mismo del investigador el pensamiento científico se separa del pensamiento común. El investigador termina siendo un hombre provisto de dos comportamientos, y está división confunde todas las discusiones filosóficas" (1978: 14). Siguiendo esta línea de análisis, la manera más eficaz de "hacer ciencia" estaría asociada a la aislación absoluta. Cabe suponer, con cierta ironía, que esta aislación podría incluso implicar, de ser necesario, la "eliminación" del componente humano-contaminante.
} 


\title{
Capítulo 2. Cuerpo y naturaleza en La condición humana
}

\begin{abstract}
No hay felicidad duradera al margen del prescrito ciclo de penoso agotamiento y placentera regeneración, y cualquier cosa que desequilibra este ciclo -la pobreza y la desgracia en las que el agotamiento va seguido por la desdicha en lugar de la regeneración, o las grandes riquezas y una vida $\sin$ esfuerzo alguno desde el aburrimiento ocupa el sitio del agotamiento y donde los molinos de la necesidad, del consumo y de la digestión, muelen despiadada e inútilmente hasta la muerte un cuerpo humano- destruye la elemental felicidad de estar vivo.
\end{abstract}

(Arendt, H. La condición humana)

\subsection{El cuerpo en la complejidad de la vita activa}

De acuerdo con lo explicado anteriormente, las actividades que se encuentran al alcance de todo ser humano, agrupadas en los conceptos de labor, trabajo y acción, resultan de particular interés para la autora mencionada, ya que estas actividades definen en gran parte la existencia humana. Desde la necesidad de comer, beber, vestirse y dormir, pasando por la producción de objetos y herramientas hasta la participación en la política y el uso del tiempo libre, constituyen actividades fundantes de la humanidad y, por lo tanto, desde la perspectiva de Arendt merecen su lugar en la historia y su respectivo análisis. En La condición humana, libro publicado originalmente en 1958 por la Universidad de Chicago, Arendt se lanza a la tarea de analizar la política imperante en la Modernidad, no sólo a partir del análisis de hechos cronológicamente rastreables en dicho período, sino también de la tradición del pensamiento político occidental, que se remonta a Platón. (Di Pego 2015: 214). Con una metodología de trabajo que desconfía del uso convencional de la historia y pone en su lugar una interpretación crítica del pasado -la cual recibió esperables acusaciones por parte de pensadores como Habermas o Macpherson, centradas en el abuso de subjetividad a la hora de indagar acontecimientos históricos-, Arendt se propone la audaz y provocadora tarea de analizar, bajo el concepto de vita activa, temas referidos tanto a la tradición occidental como a la modernidad.

A lo largo del libro, Arendt utiliza el concepto de cuerpo asociado a las tres actividades que conforman el principio de vita activa. Estas actividades configuran la complejidad de lo humano sólo en parte, puesto que la condición humana también se define a partir del ejercicio de la contemplación (práctica más asociada a la filosofía clásica que a 
la razón de la modernidad). Este ejercicio propiamente humano vinculado a la reflexión, comúnmente denominado por la tradición occidental como contemplación o vida contemplativa, implicaría según Arendt el pensamiento, la voluntad y el juicio. "Tradicionalmente, por lo tanto, la expresión vita activa toma su significado de la vita contemplativa; su muy limitada dignidad se le concede debido a que sirve las necesidades y exigencias de la contemplación en un cuerpo vivo" (Arendt 2014: 28). La propuesta de analizar no sólo lo que pensamos, sino también lo que hacemos y lo que nos define como humanos en el mundo que habitamos, es la marca de la filosofía arendtiana, que, lejos de proponerse tareas monumentales, nos brinda herramientas conceptuales para analizar nuestras acciones más mundanas.

Sin embargo, sería incorrecto elaborar un concepto único a partir de la lectura de $L a$ condición humana. La autora en cuestión no se preocupa por brindar una definición exacta; en un ejercicio teórico más complejo, se propone analizar de qué manera las interpretaciones históricas de labor, trabajo y acción implican al cuerpo de diversos modos. En esta línea, el concepto de cuerpo puede problematizarse vinculado a la labor, como un cuerpo biológico, preocupado por sí mismo y por los requerimientos básicos de la vida orgánica. El cuerpo asociado al trabajo, en cambio, hace referencia a un cuerpo segmentado, automático y alienado, atravesado por los intereses de un mercado que se mueve en la lógica de un mundo artificial y que sólo tiene sentido para el hombre como centro de ese universo limitado. ${ }^{1}$ Por último es posible rastrear la noción de un cuerpo en relación a la acción: éste implica no solo la acción -como sinónimo de movimiento intencionado que conlleva un objetivo-, sino que incluye el discurso como parte inherente a la expresividad humana.

Antes de profundizar el análisis respecto de la labor, el trabajo y la acción, es necesario revisar brevemente el concepto de naturaleza trabajado por Arendt en $\mathrm{La}$ condición humana y en su obra precedente, Los orígenes del totalitarismo. A diferencia de la idea comúnmente arraigada en el pensamiento occidental sobre la existencia de una naturaleza humana -lo que supone que habría algo innato en el ser humano que lo obligaría

\footnotetext{
${ }^{1}$ Cabe aclarar que el cuerpo asociado al trabajo también expresa cierta potencialidad creadora -en la forma de producción artesanal principalmente. A partir de la época moderna, con la forma de producción capitalista, dicha asociación pasa progresivamente a disolverse casi por completo (fundamentalmente a causa de la división y la automatización del trabajo).
} 
a vivir de determinada manera-, Arendt afirma que el total de las actividades y capacidades no están impresas desde el nacimiento, sino que se construyen condicionadas por la relación con el mundo que nos toca habitar. ${ }^{2}$

Determinadas organizaciones socio-políticas interesadas en la "dominación total" han demostrado, fundamentalmente a lo largo del siglo $\mathrm{XX}$, que es posible que las condiciones de existencia humana varíen de acuerdo al orden político y la ideología imperante en un momento histórico determinado: "El totalitarismo, a través de su funcionamiento sistemático y burocrático, ha llegado a ocultar al hombre su naturaleza con el pretexto de cambiarla" (Arendt 2008: 39).

La maldad asociada al totalitarismo consiste en reducir al hombre a la mera animalidad, sin que sea posible advertir en él características particulares de la existencia humana. Así, esta organización política ha puesto en evidencia que no es posible definir una naturaleza humana que se mantenga inalterada en cualquier circunstancia y que constituya por tanto la esencia del ser humano (Di Pego 2015: 215). En esta lógica, sería imposible afirmar que el ser humano cuenta con un sistema de defensa innato, capaz de eludir o enfrentar los instrumentos de un sistema político basado en el dominio total y por lo tanto no sería posible hallar una naturaleza humana "natural" y externa: esta debe su existencia al hombre, surge a partir de la capacidad del ser humano de fabricar naturaleza, es decir, de crear procesos naturales que sin los hombres no existirían (Arendt 2014: 251). De esta manera, la naturaleza puede tanto ser una condición a recrear en un laboratorio, algo digno de representar en un cuadro, o la justificación que sirvió al nazismo para llevar a cabo uno de los genocidios más masivos en la historia de la humanidad.

En los últimos apartados de Los orígenes del totalitarismo, Arendt resalta este vínculo entre lo humano y lo natural como algo perteneciente a la esfera de los asuntos humanos, y no como algo dado, esencial e inerte frente a la acción del hombre. Sería

\footnotetext{
${ }^{2}$ Cabe aclarar que cuando Arendt habla de naturaleza, no hace referencia al concepto de vita activa. Con el fin de esclarecer esta cuestión, resulta pertinente atender a las palabras de Di Pego: "El ser humano, según Arendt, no tiene una conformación particular preestablecida, sino que vive bajo ciertas condiciones de existencia, y por eso las distinciones dentro de la vida activa no deben entenderse como el establecimiento de una ontología determinada ni como clasificaciones rígidas y excluyentes, sino más bien como diversas dimensiones que se solapan y conviven, en el marco de las condiciones de vida a las que nos encontramos sujetos en nuestro mundo" (2015: 215). En resumen, podríamos afirmar que la noción de vita activa admite una "flexibilidad" en sus elementos, a diferencia de la naturaleza, cuya interpretación asociada al positivismo supone que el humano está predestinado a vivir como el resto de las especies, esto es, biológicamente determinado.
} 
precisamente la acción del hombre la que definiría la esencia de la naturaleza. En términos de Arendt:

La experiencia de los campos de concentración muestra que los seres humanos pueden ser trasformados en especímenes del animal humano y que la «naturaleza» del hombre es solamente «humana» en tanto que abre al hombre la posibilidad de convertirse en algo altamente innatural, es decir, en un hombre (Arendt 1998: 681)

Los nazis no solo pretendían exterminar aquella parte de la humanidad que no pertenecía a la raza aria; más bien pretendían ejercer un dominio total amparados en una noción de naturaleza propia, es decir, naturalizaban su dominio tanto hacia el interior de su partido, como en las poblaciones conquistadas (utilizando aquellos medios considerados más económicos y eficaces, como el terror, la propaganda y la violencia). La misma naturaleza era la que decidía no sólo quién tenía que ser eliminado, sino también quién tenía que ser preparado como ejecutor (Arendt 1998: 696). A la par del establecimiento de un sistema burocrático, propagandista e impersonal nunca antes visto en la historia de occidente, los líderes nazis utilizaron el concepto "evolutivo darwiniano" para justificar el progreso de la raza humana hacia un "tipo ideal" de hombre. Este modelo humano, "naturalmente superior" y fundamentado en los rasgos físicos de la raza aria, fue ideado fundamentalmente por Himmler $^{3}$ y puesto en práctica en los campos de concentración (puesto que la naturaleza inferior de los judíos, polacos, gitanos, homosexuales, comunistas, testigos de Jehová, enfermos mentales y discapacitados, permitía cualquier tipo

\footnotetext{
${ }^{3}$ Heinrich Himmler fue comandante en jefe de las SS y Ministro del interior del Interior del Tercer Reich. Con un alto rango en el partido nacionalsocialista alemán, fue uno de los principales ejecutores del programa de eugenesia ideado por Hitler. El alto funcionario trabajó en diversos campos de concentración a la par de numerosos médicos y científicos, avalando y garantizando una provisión permanente de "especímenes humanos" para llevar a cabo diversos experimentos. La selección de estos sujetos (hechos prisioneros en sus pueblos de origen), se basaba en un examen antropométrico, a través del cual se determinaba si los mismos alcanzaban, o no, los estándares germánicos ideales. En su libro titulado Eichmann en Jerusalén, Arendt describe el tema médico asociado a la sistematización del exterminio como uno de los "grandes momentos del juicio", puesto que se develó lo que todos sospechaban: la influencia ideológica, científica y material de los médicos afiliados al partido nazi. En sus propios términos: "Las primeras cámaras de gas fueron construidas en 1939, para cumplimentar el decreto de Hitler, dictado en $1^{\circ}$ de septiembre del mismo año, que decía que «debemos conceder a los enfermos incurables el derecho a una muerte sin dolor» (probablemente este es el origen «médico» de la muerte por gas, que inspiró al doctor Servatius la sorprendente convicción de que la muerte por gas debía considerarse como un «asunto médico»). La idea contenida en este decreto era, sin embargo, mucho más antigua. Ya en 1935, Hitler había dicho al director general de medicina del Reich, Gerhard Wagner, que «si estallaba la guerra, volvería a poner sobre el tapete la cuestión de la eutanasia, y la impondría, ya que en tiempo de guerra es más fácil hacerlo que en tiempo de paz». El decreto fue inmediatamente puesto en ejecución, en cuanto hacía referencia a los enfermos mentales. Entre el mes de diciembre de 1939 y el de agosto de 1941, alrededor de cincuenta mil alemanes fueron muertos mediante gas de monóxido de carbono, en instituciones en las que las cámaras de la muerte tenían las mismas engañosas apariencias que las de Auschwitz, es decir, parecían duchas y cuartos de baño." (Arendt, H. 1999: 107).
} 
de práctica experimental por parte de los funcionarios nazis, al igual que un científico puede experimentar con ratas en su laboratorio). Esta naturalización de la diferencia y efecto de la mano del hombre queda expuesta por Arendt del siguiente modo:

Cuando los nazis hablaban sobre la ley de la Naturaleza o cuando los bolcheviques hablan sobre la ley de la Historia, ni la Naturaleza ni la Historia son ya la fuente estabilizadora de la autoridad para las acciones de los hombres mortales; son movimientos en sí mismas. Subyacente a la creencia de los nazis en las leyes raciales como expresión de la ley de la Naturaleza en el hombre, se halla la idea darwiniana del hombre como producto de una evolución natural que no se detiene necesariamente en la especie actual de seres humanos (Arendt 1998: 691).

\subsection{Las actividades vinculadas a la labor y los procesos vitales del cuerpo}

La labor, entendida en la lógica de Arendt como la más natural y menos mundana de las actividades del hombre, incluye las actividades necesarias para asegurar el proceso vital del cuerpo. Entre estas actividades se encuentran la satisfacción de las necesidades biológicas, históricamente consideradas, en occidente, como no perdurables y en contra del goce asociado a la idea de libertad. A lo largo del desarrollo de La condición humana, estas ocupaciones están asociadas a la figura del animal laborans, metáfora explicativa del hombre encerrado en las demandas de su propio cuerpo e impedido de experimentar la vida humana en todo su potencial. ${ }^{4}$ En la lógica de Arendt, el laborar es una actividad en la que el hombre no está junto con el mundo ni con los demás, sino sólo con su cuerpo, frente a la desnuda necesidad de mantenerse vivo (Arendt 2014: 235). Si bien el hombre vive en presencia de y junto a otros, esta cercanía no implica intercambio, más allá de laborar conjuntamente como eslabones en una cadena de ensamblaje.

Los procesos corporales considerados vitales, como respirar, comer, hidratarse, defecar, dormir, reproducirse, entre otros, podrían considerarse como actividades pertenecientes a la labor, si bien la forma en que se llevan a cabo varía considerablemente de una cultura a otra. Estas actividades están comúnmente asociadas al esfuerzo, al sufrimiento y al dolor, $\mathrm{y}$ al recuerdo permanente de las necesidades que atraviesan la existencia humana. La respuesta de Arendt frente a esta interpretación histórica se orienta

\footnotetext{
${ }^{4}$ La figura del animal laborans también es utilizada por Arendt para el análisis del derrotero del siglo XX, en relación con el papel preponderante que la labor pasa a cumplir respecto de los demás componentes de la vita activa. Este acontecimiento daría lugar a la existencia de una sociedad de masas seducidas por el consumo y la lógica artificial del mercado.
} 
hacia la reivindicación de estos quehaceres como elementos fundantes y dignos de análisis (al igual que el resto de las actividades de la vita activa). Tan mundanos que no solemos percatarnos de su existencia, Arendt advierte sobre la permanente búsqueda del hombre por desligarse de las actividades asociadas con la labor. Desde el punto de vista biológico esto sería imposible; sin embargo, el hombre se las ha ingeniado para disminuir el tiempo destinado a la labor, y así disponer de más tiempo libre para otras actividades consideradas menos indignas y degradantes.

Arendt retoma la preocupación de Locke por asociar el concepto de propiedad privada a la idea de la "propia persona", o sea, el "propio cuerpo". Locke remonta la propiedad hasta un origen natural que encierra la parte privada de cada persona separándola del mundo “de lo común”. En esta lógica del pensamiento, las necesidades, demandas y placeres quedarían relegadas a la esfera del mundo privado (alejado de la intromisión de otras personas). El problema que señala Arendt respecto de esta preocupación por el sí mismo, es que un sujeto con la mirada exclusivamente dirigida hacia adentro atravesaría una existencia más asociada a la animalidad que a la condición humana. Un sujeto arrojado a la satisfacción de sus necesidades, de sus supuestos instintos, se encontraría imposibilitado de transitar la complejidad de la vida humana, y por lo tanto sería un humano "sin humanidad", constituido sólo a partir de la apariencia física y la satisfacción de sus necesidades vitales:

La única actividad que corresponde estrictamente a la experiencia de no mundanidad o, mejor dicho, a la pérdida del mundo tal como ocurre bajo el dolor, es la labor, donde el cuerpo humano, a pesar de su actividad, vuelve sobre sí mismo, se concentra sólo en estar vivo, y queda apresado en su metabolismo (Arendt 2014: 124).

El dolor es un claro exponente de esta demanda del cuerpo respecto de sus necesidades vitales (aunque circunstancialmente puede resultar de una causa externa, la sensación del dolor generalmente se suele ubicar en el interior del cuerpo). El dolor es el principal requerimiento del cuerpo, la ausencia del mismo sólo es un momento pasajero hasta la nueva aparición de esta sensación capaz de captar toda la atención. La desaparición del dolor es una ilusión a través de la cual alguien puede considerar que ha quedado librado de él, pero en verdad es sólo una transición hasta su retorno y la consecuente demanda de atención. Cuando nos encontramos atravesados por un sufrimiento, difícilmente podemos relacionarnos con el mundo, el cuerpo se transforma en un padecimiento que llama a poner 
todas las energías sobre él, e intentar subsanar la dolencia. Señala Arendt: "La ausencia de dolor no es más que la condición corporal para conocer el mundo; sólo si el cuerpo no está irritado y, con la irritación, vuelto sobre sí mismo, pueden funcionar normalmente nuestros sentidos, recibir lo que se les da" (Arendt 2014: 123).

Habitar un cuerpo y experimentar dolor son dimensiones inherentes a la condición humana y, retomando los aportes de Locke, corresponden a la esfera privada ya que no se puede compartir un cuerpo ni trasladar un padecimiento de un cuerpo a otro. El dolor, entonces, aparece vinculado intrínsecamente a la labor en tanto el cuerpo humano vuelve sobre sí mismo y sus necesidades vitales, lo que impide el conocimiento del mundo. Así, la inclusión de actividades asociadas con la labor en la esfera de lo privado puede resultar en una estrategia política para legitimar una modalidad de dominio, cuyo funcionamiento puede rastrearse en los orígenes del pensamiento político occidental. Para los griegos, las tareas asociadas a la labor eran consideradas degradantes y condicionantes de una vida plena (asociada a los placeres y al goce de privilegios); este es el principal motivo por el que los esclavos debían cargar con las labores de sus poseedores. Sólo la liberación de las demandas de la vida biológica aseguraría el goce de una vida plena, cuyas principales preocupaciones se centrarían alrededor de alrededor de la filosofía y la política (entendidas en el pensamiento de Arendt como expresiones fundamentales de la acción). El carácter mundano de la labor no sería tal, si lo interpretamos asociado a la necesidad de los griegos, por legitimar una modalidad de gobierno amparada en la asignación de tareas para el beneficio de sus gobernantes. En palabras de Arendt:

La carga de la vida biológica, que lastra y consume el período de la vida humana entre el nacimiento y la muerte, sólo puede eliminarse con el empleo de sirvientes, y la función principal de los antiguos esclavos era más llevar la carga del consumo del hogar que producir para la sociedad en general (Arendt 2014: 128).

Tanto la palabra como la acción, elementos constitutivos de lo humano en su particularidad, históricamente se hallaron separados por intereses políticos rastreables desde la antigua Grecia; estos intereses responden a la necesidad de los gobernantes de establecer su posición de dominio y desligarse del degradante dolor y sufrimiento que implica la carga de la labor, carga que al mismo tiempo define la existencia humana, su relación con el mundo y la separación de otras especies. 
La alternativa a sufrir la carga de la labor de otros implica el uso de la violencia y el riesgo de perder la vida. En la antigua Grecia, estos riesgos llevaban consigo la idea de liberación, que daría como resultado un nacimiento humano más allá de la degradante condición de esclavo. El paso de pertenecer a ser no implicaba un acontecimiento pacífico y librado de riesgos; por el contrario, la búsqueda de la libertad suponía arriesgar la propiedad más preciada que un humano es capaz de poseer: su propia vida. Según Arendt:

El precio pagado por liberar la carga de la vida de los hombros de los ciudadanos era enorme, y en modo alguno consistía solo en la violenta injusticia de obligar a una parte de la humanidad a adentrarse en las tinieblas del dolor y de la necesidad (Arendt 2014: 128).

En esta lógica, es imposible concebir el cuerpo como algo único y estable, y mucho menos homogéneo si se tiene en cuenta la influencia de la política. A pesar de pertenecer a la misma especie, de poseer los mismos huesos, órganos y articulaciones, siguiendo las reflexiones de Arendt no sería posible afirmar que el cuerpo del esclavo es igual al cuerpo del filósofo; ni mucho menos similar al cuerpo de un gladiador o un artesano. Puesto que el cuerpo se define a partir de sus acciones y del rol que juega en la vida política (en el caso de los griegos, de la vida y la organización política en la polis), no puede hallarse un concepto de cuerpo homogéneo y aplicable a la infinidad de acciones que comprende la condición humana.

El cuerpo no sólo es digno de ser problematizado en los asuntos humanos, es inherente a la condición humana, y sólo en la medida en que se lo problematice asociado a la labor como actividad fundante de lo humano -incluso con la fatiga y la molestia que implica habitar el mundo- podremos entender los condicionantes que atraviesan su existencia. La ausencia del dolor y el sufrimiento atentarían contra la experiencia de habitar el mundo, es decir, contra la experiencia de la humanidad misma, puesto que el hombre requiere de su relación con el mundo y con otros hombres para asegurar su propia vida:

En su nivel más elemental, la fatiga y molestia de obtener el placer de incorporar las necesidades de la vida están tan estrechamente unidos en el ciclo biológico de la vida, cuyo repetido ritmo condiciona la vida humana en su único y lineal movimiento, que la perfecta eliminación del dolor y del esfuerzo laboral no sólo quitaría a la vida biológica sus más naturales placeres, sino que le arrebataría su misma viveza y vitalidad. La condición humana es tal que el dolor y el esfuerzo no son meros síntomas que se pueden suprimir sin cambiar la propia vida, junto con la necesidad a la que se encuentra ligada, se deja sentir. Para los mortales, la vida fácil de los dioses sería una vida sin vida (Arendt 2014: 129).

En esta línea de interpretación, es posible afirmar que una vida sin esfuerzo, sin sacrificio, es una vida entregada a la desgracia del agotamiento y el aburrimiento, donde la necesidad 
y el consumo acechan y digieren un impotente cuerpo hasta la muerte. En el otro extremo se encuentra la felicidad, que, asociada a la labor, se hallaría en la noción de un cuerpo sano, capaz de llevar a cabo la mundana, agobiante y fascinante tarea de habitar el mundo: "La vitalidad y viveza sólo pueden conservarse en la medida en que el hombre esté dispuesto a tomar sobre sí la carga, fatiga y molestia de la vida" (Arendt 2014: 129).

\subsection{El cuerpo alienado a la incesante demanda del trabajo}

Debido a la preocupación de Arendt por la relación del hombre con la propiedad y el crecimiento de la riqueza, el trabajo y el consumo se hallan entre los temas más minuciosamente analizados a lo largo de La condición humana. Estos son temas recurrentes y dignos de problematizar vinculados a la noción de cuerpo; entendido en relación al trabajo como un objeto alienado a la lógica de un mundo automatizado. Es en estos términos que Arendt pone el acento en los esfuerzos del hombre por recrear la naturaleza idea también impuesta por el hombre para justificar su relación violenta y usufructuaria con el mundo.

Atendiendo específicamente a las reflexiones desarrolladas por Arendt en este sentido, resulta pertinente considerar lo expresado en el capítulo destinado al trabajo en $\mathrm{La}$ condición humana, que comienza del siguiente modo:

El trabajo de nuestras manos, a diferencia del trabajo de nuestros cuerpos -el homo faber que fabrica y literalmente trabaja sobre, diferenciado del animal laborans que labora y mezcla con-, fábrica la interminable variedad de cosas cuya suma total constituye el artificio humano (Arendt 2014: 157).

Al analizar en detalle el párrafo citado anteriormente es posible notar que la filósofa diferencia el trabajo de las manos y la labor del cuerpo. ${ }^{5}$ Esta separación -incómoda para la noción de cuerpo material, homogéneo y uniforme que históricamente se impuso en occidente-, hace referencia de manera simbólica a la falta de pensamiento que implica el trabajo manual sistematizado, producto de la demanda de un mundo artificial. Mientras que las manos encarnan lo que Marx denominaría una "fuerza de trabajo"-entendida como un bien que ocupa un lugar en un mercado de valores-, el homo faber encarnaría un prototipo

\footnotetext{
5 A pesar de que la versión citada utilice el término "trabajo", basándome en las versiones originales (publicadas en inglés), prefiero utilizar aquí el concepto de "labor".
} 
ideal de sujeto productivo, económico, eficiente, cuyo cuerpo se encontraría alienado a la demanda de un mundo guiado por la división del trabajo y su automatización.

Mientras que el animal laborans centra su atención sobre sí mismo y sobre las demandas del propio cuerpo para asegurar su subsistencia, ${ }^{6}$ el homo faber no tiene preocupación alguna más que cumplir con sus tareas. Su existencia vacía de pensamiento reflexivo, destinada a ocupar un lugar en la cadena de producción, encuentra sentido en la reiterada operatividad de su conducta. Incluso el homo faber de la modernidad ha subestimado las posibilidades de pensar y actuar, a cambio de obedecer a una lógica de consumo impersonal y alienante, vinculando el trabajo a la labor y reduciendo el trabajo creativo, artesanal y productivo a una a mera repetición y respuesta automática. Siguiendo el ejemplo citado en el párrafo anterior, y atendiendo fundamentalmente a la división del trabajo desarrollada en la época moderna, podríamos afirmar que las manos del homo faber responden al pensamiento de otros. En un sentido metafórico, no pertenecerían al humano aunque físicamente así sea-, son parte de un mundo "capital” y, al igual que los productos que manufactura, únicamente poseen un precio y un sentido en un mercado de valores.

El hombre moderno ha llegado a elaborar un discurso alrededor del cuerpo por el que su salud, necesaria para las actividades asociadas al trabajo, se ha convertido en objeto de interés de la medicina y de otras disciplinas encargadas de la manutención de sus capacidades productivas. La victoria del animal laborans en la modernidad tardía depende de un determinado funcionamiento del cuerpo humano, asegurado por numerosas disciplinas que facilitan su presencia como un eslabón más en la lógica del consumo -este tema se ampliará más adelante.

A partir de la modernidad, el trabajo se centró en facilitar la labor, mezclándose a tal punto de convertirse él mismo en labor; fundamentalmente, a través de la fabricación de instrumentos destinados a alivianar la fatiga que supone habitar el mundo. Con la revolución industrial se reemplazaron los productos de la artesanía por los productos de la

\footnotetext{
${ }^{6}$ La figura del animal laborans encarna al hombre preocupado por el hombre, o a lo sumo preocupado por la demanda de otros que lo dominan bajo la lógica de la esclavitud o el dominio explícito. El animal laborans mantiene una relación interna y al mismo tiempo excluyente con su cuerpo; en palabras de Arendt: "El animal laborans no huye del mundo, sino que es expulsado de él en cuanto que está encerrado en lo privado de su propio cuerpo, atrapado en el cumplimiento de necesidades que nadie puede compartir y que nadie puede comunicar plenamente" (Arendt 2014: 128).
} 
labor, lo que resultó en que las cosas del mundo moderno tengan como destino su consumo (en vez de ser productos destinados a su uso). En términos de Arendt:

Vivimos en una sociedad de laborantes debido a que sólo el laborar, con su inherente fertilidad, es posible que origine abundancia; y hemos cambiado el trabajo por el laborar, troceándolo en minúsculas partículas hasta que se ha prestado a la división, donde el común denominador de la más sencilla realización se alcanza con el fin de eliminar de la senda de la fuerza laboral humana -que es parte de la naturaleza e incluso quizá la más poderosa de todas las fuerzas naturales- el obstáculo de la no natural y puramente mundana estabilidad del artificio humano (Arendt 2014: 135).

Esta cita da cuenta de la paradojal relación que existe entre la finitud del hombre y la trascendencia del mundo material; la fuerza laboral humana se esmera en la creación de un mundo artificial cuya finitud excede su propia condición. El cuerpo es atravesado por el discurso de la utilidad y la productividad hasta el punto en que él mismo es un producto más, destinado a ser expuesto y valorado en el mundo de valores asignados por la lógica artificial de un mercado de cambio. La naturaleza "productiva" del hombre no es más que una convicción por la que se intenta otorgarle sentido a una práctica alienante, cuyos resultados son expuestos en un mundo ajeno, paradójicamente construido y defendido por los hombres.

Arendt señala la confusión, presente en la modernidad, sobre el trabajo entendido como sinónimo de labor. Al analizar en detalle ambos términos en relación al concepto de vita activa, podemos percatarnos de que en realidad, labor y trabajo pertenecen a esferas distintas de la actividad humana. En el trabajo, los hombres manifiestan diferentes habilidades, pero en la labor conjunta cada hombre es reemplazable por cualquier otro, porque en la labor solo está en juego la unidad de la especie con respecto a la cual cada individuo es intercambiable (Di Pego 2015: 232).

Cuando observamos a un grupo de alumnos reunidos en un salón de clase bajo los parámetros de la escuela moderna tradicional, a un batallón de soldados marchando juntos, o a los operarios de una fábrica ejerciendo las mismas tareas en una cadena de producción, podríamos afirmar, según la lógica arendtiana, que estamos frente a un conjunto de cuerpos laborando al mismo tiempo. A pesar de que varias personas puedan compartir espacios, horarios o funciones, dicha comunión no necesariamente implica el reconocimiento del otro, de su identidad y su libertad. Bajo la noción "laborar juntos" se establece un vínculo, más que con la individualidad de los otros, con la sincronía del cuerpo y de sus ritmos 
biológicos. Este laborar en conjunto disminuiría la fatiga y la molestia que conllevan las actividades asociadas a la labor. Cito en extenso:

En la naturaleza del laborar radica que los hombres se junten en forma de grupo de labor, donde cualquier número de individuos laboran juntos como si fueran uno. [...] Pero esta naturaleza colectiva de la labor lejos de establecer una reconocible, identificable realidad para cada miembro del grupo de labor, requiere por el contrario la verdadera pérdida de todo conocimiento de individualidad e identidad. [...] La sociabilidad de esas actividades que surgen del cuerpo humano con la naturaleza no se basa en la igualdad, sino en la identidad, [...] relacionada con la experiencia somática de laborar juntos, donde el ritmo biológico de la labor une al grupo de laborantes hasta el punto de que cada uno puede sentir que ya no es un individuo, sino realmente uno con todos los otros (Arendt 2014: 236).

De acuerdo a lo expuesto hasta el momento, la "división de la labor" abarca aquellas actividades -común y confusamente asociadas al trabajo- que, por su mecanicidad y automatismo, no requieren más que la presencia física de un individuo. A este tipo de actividades, en las cuales no se requiere especialización alguna más que la requerida para ocupar un lugar de acuerdo a determinada función, y donde un sujeto es reemplazable por otro, corresponde un análisis vinculado a las actividades enmarcadas bajo el concepto de labor. Esta degradación del trabajo, de la mano de obra especializada a un cuerpo orgánico intercambiable, es uno de los motivos por el que Arendt sostiene que la labor ha desplazado al trabajo en la modernidad. Al respecto, afirma Di Pego:

En nuestras sociedades se produce el eclipse del homo faber frente a la centralidad creciente del animal laborans. La sociedad de productores ha sido reemplazada por una sociedad de consumidores cuyas necesidades se recrean incesantemente de acuerdo con las exigencias del mantenimiento del ciclo biológico (Di Pego 2015: 234).

Un segundo motivo que daría explicación a este ascenso de la labor -y, en un sentido más amplio, al ascenso de las actividades asociadas a la vida activa por sobre la vida del espíritu- se puede rastrear en el lugar que ocupa el consumo en las sociedades modernas. ${ }^{7}$ A partir de la modernidad (y de los desarrollos tecnológicos asociados al aumento en los volúmenes de fabricación de manufacturas), la repetición y el automatismo del trabajo se orientan, más que a la especialización de la mano de obra y la producción de objetos, hacia la reproducción de la vida. Arendt sostiene que vivimos en una sociedad de

\footnotetext{
${ }^{7}$ En este punto cabe aclarar que hay dos movimientos en la época moderna: por un lado, en oposición a la tradición, la vida activa ocupa un lugar dominante frente a la vida contemplativa; pero por otro lado se produce una inversión al interior de la vida activa y la labor, que era la actividad más desvalorizada tradicionalmente, pasa a ocupar el lugar más elevado.
} 
laborantes que persigue la satisfacción de las necesidades, la abundancia y el consumo (Di Pego 2015: 235).

De la mano de este acenso de la labor en la vita activa y de la supremacía del animal laborans por sobre el homo faber, la reproducción de la vida biológica ocupa un lugar central en la política. En la esfera de los asuntos públicos, la política, devenida más precisamente en biopolítica, ${ }^{8}$ tiene una preocupación central orientada a la gestión de vida y la determinación de los espacios de libertad. Los "estados de bienestar" de la posguerra se erigen como prototipos de esta biopolítica que modela la vida a través de las políticas públicas de natalidad, de familia, de salud, de trabajo (Di Pego 2015: 235).

Otra diferencia fundamental entre labor y trabajo radica en que la labor requiere de la continua repetición -hasta que la muerte ponga fin al organismo-, mientras que el trabajo finaliza inmediatamente cuando se termina el producto que se pretende vender o intercambiar. El laborar acude al continuo llamado de las necesidades vitales, es decir, debe satisfacer las demandas de la vida biológica, con la consecuente fatiga y sufrimiento que implica llevar a cabo este tipo de tareas -consideradas por los griegos como actividades degradantes por su carácter efímero e intranscendente. En esta línea, Di Pego afirma:

El carácter cíclico del laborar se pone de manifiesto en la relación continua, repetitiva e inacabada entre laborar y consumir. La labor es sumamente destructiva porque su actividad solo se lleva a cabo con el fin de aniquilar, es decir, consumir la materia obtenida. Sin embargo, en relación a la naturaleza, la labor es menos destructiva que el trabajo, puesto que si bien ambos extraen materiales de la naturaleza, esta los devuelve luego del metabolismo del cuerpo vivo, mientras que el trabajo erige un mundo de cosas artificiales duraderas (Di Pego 2015: 232).

Es común hallar en los escritos de Arendt una crítica respecto de la cultura del consumo, en especial cuando hace referencia al trabajo sencillamente como una más de las actividades que componen la vita activa. El trabajo se ve reducido en la modernidad a un proceso

\footnotetext{
${ }^{8}$ La biopolítica es un concepto que hace alusión al vínculo entre la política y la vida, donde el Estado, lejos de refugiarse en el discurso jurídico e impersonal afiliado al contrato social, actúa sobre el cuerpo y las voluntades de las personas legitimando determinadas prácticas y saberes, de entre los cuales sobresale la medicina (dado el interés explícito en el estudio y control del cuerpo humano). Al respecto señala Foucault: "El control de la sociedad sobre los individuos no se operó simplemente a través de la conciencia o de la ideología, sino que se ejerció en el cuerpo, y con el cuerpo. Para la sociedad capitalista lo más importante era lo biopolítico, lo somático, lo corporal. El cuerpo es una realidad biopolítica; la medicina es una estrategia biopolítica" (Foucault 1999: 366). La biopolítica es un tema que ameritaría un desarrollo más extenso para entender sus alcances e implicancias teóricas, e incluso se podrían rastrear ciertas similitudes con el concepto de labor propuesto por Arendt -análisis también sugerido por Agamben en Homo Sacer. El poder soberano y la nuda vida. A los objetivos de este trabajo, sin embargo, me limitaré simplemente a su mención, sin descartar una profundización sobre dicha temática en el futuro.
} 
exacerbado de consumo cuya finalización está lejos de avizorarse. Una crítica sobre esta práctica -que se instauró y difundió en occidente a partir de la Revolución Industrial, y que ganó terreno gracias a los avances en la tecnología aplicada a la manufacturación de productos- radica en la distorsión vigente que asocia la idea consumo a la noción de felicidad. La combinación de ambos elementos no haría otra cosa más que reforzar la irreflexión y creación de una realidad ilusoria, donde la supuesta "realización personal" se vincula con el consumo de productos. En esta lógica materialista, la relación con el mundo no se establece a partir de la mediación de la capacidad del hombre de interactuar con sus potencialidades, sino del consumo de productos que facilitan la vida cotidiana. El problema de esta mediación materializada es que el hombre, pretendiendo transitar una vida con menos esfuerzo y tiempo destinado al sufrimiento que implica la labor, ha reducido su existencia a los objetos que consume:

Cuanto más fácil se haga la vida en una sociedad de consumidores o laborantes, más difícil será seguir conociendo las urgencias de la necesidad, e incluso cuando existe dolor y esfuerzo, las manifestaciones exteriores de la necesidad apenas son observables. El peligro radica en que tal sociedad, deslumbrada por la abundancia de su creciente fertilidad y atrapada en el suave funcionamiento de un proceso interminable, no sea capaz de reconocer su propia futilidad (Arendt 2014: 142).

A partir de estas reflexiones, se podría afirmar que cuando el hombre reduce su vida al consumo desenfrenado no hace otra cosa que consumir su humanidad, encerrándose en un fragmento artificial respecto de las infinitas potencialidades que ofrece la condición humana. El hombre moderno, trabajador irreflexivo y enajenado por intereses externos, transita su vida por un mundo fútil, insignificante, y sin embargo lo hace convencido de que ese mundo es trascendente y responde a una deslumbrante y ficticia materialidad; al menos, es allí donde encuentra el sentido de su existencia y reduce toda posibilidad de acción.

Reducir la existencia humana al crecimiento de la riqueza para poder consumir más y más, para formar parte de una economía del derroche, desvía las prioridades asociadas a la acción y en cambio se centra en el mundo cíclico, ficticio y efímero del consumo. El análisis de Arendt respecto de los peligros que encierra el transitar por una vida exclusivamente guiada por los pilares del consumo, nos lleva a la siguiente afirmación: el cuerpo que consume básicamente se consume a sí mismo. Es reducido, se desliga de sus potencialidades y se arroja a los principios utilitaristas basados en el intercambio de "fuerza productiva" por "fuerza de consumo". 


\subsection{Las implicancias de la acción}

El concepto de acción posee un gran valor en la obra de la autora, ya que se encuentra presente en gran parte de sus escritos. Desde mi punto de vista, este concepto es una de las marcas teóricas que la colocan entre las pensadoras más influyentes del siglo XX, no solo por su vínculo cercano con la idea de libertad, sino por su permanente asociación al campo de la política moderna.

En Sobre la violencia, Arendt plantea que "Cada acción, para bien y para mal y cada accidente necesariamente destruyen toda la trama en cuyo marco se mueve la predicción y donde encuentra su prueba" (2006: 15). Más allá de las consecuencias, de los contextos y de las justificaciones, la palabra y el acto -inconcebibles en el mundo artificial del trabajo y desligadas de la atención que demanda la vida biológica- confluyen en la acción propiamente dicha, la única de las actividades que posee un carácter impredecible, irreversible y transcurre en la pluralidad. La acción implica la palabra y el acto con todo el potencial que conllevan a la existencia humana, lo que la vuelve la actividad más vinculada al concepto de libertad (con los recaudos teóricos que conlleva el uso de este término en occidente, debido a su paradojal sujeción e interpretación de acuerdo a las variables de los diversos sistemas políticos).

El modo en que los hombres se distinguen entre sí -es decir, el modo en que se presentan con sus características particulares en un mundo habitado por otros hombres- es a través de la acción, la cual se encuentra, por lo general, acompañada por el discurso.

Con el uso de la palabra y la acción se hace posible reconocer marcas particulares que no son iguales entre todos los seres humanos (como si ocurre en el caso de la labor). La acción y el discurso hacen posible el reconocimiento del otro, y al mismo tiempo que nos reconozcan como sujetos particulares, con deseos, intereses, gustos, prácticas, etcétera características que sin la mediación de la palabra no tendrían sujeto y sin la acción no se harían visibles. Aclara Di Pego:

Mientras que es posible vivir sin laborar, forzando a otros a que laboren por uno, y también vivir sin trabajar, es decir, sin producir ningún tipo de objeto útil, no es posible seguir reconociendo una existencia como humana si no es capaz de actuar. En cuanto el hombre deja de ser capaz de actuar, también ha dejado de existir para el mundo común (Di Pego 2015: 236). 
Una acción sin un "quién" carece de significado; los monumentos a los soldados muertos en combate cuyos cadáveres ha sido imposible reconocer, dan cuenta de esta necesidad por acuñar un nombre a la acción por la que se los recuerda.

En el caso de la guerra, la acción conlleva una marcada intención que inclina la balanza en favor del acto por sobre la importancia del discurso; en este caso la palabra no tiene un peso relevante en relación a la acción. La acción se vuelve un medio violento para conseguir un fin, y el discurso se vuelve "mera charla" que no revela nada. En estas situaciones la acción se asemeja al carácter instrumental del trabajo y la obra conserva su pertinencia conozcamos o no a quien la hizo (Di Pego 2015: 236). El conflicto bélico pone en juego los intereses por la consecución de un fin sin importar los medios ni las consecuencias, y la destrucción que deja tras su paso evidencia la catastrófica consecuencia de este tipo de acciones, aunque no conozcamos particularmente a los protagonistas de dichos actos. ${ }^{9}$ En términos de Arendt:

Sin la revelación del agente en el acto, la acción pierde su específico carácter [...], no es menos medio para un fin que lo es la fabricación para producir un objeto. Esto ocurre siempre que se pierde la contigüidad humana [...]. Por ejemplo, durante la guerra, cuando los hombres entran en acción y emplean medios de violencia para lograr ciertos objetivos en contra del enemigo (Arendt 2014: 204).

En estos casos en los que el discurso pasa a un segundo plano, o mejor dicho, su peso como recurso pacífico y mediador es desestimado a cambio de la violencia muda, ${ }^{10}$ la palabra se convierte en un medio más para alcanzar un fin determinado. Ya sirva para engañar al enemigo o para deslumbrar a todo el mundo con la propaganda, las palabras no revelan nada (Arendt 2014: 204). Dicho de otra manera, el uso de las palabras conlleva una

\footnotetext{
${ }^{9}$ Para este tipo de eventos catastróficos, Arendt reserva un minucioso análisis en su libro Eichmann en Jerusalén, donde desarrolla la peligrosidad asociada a un ser humano irreflexivo y ciegamente obediente. La irreflexión, el automatismo y la burocracia, aplicados a niveles masivos, darían lugar al funcionamiento de organizaciones políticas como el nazismo. Allí se destaca una banalidad del mal evidenciada en los actos cotidianos de los supuestos "monstruos", que no serían más que funcionaros públicos dedicados a ejecutar órdenes de manera sistemática, desatendiendo los trasfondos filosóficos que sustentan dichos mandatos.

${ }^{10}$ En relación al valor del discurso, resultan pertinentes los aportes de Zizek, quien, a partir de una relectura de Lacan -particularmente respecto de la función pacificadora del lenguaje-, afirma que en la palabra se encuentra clave para la convivencia y la aceptación de las diferencias. En términos del autor: "En el lenguaje, en vez de ejercer violencia directa sobre el otro queremos debatir, intercambiar palabras, y tal intercambio, incluso cuando es agresivo, presupone un reconocimiento mínimo de la otra parte. La entrada en el lenguaje y la renuncia a la violencia son a menudo entendidas como dos aspectos de un mismo gesto: hablar es el fundamento y la estructura de la socialización y se caracteriza por la renuncia a la violencia” (Zizek 2008: 78).
} 
intención tan marcada, que en esta utilización intencionada del lenguaje sería muy difícil encontrar espacios de verdadero diálogo.

Reafirmando lo dicho más arriba, un cuerpo despedazado por la artillería enemiga se transformaría en un sencillo pedazo de carne; y sólo a través de un funeral, un relato o un monolito, ese cuerpo es devuelto a la humanidad que le fue violentamente arrebatada. ${ }^{11} \mathrm{El}$ caso de los militares caídos en combate nos ayuda a comprender este vínculo entre el “quién” y la acción, ya que la muerte no destierra su humanidad, más bien la trasciende hacia la inmortalidad asociada al heroísmo y el sacrificio. Según Arendt,

La repugnancia a resignarse al hecho brutal de que el agente de la guerra no era realmente nadie, inspiró la erección de los monumentos al desconocido, a todos los que la guerra no había dado a conocer, robándoles no su realización, sino su dignidad humana (2014: 205).

Sin los cementerios o los monumentos a los soldados caídos, ${ }^{12}$ las nuevas generaciones de militares probablemente se preguntarían si su sacrificio conllevaría algún valor, es decir, si la muerte pondría fin a su vida y también sus acciones, o éstas trascenderían bajo la figura del héroe caído luchando por una causa justa.

\subsection{Los obstáculos de la acción}

La condición humana no es una obra que exalte los atributos de la acción como una cualidad trascendente y superadora frente a los obstáculos que atraviesan la vida de los

\footnotetext{
${ }^{11}$ En investigaciones anteriores referentes al militarismo y a los estigmas asociados al Síndrome por Estrés Postraumático, es destacable el modo verbal en que varios excombatientes de la guerra de Malvinas entrevistados se referían a sus compañeros caídos (Patierno, 2011). Tanto en la referencia a sus nombres de pila, a su participación en determinadas misiones o al recuerdo de anécdotas vividas en común, en todos los casos los verbos eran conjugados en tiempo presente. Ya sea debido a la vigencia del trauma en sus vidas de posguerra, o al uso del lenguaje que conocían, eran sorprendentes los detalles que se evidenciaban en sus relatos cuando describían diversas situaciones vividas 27 años antes del momento de las entrevistas. Como si el entrevistado, al momento de traer el recuerdo a la charla, reviviera detallada y minuciosamente lo acontecido en el conflicto bélico.

Varios excombatientes de la guerra de Malvinas aun participan frecuentemente de actos y homenajes en los que se conmemora la participación de sus compañeros caídos, comentando anécdotas o sencillamente describiendo su participación en la guerra. Véase al respecto Patierno (2011).

${ }^{12}$ Existe un reclamo en Argentina, sostenido por los familiares de los soldados caídos en la guerra de Malvinas, por la extradición de los restos de los soldados no reconocidos que se encuentran enterrados como NN, es decir sin nombre (del latín Nomen Nescio). Los fundamentos de este reclamo, además de la cuestión de la soberanía, radican en que los cuerpos de los soldados yacen en tumbas improvisadas sin un nombre tallado en las correspondientes lápidas. En una visita a las islas en el año 2010, efectivamente pude observar que muchas de las tumbas (ubicadas en el cementerio de Darwin, un páramo situado a cuarenta kilómetros de la ciudad principal) tenían impreso el lema: "Soldado argentino solo conocido por Dios". La intención de asociar un nombre al cuerpo que yace producto de un enfrentamiento armado, evidencia la necesidad de otorgarle un sentido a la muerte y de reunir el cuerpo muerto "en acción" con una historia digna de revivir a través del discurso.
} 
hombres; por el contrario, señala frustraciones inherentes a la acción y la pluralidad. Di Pego propone analizar las frustraciones que menciona Arendt en tres aspectos fundamentales: el carácter anónimo de la acción, su imprevisibilidad y su irreversibilidad. El anonimato de la acción se evidencia en la historia que un agente deja tras de sí: a pesar de la permanencia de los documentos y los monumentos, la historia trasciende los sujetos puesto que un agente puede llevar a cabo, iniciar o comenzar una obra, pero no pude ejercer control alguno sobre la misma. La historia, como resultado de la concatenación ilimitada de acciones y palabras, carece de un autor o productor, siendo solo posible a lo sumo identificar un agente que inicia una serie de sucesos y que, al mismo tiempo que actúa, padece sus consecuencias (Di Pego 2015: 236). En esta lógica, la historia no tendría ni un comienzo ni un fin establecido, y el historiador sencillamente cumpliría la función de "narrar" determinados acontecimientos considerados relevantes por la comunidad académica pertinente. Sólo cuando en la historia futura ocurra un nuevo acontecimiento, el fin se revelará como un inicio a los futuros historiadores (Arendt 2008: 41). Siguiendo a Di Pego:

En la medida en que toda acción genera reacciones y nuevas acciones que inician una cadena ilimitada de consecuencias, la acción resulta anónima puesto que carece de un "autor" que pueda controlar su desenlace. La acción comprende así dos momentos susceptibles de ser diferenciados: un comienzo que puede ser realizado por una sola persona, y un desenlace en el que indefectiblemente actúan muchas personas (2015: 243).

Con respecto a la imprevisibilidad de la acción y en relación con la cita mencionada anteriormente, es importante destacar que la pluralidad es una condición para que toda acción se lleve a cabo. No es posible realizar una acción en aislamiento, requiere de la interacción, de la participación de otros; no tendría sentido presentarse con la particularidad que nos caracteriza a cada uno sino hubiera otros agentes dispuestos a reconocernos como sujetos únicos. La pluralidad que implica estar entre los hombres genera consecuencias ilimitadas y no previstas por el actor (Di Pego 2015: 243). Las instituciones se presentan en la modernidad como un intento por controlar las acciones, o al menos generar un marco normativo que ayude a recortar su imprevisibilidad; sin embargo, la estabilidad que ofrecen las instituciones es relativa, ya que la inestabilidad inherente a la vida humana suele prevalecer por sobre todo intento de conservación.

La tercera frustración vinculada a la acción se refiere a la irreversibilidad; esta afirmación supone que las palabras y acciones realizadas no pueden deshacerse ni 
modificarse (Di Pego 2015: 244). Sin embargo, la acción misma implica un paliativo para esta condición. A través del perdón, es posible generar una nueva acción capaz de otorgarle un nuevo significado a una acción pasada. Esta sería la alternativa a lidiar eternamente con las consecuencias imprevistas de una acción. Únicamente esta cualidad humana permite que una acción pueda deshacer otra acción anterior (con el objetivo de alivianar las consecuencias no deseadas de aquella acción realizada en el pasado):

El perdón (ciertamente una de las más grandes capacidades humanas y quizás la más audaz de las acciones en que intenta lo aparentemente imposible, deshacer lo que ha sido hecho, y logra dar lugar a un nuevo comienzo allí donde todo parecía haber concluido) es una acción única que culmina en un acto único (Arendt 2008: 300).

Un intento por otorgar "estabilidad" frente a la imprevisibilidad de la acción puede hallarse en la promesa; esta supone la intención de orientar las acciones futuras en una dirección que otorgue sentido a los esfuerzos invertidos. Sin la promesa no habría perspectiva de futuro, y las acciones de los hombres vagarían desligadas de la oportunidad de unir fuerzas para la realización de proyectos comunes; este es uno de los requisitos fundamentales para el funcionamiento de la política.

El perdón y la promesa, por otro lado, requieren siempre de la presencia de otros, no tendría sentido perdonarse o prometerse algo a sí mismo. Así,

El perdón y la promesa son facultades que dependen de la pluralidad, del estar entre los hombres, porque el perdón y la promesa ante uno mismo carecen de realidad, ya que nadie puede perdonarse a sí mismo o sentirse ligado a una promesa que se hizo a sí mismo (Di Pego 2015: 249).

\subsection{El saber y el hacer en la política}

Para Arendt, la acción es parte fundamental de la vita activa, ésta es la actividad más vinculada con el pensar y el hacer, puesto que, a diferencia de las otras actividades, no supone obligadamente la mediación de las necesidades o de la materia. Mientras que la labor pone el acento en las limitaciones intrínsecas al ser humano en su vida biológica y el trabajo hace hincapié en el mundo material producto del artificio del homo faber, el principio de la acción implica la palabra y el acto. Para la autora, resulta fundamental que la acción esté acompañada de la palabra (puesto que la palabra implica un actor determinado). Por tal motivo, y teniendo en cuenta que la acción es personal, podemos afirmar que toda separación entre palabra y acción conlleva un objetivo, una intencionalidad política. 
Arendt identifica en la filosofía griega, y particularmente en la obra de Platón, el origen de la separación entre saber y hacer. Con esta segregación arbitraria, que favorece los intereses políticos de la clase dominante, se pretendió legitimar la función de algunos hombres -al mismo tiempo, esta separación sirvió a la protección de los políticos y a la legitimación de la esclavitud, elementos fundantes de la política y la vida en la polis. ${ }^{13}$ Mientras que los hombres destinados a pensar gozaban de determinados derechos asociados a su sabiduría, ellos mismos creaban las condiciones ideológicas para que otros hombres, destinados al hacer, tuvieran la obligación de "no intervenir" (ni en las decisiones políticas, ni en la erudición de los filósofos). Para la función social vinculada al hacer, los griegos destinarían el concepto de artesanía, tarea asociada a la actividad del trabajo y, en la época moderna, a la producción fabril. Respecto de esta separación entre el saber y el hacer, Arendt señala lo siguiente:

La separación platónica de saber y hacer ha quedado en la raíz de todas las teorías de dominación que no son simples justificaciones de una irreductible e irresponsable voluntad de poder. Debido a la conceptualización y clarificación filosófica, la identificación platónica de conocimiento con mando y gobierno y de acción con obediencia y ejecución rigieron las primeras experiencias y articulaciones de la esfera política y pasó a ser autoritaria para toda la tradición del pensamiento político (Arendt 2014: 245).

Esta separación se mantiene a lo largo del oscurantismo, con una diferencia respecto de la legitimación en los espacios donde el ejercicio del poder requiere de la fragmentación entre saber y hacer. En lugar del filósofo, es el sacerdote quien ocupa la tarea de pensar, y amparado en un supuesto poder divino goza de privilegios en relación a otros mortales. El artesano mantiene su accionar vinculado a la producción de manufacturas, y el esclavo (o individuo proveniente de un territorio conquistado) continúa llevando bajo sus espaldas las tareas que sus amos le demanden. De esta manera, la estructura dual entre decir y hacer sostiene las bases del poder de la fe católica en occidente, poniendo la religión en el lugar que ocupaba la política griega y asignando funciones con base en la fragmentación entre pensamiento y acción.

Un ejemplo descripto en el primer capítulo de Vigilar y castigar (Foucault 2002) hace referencia a esta separación de funciones a la hora de aplicar los castigos por parte de las autoridades religiosas (fundamentalmente en el período comprendido entre los siglos

\footnotetext{
${ }^{13}$ Como bien señala Di Pego, Arendt no toma la polis griega como un ideal, sino que la recupera como una experiencia política del pasado que permite repensar sentidos olvidados de la política (Di Pego 2015: 217).
} 
XV y XVI). En el desarrollo del capítulo, Foucault detalla los procedimientos de las torturas públicas a las que eran condenados aquellos que, según los funcionarios de la inquisición, eran culpables de algún delito en contra de la doctrina cristiana. Lo relevante de este ejemplo es que los encargados de enjuiciar y tomar las decisiones sobre el destino de los castigados (es decir, los asociados a la tarea del pensar) no son los mismos que los encargados de encerrar al condenado, ni son los mismos que se ocupan de su ejecución. La mano del verdugo, encargada de cercenar cabezas o accionar la horca, aplica el castigo, pero no tiene participación alguna en el enjuiciamiento del condenado. El pensar asociado a la decisión respecto de la pena que debe aplicarse al procesado, corresponde al clérigo de mayor jerarquía. Esta estructura se mantiene en la época moderna con el rol del juez en lugar del sacerdote y la prisión con todo su montaje institucional en lugar de la horca y del verdugo.

Para entender más en profundidad de qué manera funciona esta noción de fragmentación, tomemos el ejemplo de los griegos y su legitimación de la función de los esclavos. En esta relación asimétrica basada en la posesión de un humano y su capacidad de laborar por otros, es posible rastrear uno de los usos políticos asociados a la diferenciación entre el pensar y el hacer. Las tareas de los esclavos se centraban en mitigar las labores requeridas por sus amos -en relación a la complejidad de la vida humana, el esclavo carecía de toda particularidad inherente a su condición de dependencia-, y por lo tanto el esclavo no poseía ninguna facultad en la organización de la vida en la polis, sino que se encontraba restringido a los requerimientos de sus poseedores. Para los griegos este era el equivalente a un animal domesticado que no solo debía cargar con el peso de su propia labor, también debía realizar la labor impuesta por otros que, amparados políticamente a través de la legitimación de su discurso, se ubicaban por encima de él. Según Arendt, "La degradación del esclavo era un golpe del destino y un destino peor que la muerte, ya que llevaba consigo la metamorfosis del hombre en algo semejante al animal domesticado" (Arendt 2014: 245).

Es posible rastrear en el mundo griego un desprecio por los oficios y la esclavitud, desprecio que radicaba en su falta de trascendencia, más allá de que se los considerara como actividades necesarias para la vida en la polis. Para el griego realizado -aquel ciudadano pleno de derechos y libertades-, la realización de alguna de estas tareas intrascendentes equivalía a padecer una condena. 


\subsection{Los riesgos asociados al puro hacer}

A partir de la separación platónica entre el pensar y el hacer, se abrieron las puertas de un tipo de política más vinculada al hacer, es decir, a la búsqueda del control de las acciones, tomando el modelo de la fabricación como parámetro de referencia. Sobre las consecuencias que esta separación trajo en los ideales fundantes de la política moderna en occidente, Di Pego afirma lo siguiente:

El reemplazo platónico del actuar por el hacer impone el modelo de la fabricación, según el cual se asegura cierta previsibilidad pero también se acepta la violencia como parte del proceso, al tiempo que hace posible la reversibilidad a través de la destrucción del producto. Al concebir la política de este modo no solo se neutraliza la pluralidad, sino que también se introducen la violencia y la destrucción en el horizonte político (Di Pego 2015: 249).

Arendt resalta que la política en la modernidad se encuentra peligrosamente asociada al hacer, más específicamente a un hacer irreflexivo, sistematizado, producto de la burocracia y el automatismo aplicado a la esfera de los asuntos humanos. Al desvincular el hacer de la contemplación, y priorizar las actividades asociadas a la vita activa, la política se encuentra ajena a la novedad e imposibilitada de incluir alternativas, y se acerca más bien a un modelo político amparado en la estabilidad artificial del homo faber y en su violenta relación con la naturaleza. Como afirma Arendt,

Sólo la convicción de la Época Moderna de que el hombre puede conocer lo que hace, que sus capacidades pretendidamente más elevadas dependen de la fabricación y que, por lo tanto, es profundamente homo faber [...], pusieron de manifiesto las implicancias mucho más antiguas de la violencia inherentes a todas las interpretaciones de la esfera de los asuntos humanos como esfera de la fabricación (Arendt 2014: 248).

Al interpretar la política como algo factible, los medios más adecuados para llevarla a cabo no serían otros que aquellos "violentamente justificados". Tras los resultados de las revoluciones llevadas a cabo en occidente entre los siglos XVIII y XIX, con la consecuencia de la creación de los Estados-naciones que hoy conocemos -cuyo funcionamiento e ideologías se impusieron a partir del uso de la violencia-, la política quedó estrechamente emparentada al hacer. Este modo de "hacer política" requiere, para su expansión, no solo un cuerpo de ideas capaz de legitimar el lugar del hombre por sobre la religión, sino también una glorificación de la violencia, interpretada como medio necesario para ejercer la política. 
La mejor prueba de la persistente y triunfal transformación de la acción en un modo de hacer nos la da la terminología del pensamiento y de la teoría política, que hace casi imposible tratar estas materias sin emplear la categoría de medios y fines y discutir en términos de instrumentalidad (Arendt 2014: 248).

En la época moderna, cualquier medio es admitido bajo el amparo que implica la consecución de un fin. En este sentido, la violencia resulta ser el fin más efectivo, incluso más efectivo que la violencia inherente a los elementos de la naturaleza (al menos en su poder destructivo). Los sistemas de gobierno amparados en el uso de la violencia, si bien sólo prevalecieron durante períodos breves de la modernidad, dejaron tras de sí una marca de destrucción imposible de desterrar de los asuntos humanos.

Es esperable hallar a lo largo de La condición humana una fuerte crítica a los sistemas de gobierno amparados en el uso de la violencia; esta quizás sea la respuesta filosófica de Arendt frente a los abusos políticos que ella misma sufrió producto de su origen judío. La respuesta de la autora muy posiblemente se encuentre en la exaltación de la acción, interpretada como característica propia de los hombres libres. Si bien es una lectura personal, la acción es el medio a través del cual Arendt propone luchar frente a las imposiciones de determinadas organizaciones políticas, y más fundamentalmente en contra de aquellas obsesionadas con el control de las libertades. La acción se encuentra siempre atada al sistema de gobierno imperante y a los mecanismos de control que dicho gobierno ejerce sobre su población. En un sistema de gobierno totalitario, donde la decisión individual, la novedad, son sólo fantasías, el concepto de acción propuesto por Arendt carecería de sentido, puesto que las consecuencias de todo acto serían predecibles. En otras palabras, el totalitarismo suprime la pluralidad y con ello toda posibilidad de acción. Dado que toda acción implica consecuencias incalculables, la única forma de coartar esta posibilidad es a través de la predicción, es decir, del control de dichas consecuencias fundamentalmente anulando la pluralidad y ejerciendo una dominación total sobre las personalidades y los cuerpos. Pensar las implicancias de la acción humana en el sentido que le otorga Arendt, por el contrario, es pensarlas asociadas a un carácter ilimitado, impredecible e irreversible. "El hecho de que el hombre sea capaz de acción significa que cabe esperarse de él lo inesperado, que es capaz de realizar lo que es infinitamente improbable. Y una vez más esto es posible debido sólo a que cada hombre es único" (Arendt 2014: 202). 


\subsection{Conclusiones del apartado}

Ese "hombre único" mencionado en la cita precedente no se reduce solo a su presencia física; la novedad que acompaña a la condición humana no implica únicamente una nueva vida en términos biológicos -como si fuese posible reducir la humanidad a un conjunto de órganos, huesos y articulaciones que hay que alimentar y cuidar a lo largo de su "natural" maduración. La novedad supone el ingreso del discurso y de la acción en un mundo conformado por otros seres humanos, que se mueven y actúan sujetos a determinados órdenes políticos, los cuales establecen determinados marcos de participación. En otras palabras, un nuevo sujeto, además de un cuerpo con las características heredadas genéticamente y por lo tanto -hasta el momento- imposibles de cambiar, implica nuevos deseos, nuevos temores, nuevas opiniones, nuevas formas de movimiento y expresión; y esto es posible siempre y cuando los hombres que habitaban el mundo antes de la llegada "del nuevo", permitan que esto suceda. Ese permiso a la novedad se encuentra impreso en el tipo de organización política, y en el tipo de educación que cada sociedad asume y legitima como propia y adecuada. Alguien que recién ingresa al mundo no tiene a su alcance ninguna posibilidad de acción, si los que habitaban el mundo previo a su llegada no dejan lugar alguno a la participación de las nuevas generaciones. A continuación se desarrollarán algunas problemáticas pertinentes a lo hasta aquí desarrollado, a partir de una profundización en los conceptos de natalidad y educación. 


\section{Capítulo 3. Reflexiones en torno a la educación del cuerpo}

El hecho de que el hombre sea capaz de acción significa que cabe esperarse de él lo inesperado, que es capaz de realizar lo que es infinitamente improbable. Y una vez más esto es posible debido a que cada hombre es único, de tal manera que con cada nacimiento algo singularmente nuevo entra en el mundo.

(Arendt, H. La condición humana)

\subsection{Palabra y acto como segundo nacimiento}

El concepto de natalidad es de fundamental importancia en la teoría de Arendt. A diferencia de la concepción tradicional de nacimiento, asociada al momento del parto y a los primeros momentos del hombre en el mundo, la autora considera la participación activa del hombre a través de la acción y la palabra como el momento en que verdaderamente un sujeto ingresa en la esfera de los asuntos humanos. Centrar la atención únicamente en el nacimiento biológico sería reducir la existencia humana a su presencia física; ésta es solo una parte de la vida humana. En la lógica de Arendt, el hombre requiere de la acción y la palabra para introducir la novedad en el mundo. Manuel Cruz, en la introducción al libro de Arendt titulado De la historia a la acción, sostiene:

Los hombres son seres que se fijan objetivos, se proponen fines. Es precisamente este poder de iniciativa el que queda designado a través del término natalidad. La natalidad expresa el fundamento ontológico de cada individuo humano. Todo hombre es único porque, como se sostiene en la condición humana, con cada nacimiento algo singularmente nuevo entra en el mundo (Arendt 2008: 20).

Luego del nacimiento biológico, del inicio de nuestra presencia física en el mundo, transitamos por él compartiendo necesidades y labores con otros humanos, al mismo tiempo que nos diferenciamos de cada uno. Más allá de la apariencia corporal, son el discurso y la acción los que revelan la capacidad de ser distinto, es a través de estas capacidades que los seres humanos se presentan unos a otros. Cada uno es diferente a cualquier otro que existe, existió o existirá, y esa distinción requiere del discurso y de la acción para el entendimiento, para la superación de adversidades y para la relativa previsión del futuro. Esto no ocurre en ninguna otra actividad de la vita activa: los hombres pueden obligar a otros a que laboren por ellos, e incluso decidir sobre el uso y el disfrute de las cosas del mundo, pero nadie puede reemplazar la acción y el discurso de otro ser humano. Incluso si alguien se hallara imposibilitado de llevar a cabo sus propias acciones, afectado 
por una enfermedad o un estado de coma, y un familiar debiera encargarse de tomar las decisiones respecto de su tratamiento, serían la acción y el discurso del familiar -y no del sujeto impedido en sus plenas funciones- los que decidirían respecto del destino de la persona afectada. Por más esfuerzos que pongamos en intentar recrear el discurso y la acción de otro ser humano, siempre serán nuestras acciones las que se harán presentes en mayor o menor medida afectando cualquier intento de mediación.

Con palabra y acto nos insertamos en el mundo humano, y esta inserción es como un segundo nacimiento, en el que confirmamos y asumimos el hecho desnudo de nuestra original apariencia física. A dicha inserción no nos obliga la necesidad, como lo hace la labor, ni nos impulsa la utilidad, como es el caso del trabajo (Arendt 2014: 201).

Como se mencionó anteriormente, la acción requiere de la palabra, ya que sin el acompañamiento del discurso la acción carecería del sujeto. Y la palabra implica la acción, ya que la pura acción se vería fácilmente tentada por la efectividad de la violencia. Si atendemos a la afirmación de Arendt a este respecto: "la violencia, a diferencia del poder, es muda; comienza allí donde acaba el discurso" (Arendt 2008: 30), ${ }^{1}$ podemos inferir lo que sucedería si la balanza se inclinara hacia la pura acción. Probablemente nos hallaríamos bajo los efectos de una represión, como la que vivió gran parte de la sociedad occidental del siglo $\mathrm{XX}$ bajo los formatos del totalitarismo. Si, por el contrario, nos halláramos en una sociedad guiada exclusivamente por el discurso, ésta difícilmente podría llegar más allá de un eterno debate, sin posibilidad alguna de plasmar las ideas en proyectos ejecutables.

Un sistema de gobierno que prioriza y promueve la natalidad es un sistema de gobierno "sano", puesto que deja lugar a la novedad, al accionar de los hombres. ${ }^{2}$ Esta es una de las contradicciones que arrastra la educación moderna tradicional, ¿cómo un

\footnotetext{
${ }^{1}$ Podemos observar, a lo largo de varios textos de Arendt, la importancia de que acción y discurso transiten juntos la misma senda. Cuando alguno de estos elementos se separa, se corre el riesgo de que surjan organizaciones políticas de tipo extremista. En relación al ejercicio de la pura acción, estaríamos en presencia de organizaciones vinculadas al uso explícito de la violencia; las políticas basadas exclusivamente en el discurso, en cambio, no serían más que infinitas promesas.

${ }^{2}$ El film Hijos de los hombres, dirigido por Alfonso Cuarón, da cuenta de lo que sucedería en el mundo si los humanos perdieran la capacidad de procrear. En un enfoque apocalíptico, la desesperanza que implicaría la desaparición de las nuevas generaciones conllevaría un incremento en los enfrentamientos bélicos, la propagación de actos terroristas y el incremento de los suicidios (incluso llevados a cabo en masa). Si bien esta adaptación al cine de la novela The Children of Men de Phyllis James cumple con los requisitos extremistas de una película apocalíptica, y por lo tanto sus escenas tienen una finalidad asociada al caos y la anarquía, no deja de sorprender el acercamiento con las ideas de Arendt respecto de la importancia que tiene la natalidad en las organizaciones políticas. La natalidad, tanto en su momento inicial asociado al nacimiento biológico como en su segundo momento vinculado a la participación activa, resulta de suma importancia si se pretende asegurar un presente y futuro pacífico en la vida de los hombres.
} 
instrumento creado por los Estados modernos, destinado a la regulación de lo nuevo y vinculado al más dominante conservadurismo, puede atender a la novedad que conllevan las nuevas generaciones? Esta situación pone en evidencia una crisis inherente a la tensión que genera la regulación y homogeneización de los nuevos en manos de "los viejos" -es decir, de las generaciones encargadas de preservar el mundo que conocen. Arrojar los jóvenes a su suerte sería dejarlos a merced del desamparo que supondría no acceder a los saberes heredados de las generaciones previas. En este caso, las nuevas generaciones quedarían desprovistas de las ventajas que supone afrontar los obstáculos de la existencia humana con el respaldo de la sabiduría desarrollada previamente a lo largo de las sucesivas generaciones.

Para Arendt, la educación es una estrategia política que se inscribe entre los recursos de dominación; a través de la transmisión de ciertas tradiciones mediadas por la autoridad del adulto enseñante, se intenta ejercer el dominio de la población desde las edades más tempranas. En la compilación de ensayos titulada Entre el pasado y el futuro, publicada a fines de la década de 1960, Arendt destaca lo siguiente en relación a la educación y su incumbencia en la política: "La palabra educación tiene un sonido perverso en política; se habla de la educación, pero la meta verdadera es la coacción sin el uso de la fuerza" (Arendt 1996: 188).

Hablar de educación implica necesariamente apelar a la idea de un doble conservadurismo. En primer lugar se busca proteger a los más jóvenes de los riesgos que supone el libre albedrío y un destino ligado a la incertidumbre. Al mismo tiempo, la función conservadora intenta mantener las tradiciones frente a la novedad y los intentos de cambio que conllevan las nuevas generaciones. En sus propios términos:

El conservadurismo, en el sentido de la conservación, es la esencia de la actividad educativa, cuya tarea siempre es la de mimar y proteger algo: al niño, ante el mundo; al mundo, ante el niño; a lo nuevo, ante lo viejo; a lo viejo, ante lo nuevo (Arendt 1996: 204).

\subsection{El saber de la mente y el hacer del cuerpo en el campo de la educación}

En el caso de la educación -inaugurada como sistema burocrático a la par de la expansión de los Estados-nación-, el dualismo entre saber y hacer, vigente en occidente desde la antigua Grecia, se vio plasmado en una división de prácticas hacia el interior de su propia 
organización institucional. Se otorgó mayor interés y alcance a los saberes vinculados con el pensar, pero no con el pensar en el sentido de la reflexión y del entendimiento, sino con un pensar sistematizado bajo el amparo del humanismo, de la burocratización y desprovisto de toda imaginación y creatividad admisibles. El saber en la educación moderna, y particularmente en la educación impartida en las escuelas, se solventó gracias a su sistematización; tarea necesaria para la construcción y afianzamiento de los Estados modernos.

La conformación de los Estados modernos se basó en la lógica del hacer, exacerbando la violencia como el medio más eficaz para su afianzamiento. La revolución fue el modelo político por excelencia. Este tipo de violencia, estrechamente vinculado al ejercicio de la política, supone que un país se hace al igual que un producto se fabrica en una línea de producción. El hacer concebido en términos de trabajo se volvió una de las categorías fundamentales de la filosofía política moderna, y la acción misma se volvió indistinguible de ese hacer instrumental (Di Pego 2015: 248). Esta es la lógica que atravesó la creación de los sistemas educativos modernos: los sujetos que ingresan en estos sistemas, a partir del tránsito por varios niveles -análogo al proceso en el que se elabora un producto-, adquieren los saberes necesarios para desenvolverse en el mundo (o, más exactamente en un mundo ideal sostenido originalmente por los nacionalismos decimonónicos).

Podemos rastrear en el discurso de Arendt un vínculo entre la tarea docente y las actividades asociadas a la labor, uno de los componentes (recordemos) menos reflexivos de la vita activa. Al igual que un obrero, un oficinista o el escritor de un periódico asalariado, un docente es un reproductor automatizado, alguien que se preocupa por cumplir una función en un horario y espacio determinados. Al mismo tiempo, el docente empleado por el Estado se transforma en rehén de sus propias necesidades vitales, que peligran constantemente en manos de un empleador con intereses que van más allá de la lectoescritura, de las operaciones abstractas o de la ejercitación del cuerpo. En una doble estrategia de dominio, los Estados modernos se garantizan el control ideológico de sus poblaciones explicitando los contenidos a transmitir y reduciendo las tareas docentes a la simplicidad de la labor, entendida como una actividad cíclica y rutinaria. En esta lógica, los docentes-laborantes son incapaces de pensar, o al menos incapaces de pensar sobre sí 
mismos, puesto que sus tareas se encuentran atadas a las decisiones de los que "piensan" la educación, o, mejor dicho, de aquellos a quienes el Estado les delegó la tarea de pensar la educación.

En esta fragmentación, los saberes vinculados al hacer, ubicados en un segundo plano de relevancia con respecto al pensar, y sostenidos fundamentalmente en los principios del trabajo, adquieren el formato de la relación entre el hombre y la naturaleza. A partir de la modernidad, es difícil encontrar un vínculo entre los saberes asociados al pensar y al hacer; no se piensa sobre lo que se hace, ya que el hacer no requiere pensamiento (más allá del necesario para poner en marcha el movimiento requerido, cuyo mecanismo fisiológico sería involuntario).

La educación moderna dejó en ese segundo plano las actividades vinculadas al hacer, fundamentando esta posición en un saber científico que ve al cuerpo como un objeto a analizar en un laboratorio. El cuerpo que se mueve no es el mismo que piensa. De hecho, el ser pensante no implica necesariamente un cuerpo, la función de la mente es una función "sin sustento"; se libera de esa carga innecesaria que implica el cuerpo, como si el pensamiento ideal se hallara fuera de éste. De esta manera, la palabra queda desprovista de un cuerpo que la sostenga, y en cambio se transforma en el efecto de la vibración de las cuerdas vocales. De igual modo, el pensar es relacionado directamente con las funciones del cerebro; esta es la síntesis en la que descansa el materialismo asociado al saber, una respuesta al requerimiento constante de occidente por materializar todo en un mundo que solo adquiere sentido alrededor de lo tangible, de lo observable, de lo medible.

El saber hecho cosa no requiere de un cuerpo, más bien requiere de un mundo en el que su lógica material posea sentido, y ese mundo se construye metódicamente con instrumentos como la educación. En esta lógica, no es una sorpresa que, en la repartición de horas para las asignaturas de una escuela promedio en Argentina, solo una materia se encargue del cuerpo, comúnmente denominada Educación Física -la cual, por lo demás, ni siquiera se encarga del cuerpo, al menos en la complejidad que le otorga Arendt. El cuerpo de la Educación Física es un cuerpo material, tangible y fragmentado por excelencia. Desde su nacimiento fundamentado en los saberes de la biología y la fisiología, el cuerpo de la educación, al igual que el animal de la zoología o el mineral de la química, descansa en una existencia irreflexiva que encuentra su explicación alrededor de un conjunto de músculos, 
huesos y articulaciones. Es en estos componentes objetivables, que el cuerpo encuentra el sentido que la sociedad moderna le demanda.

El tiempo destinado al trabajo del cuerpo en el campo de la educación no es más que un reduccionismo al estímulo de sus capacidades motoras; de igual modo que un biólogo estimula el crecimiento de una planta, los encargados del cuidado y desarrollo del cuerpo, amparados en la exclusividad del hacer, cuentan con técnicas específicas para el perfeccionamiento de sus cualidades motrices. El hacer se transforma así en una práctica excluyente. Fuera de los espacios destinados al hacer del cuerpo en la educación, no hay posibilidad alguna de recrear este vínculo. En relación con Arendt, podemos afirmar que los sistemas educativos han creado un hacer exclusivo, amparado en una noción de cuerpo que se encierra en su propia labor, y se esfuerza por la máxima eficacia de su trabajo.

Este cuerpo "creado" por los sistemas educativos es una de las principales preocupaciones de Crisorio, que bajo el amparo de una reinterpretación de las ideas comúnmente asociadas al cuerpo -constituyendo a tal efecto un campo de investigación denominado Educación Corporal-, ${ }^{3}$ llevó a cabo la minuciosa tarea de rastrear los discursos fundantes de este modelo de "cuerpo moderno", remontándose hasta sus orígenes grecorromanos. Al indagar aquellos discursos, dualismos y significados que atravesaron al cuerpo en occidente desde la antigua Grecia hasta su llegada al campo de la educación moderna, Crisorio asume una postura crítica frente a la supuesta naturaleza innata del

\footnotetext{
${ }^{3}$ En el caso de Argentina, recién a mediados de los '90 algunos profesores de Educación Física -entre los que se destacan los aportes de Ricardo Crisorio y Marcelo Giles- comenzaron a pensar cuestiones históricas y políticas vinculadas al cuerpo humano, desviando la mirada del típico abordaje biologicista que reducía el análisis del cuerpo y sus prácticas al saber de las Ciencias Naturales, particularmente al de la Biología y la Medicina. Esta ruptura en los modos tradicionales de abordar el concepto de cuerpo se hizo explícita recién a partir del año 2001, luego de varias luchas políticas en búsqueda de una legitimación académica, con la creación de la carrera de posgrado denominada Maestría en Educación Corporal. Luego continuó su recorrido hasta contar con un centro de investigación propio en las dependencias de la Universidad Nacional de La Plata, denominado Centro Interdisciplinario Cuerpo, Educación y Sociedad (CICES), el cual funciona desde el año 2012 en la Facultad de Humanidades y Ciencias de la Educación (y es dirigido, al momento de la confección del presente trabajo, por Ricardo Crisorio). Una breve cita de la carta de presentación del Centro de Investigación da cuenta de este cambio de sentido respecto de los modos tradicionales en el que se llevaron a cabo diversas investigaciones vinculadas al cuerpo humano: "Las líneas de trabajo que integran el CICES convergen, directa o indirectamente, en torno a la exploración de los mecanismos por los cuales nuestra sociedad piensa el cuerpo y lo educa como lo hace, con el propósito de generar formas que permitan pensar estos problemas de modo diferente. (...) En resumen, plantea la necesidad e importancia de la investigación crítica desde una perspectiva epistemológica interdisciplinaria y relacional (ni esencialista ni relativista, ni en la que cada hecho, fenómeno o concepto pueda hallar su significación aisladamente)" (Carta de presentación del Centro Interdisciplinario Cuerpo, Educación y Sociedad, disponible en: http://www.fahce.unlp.edu.ar//idihcs/cices/presentacion).
} 
cuerpo humano. ${ }^{4}$ En un pasaje destinado a la explicación de los fundamentos de la Educación Corporal, Crisorio sostiene:

Lejos de pertenecer a la naturaleza, el cuerpo es de la cultura y tiene una historia en la que hay que indagar, no para saber qué o cómo ha sido sino para elaborar un concepto de cuerpo nuevo más que un concepto nuevo de cuerpo (Crisorio 2014: 170).

Las disciplinas encargadas de tomar el cuerpo como objeto de estudio, y particularmente la Educación Física, se preocuparon por el hacer -y por añadidura, por la búsqueda de un hacer racional, científico, obsesionado con la eficiencia del movimiento humano. En vez de rastrear los discursos legitimados a lo largo de la historia, o analizar las implicancias políticas que sostienen determinadas prácticas corporales, la Educación Física funcionó, y lo continúa haciendo, como apéndice de la medicina, ${ }^{5}$ ocupada en legitimar su campo con el uso de un lenguaje anátomo-fisiológico. Así, las investigaciones que propone Crisorio estarían destinadas a desnaturalizar este vínculo recurrente entre los discursos de la educación del cuerpo y los saberes asociados a la salud:

Saber del cuerpo en tanto algo distinto del organismo, requiere investigaciones por entero distintas de las de la fisiología, la neurología o la psicología. Requiere indagar, por ejemplo, precisamente cómo, y si fuera posible por qué, en nuestra cultura el cuerpo ha devenido unidad orgánica, dado que hay pruebas suficientes de que no siempre lo fue (Crisorio 2010: $6)$.

Desde mi punto de vista, el problema de esta organización de la educación -y por ende también de la política-, vinculada a la transmisión de habilidades necesarias para habitar el mundo de manera eficiente y "saludable" (principios explícitos en cualquier programa o currículum de Fisiología, Biología o Educación Física), radica en lo que queda por fuera de este reduccionismo a sólo unas determinadas actividades. En términos de Arendt, esta educación del cuerpo estaría íntimamente asociada con las actividades agrupadas bajo los

\footnotetext{
${ }^{4}$ En un minucioso recorrido por los discursos que atravesaron el cuerpo desde el Renacimiento hasta la actualidad, Crisorio describe la relación entre los conceptos cuerpo y naturaleza del siguiente modo: "a mediados del siglo XVIII aparecieron en la educación sistemas de ejercicios y juegos corporales ligados a la promoción y mantenimiento de la salud, poniendo al cuerpo del lado de la naturaleza (...). Desde su nacimiento y hasta ahora, la Educación Física ha pensado la vida de los seres humanos y a los seres humanos en conexión inmediata con la naturaleza, tendiendo a estudiarlos a través de la psicofísiología o de una naciente sociobiología, atribuyendo los comportamientos humanos, individuales y sociales, a dinámicas ligadas en última instancia a las necesidades evolutivas de una especie" (Crisorio 2010: 10-11).

5 Desde mi punto de vista, y en relación con la teoría de Arendt, la Educación Física constituye la fusión de las técnicas asociadas al trabajo - con la consecuente demanda de un cuerpo eficiente, útil y económico-, y la legitimación del discurso médico asociado a la salud, es decir, ligado al resguardo de la labor. Esto legitimaría una educación del cuerpo al servicio del animal laborans, justificando la realización de prácticas corporales con el objetivo último de mantener un cuerpo sano.
} 
conceptos de labor y trabajo. En relación a la labor, el humano en crecimiento ${ }^{6}$ debería aprender aquellas habilidades "naturales" que le garantizarían una vida eficiente desde el punto de vista biológico (la mejor alimentación, el modo de vestirse, la manera de dormir, etcétera). De acuerdo a la lógica del trabajo, los habitantes de este mundo artificial, es decir, del mundo colectivamente construido por ideologías basadas en el intercambio de productos, deberían recibir una educación basada en la valoración de estas ideologías fundantes $\mathrm{y}$ en el disciplinamiento del cuerpo requerido para el trabajo. Más específicamente, la educación debería basarse en el valor del trabajo como actividad moralmente correcta y la búsqueda de la máxima eficacia en todos los aspectos de la vida. El problema de esta materialización de saberes, en términos arendtianos, estaría centrado en la ausencia de una educación asociada a las posibilidades que brinda la acción, vinculada por lo tanto al ejercicio de la libertad y la exploración de la potencialidad humana. En la educación moderna, el cuerpo se moldea al igual que un producto en una cadena fabril: pasa por varios niveles y llega a un producto legitimado como eficaz, económico y preparado para habitar el mundo de determinada manera -sobre este tema se ampliará en el apartado siguiente.

En un sentido estricto, el término educación, como lo conocemos a partir de la modernidad, no podría relacionarse con la idea de acción propuesta por Arendt, puesto que circulan por vías significativamente opuestas. Mientras que la educación pretende coartar libertades -función alternativa y más eficiente que el uso de la fuerza explícita (debido a los riesgos que la violencia conlleva respecto del ejercicio del poder y la legitimidad) -, la acción, concepto más asociado a la idea de libertad, intenta explorar las potencialidades de la condición humana sin recortes ni limitaciones, más allá de las inherentes a la misma humanidad. Pensar la educación en este sentido supondría deshacerse de la coacción que lleva impreso dicho término; y, muy por el contrario, dirigir los esfuerzos hacia la exploración y el refuerzo de la potencia humana.

\footnotetext{
${ }^{6}$ La educación para Arendt está dirigida exclusivamente a las generaciones jóvenes; cuando se pretende educar a los adultos en realidad se estaría ejerciendo una intención explícita de dominio. En sus términos: "La educación no debe tener un papel en la política, porque en la política siempre tratamos con personas que ya están educadas. Quien quiera educar a los adultos en realidad quiere obrar como su guardián y apartarlos de la actividad política (...)" (Arendt 1996: 188).
} 
Arendt también aporta herramientas conceptuales para el análisis de la efectividadcaducidad de los sistemas educativos modernos. A continuación nos detendremos en el libro de Arendt titulado Entre el pasado y el futuro, donde analiza la educación moderna y su crisis como algo inherente a su propio funcionamiento -crisis justificada en una exacerbada burocracia, producto de la estatización de la educación, y en la influencia de una crisis general de la sociedad moderna basada en el detrimento de la autoridad.

\subsection{La crisis de la educación moderna}

El problema que señala Arendt respecto de la educación es que los sistemas educativos modernos -altamente burocráticos e impersonales-, pasada la segunda mitad del siglo XX se vieron obsoletos frente a las demandas de una sociedad cambiante a nivel mundial, no solo respecto de los paradigmas de la modernidad basados en la idea de la razón y el progreso -las Guerras Mundiales, el ferviente racismo y el consecuente exterminio de una porción de la humanidad pusieron fin a ese optimismo-, sino también respecto de las formas de comunicación, el alcance de las mismas, la influencia de la tecnología y el manejo de la información.

La sociedad, más preocupada por disfrutar un presente y construir un futuro que por idealizar un pasado, desconfía respecto de las generaciones previas -desconfianza basada en que se trató de generaciones conflictivas, intolerantes y beligerantes, responsables, entre otras cosas, de acontecimientos catastróficos como el holocausto. Siguiendo a Arendt, estas generaciones anteriores no serían capaces de brindar respuestas afines a las nuevas demandas; la autoridad que tradicionalmente descansó en el rol del adulto lógicamente se vio atravesada por este cambio de paradigma común a las generaciones posteriores a la Segunda Guerra Mundial. Sería muy difícil, a partir de la segunda mitad del siglo XX, confiar en el rol del adulto -y por añadidura en el rol del maestro- como aquel portavoz de un pasado donde podría hallarse la sabiduría necesaria para afrontar los conflictos presentes y futuros.

En esta línea de pensamiento, se puede decir que la acción educativa siempre conlleva una crisis vinculada a la caducidad constante de sus contenidos. Esta situación es inherente a la función de la educación en la sociedad moderna. Aun cuando se trabaje arduamente en restablecer sus principios, es esperable que acontezca una nueva crisis en el 
momento en que se lleva a cabo cualquier intento de actualización. Esta reiteración permanente de incompatibilidades generacionales se hace evidente en el rol del educador, ya que éste se encuentra atravesado por las tradiciones en las que fue formado y por las novedades de un mundo que se actualiza vertiginosamente. Así,

El problema de la educación en el mundo moderno se centra en el hecho de que, por su propia naturaleza, no puede renunciar a la autoridad ni a la tradición, y aun así debe desarrollarse en un mundo que ya no se estructura gracias a la autoridad ni se mantiene unido gracias a la tradición (Arendt 1996: 207).

La búsqueda permanente de un equilibrio y la inmediata caducidad de éste provocan una irremediable crisis inherente a los principios fundamentales de la educación. Esta crisis se basa en que los pilares fundamentales del conservadurismo, apoyados en la autoridad, pierden vigencia con una velocidad sin precedentes. El mundo que ahora avanza hacia la novedad permanente y la exaltación de lo efímero distorsiona el rol del adulto y el ejercicio de autoridad que históricamente se le adjudicó, cuando "la camaradería y la autoridad (...) eran las dos caras de una misma moneda, y la autoridad del maestro tenía una base firme en la omnipresente autoridad del pasado como tal" (Arendt 1996: 206).

En la actualidad, el vacío de autoridad no solo está vinculado al rol del maestro, sino también al de la institución escolar como lugar de transmisión de saberes y como espacio educativo por excelencia. Ya no es una novedad pensar la educación como instrumento de los Estados modernos, como estrategia alternativa a la violencia para ejercer el control sobre gran parte de la población. Sin embargo, esa función de la educación como sistema de coerción sin el uso de la fuerza, ya no brinda respuestas para afrontar los desafíos del mundo que habitamos.

\subsection{Apuntes sobre la autoridad y su relación con la educación}

Si bien el tema de la autoridad no es central en el desarrollo del presente trabajo, resulta pertinente en su vinculación con la educación, particularmente si queremos comprender la situación de crisis que la atraviesa. La crisis de la educación no está aislada ni es exclusiva, está en relación directa con una crisis general que afecta a la sociedad occidental desde la segunda mitad del siglo XX. El desequilibrio y la confusión que distorsionan la noción de 
autoridad -evidenciada en los usos corrientes del término-, dan cuenta de este cambio en los valores tradicionales que afecta a la sociedad en general. ${ }^{7}$

Para entender a qué nos referimos con autoridad y analizar aquellos aspectos que definirían su situación de crisis, es preciso determinar algunas consideraciones. En este análisis nos servirá de referencia el tercer capítulo del libro Entre el pasado y el futuro, dedicado a la reflexión y a la revisión histórica de la noción de autoridad desde sus orígenes grecorromanos. En dicho libro, Arendt afirma que "la autoridad se ha esfumado del mundo moderno, (...) la propia palabra está ensombrecida por la controversia y la confusión" (Arendt 1996: 101). Reafirmando lo mencionado anteriormente, las causas de este malentendido acerca de la noción de autoridad se hallarían en estrecha relación con una crisis más honda que abarcaría al mundo moderno y sus pilares fundamentales. ${ }^{8}$ Hecha esta aclaración, comenzaremos por definir qué entiende Arendt por autoridad, para luego profundizar sobre su estado de crisis.

Cuando la autora hace referencia a la autoridad, destaca a este término como uno de los más confusos entre los asuntos humanos. Es frecuente observar, tanto en el ámbito de la política como en la esfera de los asuntos humanos, una confusión comúnmente asociada a los conceptos de poder y violencia; esta confusión está en relación con los mecanismos elegidos por los diversos sistemas políticos y el ejercicio del poder. Al distinguir la autoridad de otros términos, Arendt la define del siguiente modo:

$\mathrm{Su}$ característica es el indiscutible reconocimiento por aquellos a quienes se les pide obedecer; no precisa ni de la coacción ni de la persuasión. [...] El mayor enemigo de la autoridad es, por eso, el desprecio y el más seguro medio de minarla es la risa (Arendt 2006: 62).

\footnotetext{
${ }^{7} \mathrm{Si}$ bien podría fácilmente interpretarse que gran parte de la obra de Arendt, y particularmente la compilación de ensayos titulada Entre el pasado y el futuro, hace referencia a la sociedad norteamericana de mediados del siglo XX, esto sería un reduccionismo respecto del alcance de la teoría de la filósofa en cuestión. En el libro citado anteriormente, Arendt lleva a cabo un minucioso análisis histórico-político respecto de los valores de la modernidad, los cuales se hallarían en un estado de crisis evidenciado por los cambios en los valores que guiaron la política de occidente. La autoridad, la libertad, la historia, la educación, la perspectiva de futuro, entre otros, son los temas que dan cuenta de este cambio en los pilares de la sociedad occidental; y estos cambios no afectan exclusivamente a la sociedad norteamericana -las guerras que atravesaron el siglo XX y sus consecuencias a nivel mundial dan cuenta de ello.

${ }^{8}$ En esta línea de análisis, pero centrándose en las revueltas políticas de la segunda mitad del siglo XX, también es posible hallar una descripción detallada respecto de la noción de autoridad en el libro de Arendt Sobre la violencia. Allí se diferencia del análisis histórico desarrollado en Entre el pasado y el futuro (acompañando la diferenciación de las nociones poder y violencia).
} 
Un ejemplo vinculado a esta concepción puede hallarse en la relación entre padre e hijo: allí el vínculo no supone una dominación por medio de la coacción, pero sí es requerido un reconocimiento de los roles culturalmente legitimados en ambas partes. Cuando el hijo desobedece alguna norma impuesta por su progenitor, espera al menos un reto, un castigo y de esa manera la restauración de la norma violada. De esta manera, padre e hijo cumplen roles basados en la autoridad que le corresponde asumir a cada uno; claro que las características que acompañan al ejercicio de estos roles pueden variar de una sociedad a otra o incluso de una familia a otra.

Otro ejemplo puede observarse en la relación entre un enseñante y sus aprendices. Quien pretende ejercer la enseñanza, en el marco de una escuela, solo puede intentarlo si los alumnos creen y aceptan el lugar del profesor como portador de un saber que jerárquicamente lo posiciona por encima de sus alumnos. Cuando esto no sucede, cuando los alumnos creen que un profesor no domina un saber ni los requisitos pedagógicos para transmitirlo, la autoridad del enseñante se diluye a causa del descreimiento y la desconfianza. Arendt destaca que no solo el rol del maestro se encuentra en crisis, sino que el rol del adulto en general también se halla atravesado por esta situación. Esta es una de las causas que amplía el efecto de la crisis de la autoridad, y consecuentemente se traslada al campo de la educación, afectando el lugar del maestro como voz calificada en la tarea de enseñar. Cabe destacar que la filósofa no pensaba en una crisis localizada, ni en los problemas de algunas escuelas en particular: más bien, la crisis se encontraría asociada a una constante y creciente obsolescencia de los sistemas educativos y, como se mencionó anteriormente, a cambios vertiginosos en la noción de autoridad. Esta crisis de la autoridad en la sociedad moderna, a su vez, se advierte en el rol del adulto y en el lugar privilegiado que ocupa el niño:

La autoridad que dice a cada niño que tiene que hacer y que no tiene que hacer está dentro del propio grupo infantil y, entre otras consecuencias, esto produce una situación en la que el adulto, como individuo, está inerme ante el niño y no establece contacto con él. Sólo le puede decir que haga lo que quiera y después evitar que ocurra lo peor. Así es como se rompen las relaciones reales y normales entre niños y adultos (Arendt 1996: 192-193).

Desde comienzos del siglo XX nadie sabe bien qué es la autoridad, qué función cumple en el campo político y por qué es necesaria para la convivencia humana. La autoridad, afirma Arendt, brindó al mundo la permanencia y la estabilidad que los humanos necesitan justamente porque son seres mortales (Arendt 1996: 105); sin embargo, desde que 
se perdió el fundamento romano que originalmente acompañaba el significado de dicho término, el concepto de autoridad puede ser fácilmente convertido en cualquier otra cosa. ${ }^{9}$ Esta idea romana de autoridad (cuyo significado se perdió a lo largo de la historia de occidente debido al uso que los diversos intereses político-religiosos hicieron del término), se encuentra en estrecha relación con las nociones de religiosidad y de tradición. Este significado puede rastrearse desde la filosofía política griega y su posterior acepción romana, específicamente en el valor que le asignaban a las leyes como mediador fundamental para el gobierno de la polis. La autoridad implicaba entonces una obediencia en la que los hombres conservan su libertad, y Platón esperaba haber hallado tal obediencia cuando, en su vejez, confirió a las leyes la cualidad que las convierte en gobernantes indiscutibles de todo el campo público (Arendt 1996: 116). ${ }^{10}$ Esta búsqueda de los griegos por conseguir instrumentos de gobierno más eficientes y estables que la persuasión, pero sin recurrir al uso de medios extremos como la violencia, dieron como resultado la creación de las leyes y de la autoridad, interpretada como sustento necesario para que dichas leyes cuenten con la legitimación requerida para su aplicación. En pocas palabras, la autoridad fue pensada originalmente por los griegos y posteriormente por los romanos como el marco legitimador necesario para asegurar el funcionamiento de las leyes.

El valor de la autoridad fundada por los griegos para el control de las sociedades halló su réplica inmediata en manos de la Iglesia Católica, que vio en el uso de la autoridad un recurso fundamental para llevar a cabo el control por medio del poder ligado al valor de las creencias (los fundamentos bíblicos de la religión cristiana suplantaron las leyes griegas manteniendo el uso de la autoridad como herramienta fundamental para legitimar el gobierno del clérigo). En términos de Arendt:

\footnotetext{
${ }^{9}$ La crisis respecto de la noción de autoridad responde, a su vez, a una crisis aún más amplia en relación al sentido y la utilización de las palabras. Arendt aclara al respecto: "ya no vivimos en un mundo común en el que las palabras de todos poseen una significación incuestionable de modo que, además de estar condenados a vivir verbalmente en un universo por completo carente de sentido, nos garantizamos unos a otros el derecho de retirarnos a nuestros propios mundos de significación" (Arendt 1996: 105).

${ }^{10}$ Arendt recurre frecuentemente a la obra de Platón para desarrollar el significado político de la autoridad como medio alternativo y a la vez pacífico, superador de la persuasión en la esfera de los asuntos públicos. En sus palabras, "Platón empezó a considerar que la persuasión era insuficiente para guiar a los hombres y para buscar algo que los comprometiera sin necesidad de usar medios exteriores de violencia (...). En Las leyes, Platón propone, a modo de sustituto de la persuasión, introducir las leyes en las que se explique a los ciudadanos su intención y objetivo" (Arendt 1996: 118).
} 
Gracias a que la fundación de la ciudad de Roma se repitió en la fundación de la Iglesia Católica -aunque, por supuesto, con un contenido radicalmente distinto-, la era cristiana se apoderó de aquella trinidad romana de religión, autoridad y tradición (Arendt 1996: 138).

El devenir histórico-político de la modernidad -a pesar de fundamentar sus Estados en el requerimiento de la autoridad para asegurar el funcionamiento de sus leyes y la creencia en sus representantes- reescribió el valor y el significado de la autoridad, con más énfasis en el campo de la política. La influencia de la autoridad en el espacio político se prestó a diversas confusiones y abusos respecto de sus cualidades como recurso para la legitimación del dominio. De esas confusiones asociadas a los manejos políticos del término, Arendt destaca la confusión entre autoridad y violencia como una de las más preocupantes, puesto que el significado original del término intentaba alejarse de los instrumentos de la violencia. La autora explica esta confusión de la siguiente manera:

La autoridad siempre demanda obediencia y por este motivo es corriente que se la confunda con cierta forma de poder o violencia. No obstante, excluye el uso de medios externos de coacción: se usa la fuerza cuando la autoridad fracasa. Por otra parte, autoridad y persuasión son incompatibles, porque la segunda presupone igualdad y opera a través de un proceso de argumentación. [...] Ante el orden igualitario de la persuasión se alza el orden autoritario, que es siempre jerárquico (Arendt 1996: 102).

En esta línea, Arendt propone también diferenciar los modelos de gobierno autoritarios de otras formas de organización política como los totalitarismos o la tiranía; si bien el rasgo que poseen en común estas modalidades de gobierno se basa en la limitación de las libertades individuales, cada una lo hace de diversas formas, y esta confusión no haría otra cosa más que sumar desconciertos al concepto de autoridad. Mientras que el autoritarismo se basa en la confianza depositada en las leyes y en el funcionamiento de un código que se encuentra por encima de los hombres, la tiranía requiere de una figura única, la cual media en todas las decisiones asumiendo la inferioridad de sus gobernados -entre los gobernados no hay diferencias, la igualdad está basada en la inferioridad respecto del tirano que los gobierna. El tirano es el señor que gobierna como uno contra todos, y aquellos a los que oprime son todos iguales, es decir, todos carecen de poder (Arendt 1996: 109). A diferencia de esta equidad generada en la falta de poder, el autoritarismo, en su estructura jerárquica, es la menos igualitaria de todas las formas: incorpora la desigualdad y la distinción como principios omnipresentes. 
La organización totalitaria de un gobierno supone la desaparición de las autoridades tradicionalmente reconocidas; aquí las decisiones políticas pasan por una figura central y su círculo más cercano, que defiende la ideología y las decisiones de su líder. Éste, teniendo en cuenta las experiencias políticas del siglo XX, se presenta a sí mismo como una figura carismática y heroica; si bien mantiene la apariencia física del hombre corriente, su supuesta naturaleza superior justificaría la trascendencia de sus actos (inventados y exacerbados a través de recursos como la propaganda y el control de los medios de comunicación), los cuales ameritarían la entrega y devoción absoluta por parte de las masas. Arendt propone entender el totalitarismo como una estructura de capas concéntricas que colaboran en la resistencia respecto de la influencia del mundo real. Di Pego afirma que esta organización política constituye la mayor advertencia respecto de las posibilidades de recrear sobre las bases completamente nuevas los asuntos humanos, erradicando completamente la acción y volviendo irreconocibles a los seres humanos (Di Pego, A. 2015: 256). En referencia a este absoluto irreal que caracteriza al totalitarismo, Arendt sostiene:

A diferencia de los regímenes tiránicos y autoritarios y por contraste con ellos, me parece que la imagen adecuada del gobierno y la organización totalitarios es la estructura en capas concéntricas, o de cebolla, en cuyo centro, en algo así como un espacio vacío, está el jefe; haga lo que haga este conductor -ya integre los poderes políticos, como en la jerarquía autoritaria, o bien oprima a los gobernados, como un tirano-, lo hace desde dentro y no desde fuera ni desde arriba (Arendt 1996: 109).

Poniendo la mirada nuevamente en la confusión, a mi entender todavía vigente en occidente, respecto de los significados de autoridad y violencia, ${ }^{11}$ es importante resaltar los intereses políticos conservadores respecto al uso de la violencia como recurso de imposición o restauración de la autoridad -lo que resuena en el argumento, varias veces escuchado, sobre la legitimidad de las dictaduras latinoamericanas de fines del siglo XX. En la última Dictadura Militar Argentina, el discurso que pretendía restaurar la autoridad de las instituciones y de los gobernantes sirvió para legitimar la imposición de un régimen

\footnotetext{
${ }^{11}$ En Entre el pasado y el futuro, Arendt incluye el poder (además de la violencia) como un concepto con el que también suele confundirse el significado de la autoridad. Según la autora, el sentido original del término autoridad proviene del sustantivo auctoritas, que deriva del verbo augere, aumentar, y lo que la autoridad o los que tienen autoridad aumentan constantemente es la fundación. "Los provistos de autoridad eran los ancianos, el Senado o los patres, que la habían obtenido por su ascendencia y por transmisión (...) de los antepasados, a quienes por eso los romanos llamaban maiores" (Arendt 1996: 133). Mientras que el poder encuentra su significado en el consenso, la autoridad halla el suyo en el pasado y en el respeto de la norma, de la ley o del código que se impone sobre los hombres, más allá de su decisión individual o conjunta.
} 
dictatorial, amparado en una maquinaria basada en el uso de la violencia y el terror. Estos elementos de coacción estuvieron acompañados por la aplicación de torturas sistemáticas, llevadas a cabo en diversos centros clandestinos de detención. Los objetivos de la dictadura se centraban en la "reorganización" del supuesto caos político que caracterizaba a Argentina hacia mediados de la década de 1970. Bajo el discurso que pretendía restablecer la autoridad supuestamente perdida a causa de las revueltas políticas entre militantes de izquierda, guerrilleros y tradicionalistas, se creó el vacío político ideal para que los líderes militares (con apoyo internacional de los Estados Unidos, e interno de las clases económicamente dominantes) asuman el liderazgo del país, ocupando por la fuerza todos los ministerios.

Al pretender confundir intencionadamente la violencia con el valor de la autoridad en la organización política de los Estados modernos, nos encontramos ante una confusión cuyas consecuencias - rastreables en la política argentina de los '70-abren las puertas a una peligrosa legitimación de la violencia. Esta reinterpretación políticamente deliberada respecto del significado tradicional de la autoridad (originalmente interpretada bajo la tríada romana de religión, autoridad y tradición) es una peligrosa consecuencia que se basa en la confusión, vigente en la modernidad, entre autoridad y violencia. Cito en extenso un fragmento de Entre el pasado y el futuro que pretende aclarar esta confusión entre ambos términos:

Si la violencia cumple la misma función que la autoridad -es decir, hacer que la gente obedezca-, la violencia es autoridad. Una vez más, nos encontramos con los que aconsejan una vuelta a la autoridad porque piensan que sólo si se vuelve a introducir la relación ordenobediencia se pueden solucionar los problemas de una sociedad de masas. [...] Todos los que confunden el totalitarismo con una estructura autoritaria, implícitamente igualan violencia y autoridad [...]. El punto medular del argumento es siempre el mismo: todo está relacionado con un contexto funcional y el uso de la violencia se toma para demostrar que ninguna sociedad puede existir si no es dentro de un marco autoritario (Arendt 1996: 113).

Al trasladar el problema de la autoridad al campo prepolítico de la educación, ${ }^{12}$ podemos observar que la confusión se agrava desde el punto de vista de los agentes involucrados, puesto que sin autoridad la institución educativa no tiene sentido alguno. Esta falta de sentido se advierte en el malestar de los maestros que allí trabajan, cuando no cuentan con

\footnotetext{
12 Arendt explica en detalle este lugar prepolítico de la educación en su ensayo Reflections on Little Rock: "para el niño, la escuela es el primer lugar fuera de casa, donde establece contacto con el mundo público que rodea a él y su familia. Este mundo público no es político sino social, y la escuela es para el niño lo que un trabajo es para un adulto" (Arendt 1959: 53).
} 
el respeto y la creencia necesarios para ejercer sus tareas. Esto lleva a que los maestros no posean una voz autorizada para pararse frente a sus alumnos con el reconocimiento que originalmente se asoció a sus funciones. De esta manera, la crisis de la autoridad se hace visible en el campo de la educación moderna, ${ }^{13}$ dejando a los maestros sin respaldo y a los alumnos sin referente, librándolos a la suerte y a los riesgos de su propio gobierno.

En un ensayo de Arendt publicado en el año 1959, titulado Reflections on Little Rock, puede rastrearse una preocupación que vincula cuestiones relativas a la autoridad con el campo de la educación. El ensayo retoma un episodio ocurrido en Little Rock, Arkansas, cuando un grupo de nueve afroamericanos fueron expulsados e impedidos de iniciar las clases en una escuela secundaria. ${ }^{14}$ Este acontecimiento coronaba una serie de disputas que estaban teniendo lugar hacia el interior de los Estados Unidos respecto de la educación dirigida a los blancos y a los negros -en relación con el problema aún mayor de la segregación y la discriminación que atravesó la sociedad norteamericana desde su fundación hasta la actualidad. A partir de estos hechos, Arendt desarrolló una serie de ideas asociadas a la educación, la autoridad y la política, a partir de una lectura minuciosa de los acontecimientos. Con una fuerte, pero justificada crítica hacia las autoridades civiles (encarnadas fundamentalmente por el gobernador racista Orval Faubus) y militares, que permitieron el acercamiento físico de las masas opositoras al ingreso de los estudiantes, la filósofa en cuestión resaltó la gravedad del problema de la ausencia de una autoridad en la resolución del conflicto. ${ }^{15}$ En sus propios términos:

\footnotetext{
${ }^{13}$ Sumado a esta crisis de la sociedad moderna respecto de la concepción de la autoridad, de su influencia en el campo de la educación y del frágil significado de las palabras, resulta pertinente tomar el ejemplo del problema de la autoridad en la educación Argentina contemporánea. Silvia Bleichmar, en una conferencia brindada en 2006 por el Observatorio Argentino de Violencia en las Escuelas, explica en detalle cómo interviene esta confusión en el escenario educativo actual: "La cuestión de la asimetría nos preocupa no solamente en relación con los jóvenes, se está planteando como preocupación en todos los modelos. Cómo no ejercer el autoritarismo y al mismo tiempo no generar una simetría en la cual quienes tienen que ser responsables no se hacen responsables, como si hubiera un temor de que al ejercer la asimetría se ejercieran modelos autoritarios, cuando la asimetría lo que implica son formas de responsabilidad y no formas de autoridad. (...) En la Argentina, a partir de los modos en los que se ejerció el poder despótico durante muchos años, hay una cierta desvalorización de la asimetría" (Bleichmar 2008: 143-144).

${ }^{14}$ Los afroamericanos originalmente expulsados pudieron asistir a clases a partir de la intervención del presidente Eisenhower, quién envió tropas del ejército de Estados Unidos a Little Rock para garantizar la permanencia y seguridad dentro de las instalaciones de la escuela. El hecho tuvo alcance mediático a nivel mundial, y se convirtió en una de las causas más repudiadas por los impulsores de los derechos civiles igualitarios. Fuente: http://web.archive.org/web/20081018122555/ http://www.america.gov/st/washfilespanish/2007/March/20070327110756liameruoy0.9536096.html

${ }^{15}$ El ensayo mencionado no solo sirve para analizar cuestiones relativas a la educación, la autoridad y la discriminación, también resulta un instrumento de referencia a la hora de entender la diferencia entre lo
} 
Los acontecimientos en Little Rock fueron suficientemente esclarecedores y aquellos que deseaban culpar de los disturbios únicamente a la extraordinaria mala conducta del gobernador Faubus pueden estar seguros al considerar el silencio elocuente de los senadores liberales de Arkansas. El lamentable hecho era que los ciudadanos respetuosos de la ley de la ciudad dejaron las calles a la turba, tal que ni los ciudadanos blancos ni los negros sentían que era su deber ver los niños negros seguros en la escuela (Arendt 1959: 48). ${ }^{16}$

Arendt destaca la importancia de resolver este tipo de disputas a través de un juicio legitimado en la noción de la autoridad. Para el caso de Little Rock, la gravedad de los hechos ameritaba un ejercicio de la autoridad dedicado a evitar una intervención violenta, tanto por parte de los manifestantes (entre los que estaban incluidos algunos estudiantes blancos), como de la comunidad afroamericana. En la medida en que los padres y maestros le fallan como autoridades, el niño va a conformar con más fuerza su propio grupo, y bajo estas condiciones, las de los pares, el grupo se convertirá en su autoridad suprema. El resultado sólo puede ser un aumento de la turba y la regla de pandillas (Arendt 1959: 48). Librar a los jóvenes afroamericanos a su suerte, los expuso indefensos ante los insultos, escupidas y amenazas de linchamiento (situación evidenciada en una foto que recorrió el mundo a través de los periódicos). ${ }^{17}$ Para Arendt, esta es una oportunidad de reflexionar sobre lo que sucede cuando se deja la autoridad en manos de la "ley de la calle", y advertir sobre los riesgos de entregar el poder a las masas carentes de reflexión. Al respecto, Arendt sostiene:

Incluso antes de la llegada de las tropas federales, los ciudadanos sureños respetuosos de la ley habían decidido que la aplicación de la ley contra la ley de la turba no era de su

político y lo social. En términos de Di Pego: "la relación entre lo social y lo político recrea en parte el conflicto entre diferencia e igualdad. Arendt no tiene duda de que todos los ciudadanos deben ser reconocidos como iguales ante la ley, pero se muestra renuente a promover que esta igualdad formal se materialice en la sociedad aboliendo todo tipo de diferenciación. Y esta renuencia no era infundada sino que se basaba en la proliferación del conformismo y en la disolución de las posibilidades de diferenciación que el Estado de bienestar y el auge correlativo de la sociedad de masas parecían llevar consigo" (Di Pego 2005: 27). Si bien Arendt promueve la diferenciación -requisito vinculado a la noción de pluralidad y a una forma de hacer frente a la sociedad de masas-, el problema radica cuando la misma es introducida a la fuerza en la esfera de lo político y privado. En definitiva, Arendt se muestra crítica tanto respecto de la intromisión de lo político en el reino de lo social, como de la intromisión de la lógica de la diferenciación en el espacio político y privado. (Di Pego op. cit.).

${ }^{16}$ Versión traducida por María Cristina Daponte.

${ }^{17}$ Me parece interesante, a los efectos de completar el recorrido de las reflexiones de Arendt sobre Little Rock, citar los comentarios de la autora en relación a la fotografía que expone las agresiones de los blancos sobre el grupo de estudiantes negros: "La imagen me parecía como una fantástica caricatura de educación que, al abolir la autoridad de los adultos, niega implícitamente su responsabilidad en el mundo que han llevado a sus hijos y se niega el deber de guiarlos en ella ¿hemos llegado ahora hasta el punto en que son a los niños a los que se les pide cambiar o mejorar el mundo? ¿Intentamos que nuestras batallas políticas sean peleadas sólo en los patios de las escuelas?" (Arendt 1959: 49). Fuente de la fotografía: http://www.hannaharendtcenter.org/?tag=reflections-on-little-rock 
incumbencia. En otras palabras, la llegada de tropas hizo poco más que cambiar la resistencia de pasiva en masiva (Arendt 1959: 49).

\subsection{Conclusiones del apartado}

Cuando los discursos tradicionalistas pretenden hallar soluciones a partir de un regreso espontáneo a la salvación de la autoridad, no solo se corre el riesgo de repetir sistemáticamente los errores del pasado en cuanto a la implementación de políticas extremistas y a la legitimación de la violencia, también nos encontramos en presencia de una interpretación de la educación reducida al mundo irreflexivo de la labor y el trabajo. Este reduccionismo que confina la educación al hacer, es decir, a una fábrica de alumnos en el sentido arendtiano del término, como si su utilidad se agotara tan solo en la coacción sin el uso de la fuerza, nos invita a reflexionar respecto del interés de los Estados modernos en sostener los sistemas educativos tradicionales. Esta resistencia a su desaparición, queda explicitada en una grotesca obsolescencia hacia el interior de su funcionamiento, evidenciado en la permanencia de absurdas burocracias y en el derrumbe literal de sus paredes.

Si bien Arendt no centró su análisis en el diseño de propuestas educativas, sus reflexiones en cuanto a las contradicciones que el concepto de educación moderna arrastra en su recorrido por las sociedades occidentales nos sirve como punto de partida para realizar algunos ensayos en este sentido. Un ejercicio en esta línea de análisis sería pensar en la educación asociada a los conceptos de cuerpo y acción, ya no enmarcados por la naturalización de las limitaciones a través de la homogeneización y la estandarización, sino a partir de la exploración motivada por la infinita potencialidad del ser humano; intentando abordar la palabra y el acto sin mediaciones tan marcadamente intencionadas como las desarrolladas por los Estados modernos. Si bien toda propuesta educativa conlleva una intencionalidad política y un recorte de saberes, la exploración del cuerpo en relación a la acción, esto es, las actividades del hombre en libertad y la exploración de sus potencialidades, conforman un campo que hasta el momento se agota únicamente en unos pocos ensayos académicos. 


\section{Capítulo 4. El cuerpo como instrumento y objetivo de la violencia}

Nada, en mi opinión, podría ser teóricamente más peligroso que la tradición de pensamiento orgánico en cuestiones políticas, por la que el poder y la violencia son interpretados en términos biológicos.

(Arendt, H., Sobre la violencia)

\section{1 ¿Por qué la violencia es un problema de investigación?}

Para entender el fuerte vínculo presente en los escritos de Arendt sobre temas vinculados la violencia, las formas totalitarias o los abusos de autoridad, resulta clave atender la noción de autor propuesta por Foucault. Este filósofo e historiador francés, crítico de las Ciencias Sociales contemporáneas, propone acentuar la mirada sobre las condiciones de posibilidad del surgimiento de una obra, ya que esta encontraría su existencia alejada de la propiedad individual. En este sentido, la obra es exterior y anterior al escritor como figura individual; un escrito precede y trasciende a quien lo escribe, pertenece a un momento histórico determinado, donde halla el sentido de su existencia. En términos de Foucault:

Se dice, en efecto, que lo propio de la crítica no es poner de relieve las relaciones de la obra con el autor, ni querer reconstruir a través de los textos un pensamiento o una experiencia; más bien tiene que analizar la obra en su estructura, en su arquitectura, en su forma intrínseca y en el juego de sus relaciones internas (Foucault 2010: 56).

Al considerar que la obra trasciende a quien escribe, no sería ilógico pensar que el contexto conflictivo de la Segunda Guerra Mundial y la privación de derechos a la que Arendt fue sometida, ${ }^{1}$ dieron como resultado un vínculo fundamental entre sus escritos y temas vinculados a la violencia, la política y el totalitarismo. La misma filósofa descree de la idea de autor como dueño exclusivo de una obra; en cambio, propone centrar la mirada en los efectos de la acción y el discurso sobre las vidas de los mortales, y en la imposibilidad de intervenir sobre la propia vida excluyendo el contexto histórico y político. El siguiente pasaje extraído de La Condición Humana da cuenta de lo mencionado:

\footnotetext{
1 Esta privación de derechos hace referencia de manera general a los abusos de poder por parte del Nacionalsocialismo en Alemania entre los años 1933 y 1945; y de modo particular, al encarcelamiento de Arendt, su detención en un campo de concentración, su condición de apátrida y su necesidad de huir hacia Norteamérica como exiliada política en el año 1941. Al respecto, en una entrevista llevada a cabo para la televisión alemana en 1964 Arendt expresó lo siguiente: "Eso nunca debió haber ocurrido, y no me refiero con esto al número de víctimas; me refiero a la fabricación de cadáveres. (...) Ahí pasó algo de lo que ya nadie puede desprenderse".Entrevista realizada a Hannah Arendt por Günter Gauss y emitida por la televisión de Alemania Occidental el 28 de Octubre de 1964. Véase al respecto Arendt (2005).
} 
Aunque todo el mundo comienza su vida insertándose en el mundo humano mediante la acción y el discurso, nadie es autor o productor de la historia de su propia vida. Dicho con otras palabras, las historias, resultados de la acción y el discurso, revelan un agente, pero este agente no es autor o productor. Alguien la comenzó y es su protagonista en el doble sentido de la palabra, o sea, su actor y paciente, pero nadie es su autor (Arendt 2014: 208).

En el caso particular de la autora en cuestión, sería imposible negar la influencia del contexto social de la Europa de posguerra en relación al contenido de sus escritos. Entre los temas más recurrentes de Arendt, y ampliando lo mencionado anteriormente, es posible rastrear contribuciones en el campo de la política, el poder, el totalitarismo, las guerras del siglo XX, el humanismo, la educación y el análisis de la violencia como acontecimiento social.

Para Arendt, la problematización acerca de la violencia en occidente no recibió la atención merecida. Esta profundización teórica insuficiente daría cuenta de una negación, supuestamente vinculada a la connotación negativa del término, que explicaría los mitos y supuestos tejidos alrededor del mismo. En sus propias palabras:

Nadie consagrado a pensar sobre la historia y la política puede permanecer ignorante del enorme papel que la violencia ha desempeñado siempre en los asuntos humanos, y a primera vista resulta más que sorprendente que la violencia haya sido singularizada tan escasas veces para su especial consideración [...]. Esto demuestra hasta qué punto han sido presupuestas y luego olvidadas la violencia y su arbitrariedad; nadie pone en tela de juicio ni examina lo que resulta completamente obvio (Arendt 2006: 16).

El abordaje de la violencia como problema de investigación sirve como herramienta metodológica para numerosas disciplinas sociales. Pensar la interpretación que la autora lleva a cabo respecto de la violencia como problemática social resulta de particular interés en campos como la historia, sociología, la filosofía y la educación; no solo por compartir un vínculo directo con la política, sino también porque la violencia, analizada como tema principal o secundario, es un tema recurrente entre las preocupaciones de las sociedades occidentales modernas.

\subsection{Una necesaria revisión del pasado}

Arendt centra su análisis en la modernidad y en los acontecimientos políticos que dieron lugar y trascendieron a la Segunda Guerra Mundial. Sus aportes nos sirven a modo de herramientas para interpretar cómo llegamos a nuestro presente, de qué manera la modernidad ha devenido en los acontecimientos que conocemos y que perspectivas de 
futuro podemos prever. Esta es la propuesta metodológica que atraviesa gran parte de la obra de Arendt, explicitada con detalle en el prólogo de su libro Entre el pasado y el futuro:

El hombre siempre vive en el intervalo entre pasado y futuro, el tiempo no es un continuo, un flujo de sucesión ininterrumpida, porque está partido por la mitad, en el punto donde él se yergue; y su punto de mira no es el presente, tal como habitualmente lo entendemos, sino más bien una brecha en el tiempo al que su lucha constante, su definición de una postura frente al pasado y al futuro otorga existencia (Arendt 1996: 17).

Arendt retoma la propuesta de Kafka respecto de ubicar a "él" en medio de una batalla librada por las fuerzas del pasado y el futuro. ${ }^{2}$ El escenario es un campo de combate sobre el que las fuerzas del pasado y el futuro chocan una con otra; entre ellas podemos encontrar al hombre que Kafka llama "él”, quien, si quiere mantenerse firme por completo, debe presentar batalla a ambas fuerzas (Arendt 1996: 16). El ejercicio reflexivo que propone Arendt supone una revisión crítica del pasado; esto abre la posibilidad de generar una brecha en nuestro presente, es decir, entender dónde estamos y lo que hacemos a partir de un análisis, tanto de la tradición como de las perspectivas respecto del futuro. Se abre entonces una brecha entre el pasado y el futuro, puesto que cuestionamos el legado del pasado, que ya no se nos presenta en continuidad con el presente (Di Pego 2015: 219). El tiempo en la perspectiva de Arendt no es algo lineal y predecible; está sujeto a los posicionamientos políticos de los actores que pretenden hacer tanto una interpretación histórica como una proyección del futuro. Este posicionamiento debe conllevar ciertas precauciones teóricas para no caer en interpretaciones apresuradas y carentes de fundamento; respecto del pasado, la propuesta de Arendt es no desprestigiar lo anterior, es decir, no acusar apresuradamente al pasado de obsoleto por su carácter "tradicional". Respecto del futuro, la precaución debe estar ligada a no dejarse llevar por el terreno de las utopías, ya que la utopía, por su carácter relativo, socava las posibilidades concretas de proyección. La ejercitación de un pensamiento político debe situarse en el vértice atemporal de la reflexión y la propia experiencia vivida. En términos de Arendt: "el propio pensamiento surge de los incidentes de la experiencia viva y debe seguir unido a ellos a modo de letrero indicador exclusivo que determina el rumbo" (Arendt 1996: 20).

\footnotetext{
${ }^{2}$ Desde mi punto de vista, Arendt resalta la utilización por parte de Kafka del pronombre personal "él”, en vez de "alguien" para referirse al hombre de manera genérica. La siguiente cita de Arendt da cuenta de esta mención: “(...) el hombre, dentro de la realidad total de su ser concreto, vive en esa brecha del tiempo situada entre el pasado y el futuro. Sospecho que la brecha no es un fenómeno moderno, que quizá ni siquiera es un dato histórico, sino algo coetáneo de la existencia del hombre sobre la tierra" (Arendt 1996: 19).
} 
La preocupación de Arendt en relación a la revisión del pasado se centra en la mirada que se tiene en el presente respecto de dicho pasado, y en los mecanismos en que el trabajo de la historización se lleva a cabo. Toda lectura respecto de acontecimientos previos estará mediada por los incidentes políticos que influyen en el presente; mirar el pasado desde el presente es hacerlo con un velo de significados que ponen en juego diversos intereses políticos (los que justificarían la necesidad de revisar el pasado). La tarea de un historiador, similar a la de un pescador de perlas, ${ }^{3}$ radicaría en recuperar aquellos acontecimientos pasados y sus respectivos significados.

El análisis de los intereses que median en la lectura del pasado pueden fácilmente rastrearse en Los orígenes del totalitarismo, donde Arendt describe detalladamente el uso que los nazis hicieron de la naturaleza y de la historia (y particularmente de las teorías darwinianas) $)^{4}$ para legitimar sus actos. A partir de dichas lecturas -mediadas por el interés en la legitimación de una supuesta raza aria superior al resto de la humanidad-, los pensadores y propagandistas del Nazismo crearon una ideología que amoldaba la noción de naturaleza a su conveniencia política. ${ }^{5}$ Esta ideología sirvió al convencimiento de las masas y justificó la aniquilación de millones de personas de diversos orígenes y creencias, convertidas en enemigos políticos. Estos eran considerados indignos de ser incluidos en el amparo de la naturaleza "superior" (a la que sólo pertenecían los alemanes nacionalsocialistas). La lectura de una tradición fundada en los pilares de la ciencia, la

\footnotetext{
${ }^{3}$ Analogía de la tarea del historiador, minuciosamente desarrollada por Di Pego (2015), a partir de la cual Hannah Arendt describe a Walter Benjamin como un investigador que recupera aquellos sentidos "cristalizados" del pasado que permanecieron inmunes al paso del tiempo. En palabras de Di Pego: "La descripción que Arendt realiza de Walter Benjamin como un pescador de perlas que rescata las riquezas que, cristalizadas por el paso del tiempo, se conservan en el lecho marino, también puede resultar esclarecedora respecto de su propio pensamiento, que sin lugar a dudas se forjó en estrecha relación con el legado del propio Benjamin" (Di Pego 2015: 221).

${ }^{4}$ Este interés político en el uso de la historia y la naturaleza, explícitamente llevado a cabo por los nazis, queda expuesto en un pasaje de Los orígenes del totalitarismo del siguiente modo: "Lo que por eso tratan de lograr las ideologías totalitarias no es la transformación del mundo exterior o la transmutación revolucionaria de la sociedad, sino la transformación de la misma naturaleza humana. Los campos de concentración son los laboratorios donde se prueban los cambios en la naturaleza humana, y su ignominia no atañe sólo a sus internados y a aquellos que los dirigen según normas estrictamente «científicas»; es tema que afecta a todos los hombres. Y la cuestión no es el sufrimiento, algo de lo que ya ha habido demasiado en la Tierra, ni el número de sus víctimas. Lo que está en juego es la naturaleza humana como tal” (Arendt 1998: 685).

${ }^{5}$ Este uso explícito de la propaganda para fines políticos, particularmente para el convencimiento de las masas respecto de las intenciones nacionalsocialistas, queda claramente explicado en el siguiente pasaje de Los orígenes del totalitarismo: "La propaganda nazi concentró todas sus perspectivas (...) en un concepto que denominó Valksgemeinschaft. Esta nueva comunidad, ensayada por el movimiento nazi en la atmósfera pretotalitaria, se hallaba basada en la igualdad absoluta de todos los alemanes, una igualdad no de hecho, sino de naturaleza, y en su absoluta diferencia de todos los demás pueblos" (Arendt 1998: 529).
} 
razón y el progreso, en el caso del Nazismo sirvió de fundamento para justificar su ideología extremadamente racista.

Sólo a partir de la metódica tarea de recuperar los sentidos originales en que los hechos del pasado acontecieron, podremos rastrear los fundamentos y significados necesarios para entender nuestro presente. El pensamiento de Arendt se erige y se desarrolla en un vínculo permanente con la actualidad, y desde esta preocupación se remonta al pasado con el objeto de descubrir allí claves para repensar el presente (Di Pego 2015: 220). Sin embargo, Arendt no intenta rastrear el pasado exactamente como sucedió, lo que sería ilógico y metodológicamente imposible; la propuesta de Arendt supone una interpretación crítica vinculada con la verdad como des-ocultamiento. Los conceptos preservan del pasado sentidos que permanecen ocultos, y la interpretación crítica consiste en quitar el velo para que estos puedan emerger (Di Pego 2015: 220). En el caso de temas como la violencia, el ejercicio de una interpretación crítica estaría dirigido a comprender su connotación negativa, su utilidad como medio para la imposición de regímenes políticos, las confusiones que este término conlleva en relación a la noción de poder y las diferencias respecto del concepto de autoridad.

Hablar de violencia siempre conlleva cierta repugnancia, se lo puede considerar uno de los temas más oscuros en las Ciencias Humanas; pero, ¿por qué este concepto arrastra una connotación negativa? ¿Es que acaso asumir la presencia de la violencia supone el fracaso de los recursos "no violentos" legitimados por la mayoría de las sociedades occidentales? ¿Qué tipo de consenso existe detrás del uso de la violencia como mecanismo de coerción? Estos son algunos de los cuestionamientos que se desarrollarán a lo largo del presente apartado, en relación permanente con los escritos de Arendt pertinentes a la temática planteada.

Cabe destacar que los análisis de Arendt respecto de la violencia se vinculan permanentemente con el campo de la política, y con cuestiones vinculadas al poder. Respecto de esta revisión del concepto de violencia en la teoría de Arendt, Hilb aclara: "La violencia en Arendt ocupa un lugar paradójico o, en todo caso, un lugar que no es exactamente el esperado a priori: partiendo de la postura en la cual la violencia es per se ruinosa de la política, donde la violencia es lo opuesto al poder" (Hilb 2001: 11). 


\subsection{Los instrumentos de la violencia}

En un ensayo de Arendt titulado Sobre la violencia, ${ }^{6}$ escrito en 1969, la autora aborda en profundidad acontecimientos políticos relevantes de la segunda mitad del siglo XX, como las revueltas estudiantiles iniciadas en Francia en mayo de 1968, las respuestas represivas frente a estos movimientos y el análisis de algunas réplicas a nivel mundial. Este ensayo resulta clave para entender el concepto de violencia en la teoría de Arendt, puesto que completa el trabajo iniciado en Los orígenes del totalitarismo, donde se analizaba la violencia como medio eficaz y económico llevado a cabo por las políticas totalitarias asociadas al nazismo; y continúa lo desarrollado en La condición humana, donde examinaba la violencia en relación al poder. Hecha esta aclaración respecto de la bibliografía utilizada para el presente apartado, podemos emprender el análisis respecto de los instrumentos que implica la violencia.

La violencia puede prescindir del consenso, de las opiniones, del número, pero depende de los instrumentos, estos son los que garantizan su éxito. En la teoría de Arendt se consideran instrumentos no sólo las clásicas armas que se utilizarían en una guerra; el propio cuerpo, los grilletes de los esclavos, un decreto destinado a la supresión de derechos o la extrema burocratización del Estado también se hallan incluidos en esta lógica. Esta concepción abre considerablemente el abanico de temas a la hora de analizar la violencia como problema social. Tradicionalmente se creía que la violencia era sinónimo de agresión y que sus instrumentos se reducían a ocasionar un daño físico. Sin embargo, con esta concepción sería imposible delimitar con exactitud qué instrumentos están contenidos dentro de la acción violenta; del mismo modo, sería imposible recortar una definición exacta del término violencia, puesto que en la lógica de Arendt el mismo opera inmiscuido

\footnotetext{
${ }^{6}$ El análisis de la violencia en La condición humana está más ligado a la continuación del trabajo iniciado en Los orígenes del totalitarismo, (dónde Arendt analiza las características de los regímenes totalitarios y comunistas de la primera parte del siglo XX). En La condición humana, la violencia aparece como factor mitigador, externo y ajeno a la población de los Estados, dónde el fin último consiste en la coacción de las posibilidades de la acción. En otras palabras, la violencia -y el efecto de terror que su sistematización suscita en las poblaciones subordinadas- es el medio, más frecuentemente utilizado por los regímenes totalitarios, para coartar las libertades de las masas subsumidas bajo el control del Estado. En el libro titulado Sobre la violencia, en cambio, la atención está dirigida al análisis de acontecimientos políticos contemporáneos a la publicación de la primera edición (1969-1970), es decir, que la mirada se centra en las revueltas surgidas a partir del "Mayo Francés" de 1968. A pesar de esta aclaración, es importante destacar que ambas obras son perfectamente compatibles a la hora de llevar a cabo un análisis exhaustivo de la violencia, ya que en ambas se destaca a la violencia como problema inherente a la modernidad; asumiendo que sería imposible reducir el análisis de dicha problemática a un acontecimiento aislado.
} 
entre los más diversos asuntos humanos. Por esta razón, al hablar de violencia en la teoría de Arendt no se hace otra cosa que llevar adelante revisiones históricas y aproximaciones teóricas, sin pretender establecer afirmaciones ortodoxas e indiscutibles.

La autora marca una diferencia entre los términos violencia y acontecimiento violento: mientras que el primero hace referencia a un instrumento de la condición humana para conseguir un objetivo, el segundo implica la acción más inmediata, centrando su atención en las consecuencias del acto más allá de la acción. En palabras de Arendt: "El acontecimiento violento es entendido como una interrupción arbitraria de la rutina cotidiana que involucra cierta agresividad e intención de ocasionar un daño" (Arendt 2006: 15). Este daño no necesariamente tiene que ser físico: aunque la máxima consecuencia de la acción violenta sea, justamente, el daño físico, también se puede considerar como acto violento un insulto, un forcejeo, un grito. En esta lógica, no sería tan importante el medio (como sí lo es en relación a la violencia), sino la intención de dañar, el acto de agredir, de lastimar, de interrumpir una acción, etcétera.

En términos de Arendt (2006), el concepto de violencia está asociado a la búsqueda de un objetivo sin limitar los medios necesarios para conseguirlo; la violencia es la manifestación de la ausencia del poder. La autora destaca como máximo exponente de la misma el estallido de una guerra. En un conflicto bélico, donde se enfrentan al menos dos partes con las mismas intenciones, los bandos rivales son capaces de armarse y desatar la furia necesaria para la concreción de una meta particular. El fundamento de toda acción violenta conlleva la consecución de un objetivo, nada más importa. En la guerra, el propósito final es la aniquilación del otro, su destrucción, sin medir las consecuencias en el uso de los instrumentos que sean necesarios a tal fin.

Puesto que la violencia debilita el poder, y los costos de llevar a cabo una guerra son muy altos -no solo en términos económicos, sino también en cantidad y calidad de agentes reclutados-, desde la antigua Grecia el uso de la guerra está más vinculado a la conquista y la defensa que al gobierno de un territorio. Los griegos supieron resolver el paso de la guerra a la política a través del uso de la persuasión; los gastos que implica todo enfrentamiento bélico fueron cambiados por el establecimiento de un parlamento con base en la idea de la democracia y en la regulación a partir del uso de las leyes. Sin embargo, esta economía en la toma de decisiones políticas no eliminó la presencia de la violencia en 
los asuntos humanos; si bien se redujo la necesidad de apelar a la guerra para ejercer el dominio sobre un territorio y su población, la violencia se mantuvo a lo largo de la historia de occidente como un instrumento -por momentos más o menos persistente- vinculado al ejercicio del poder. $\mathrm{O}$, en términos de Arendt, vinculado a la anulación del poder y al establecimiento de un dominio político explícito y sistemático más preocupado en los medios que en los fines.

\section{4 "Hacer política" a través de la violencia}

La relación entre violencia y política es clave para entender en qué medida la persuasión, puesta en escena desde la vida en la polis, reemplaza al uso de la violencia y traslada la atención del campo de batalla a la esfera de los asuntos humanos. Retomando lo desarrollado en apartados anteriores, es importante destacar que los griegos instauraron una separación entre las actividades asociadas a la acción y el discurso, otorgándole a este último la prioridad a la hora de mediar en las relaciones entre los hombres.

Esta ruptura del sometimiento a la espada, mediada por el uso de la palabra, no implica el abandono de la violencia: esta es reservada para los que se hallan por fuera de la polis, o, dentro de la misma, se dirige a aquellos que no aceptan las normas pautadas y ejecutadas por sus gobernantes. En el uso de la palabra nace la persuasión, base de la política en occidente, al mismo tiempo que se reserva el uso de la violencia para las funciones de resguardo, represión, además de las funciones más comúnmente conocidas: defensa, conquista y expansión.

Ser político, vivir en una polis, significaba que todo se decía por medio de palabras y de persuasión, y no con la fuerza y la violencia. Para el modo de pensar griego, obligar a las personas por medio de la violencia, mandar en vez de persuadir, eran formas prepolíticas para tratar con la gente cuya existencia estaba al margen de la polis (Arendt 2014: 40).

Para los romanos el uso de la violencia hacia los esclavos no resultaba algo problemático, puesto que provenían de territorios conquistados y su existencia se vinculaba a la labor requerida por otras personas; los esclavos carecían de la humanidad requerida para tener una opinión legitimada. Esta legitimación, asociada al estamento en el que se desenvuelve una persona, resultaba una condición necesaria para el uso de la palabra. Puesto que los esclavos carecían de ella, la violencia no sólo era el recurso ideal para su sometimiento, más bien era el único recurso inherente a su condición carente de 
humanidad; el esclavo, al igual que un animal domesticado, debía ser violentamente sometido y castigado si así era requerido por sus amos. La labor que demanda el cuerpo del esclavo debe ser satisfecha por el mismo esclavo; esta es una diferencia fundamental respecto de sus amos, ya que el esclavo, además de cargar con su propia labor, debe cargar con las labores de su patrón. Sólo aquellos esclavos que se mostraban conformes con la realización de las labores demandadas por sus amos podían gozar de la no-violencia de éstos.

Con los pertinentes recaudos teóricos, en Los orígenes del totalitarismo Arendt lleva a cabo un análisis comparativo entre el empleo de mano de obra forzada en los campos de concentración y la esclavitad mantenida por los romanos. Allí pretende demostrar que los internados en un campo de concentración no pueden ser concebidos como esclavos. Si los esclavos tenían un precio en tanto instrumentos y propiedad del dueño, los internados en un campo se vuelven absolutamente superfluos, no valen nada, son completamente prescindibles y por eso se los puede eliminar sin reparos:

El trabajo forzado como castigo se halla limitado en el tiempo y en la intensidad. El condenado conserva sus derechos sobre su cuerpo; no es absolutamente torturado ni es absolutamente dominado. [...] A través de la historia, la esclavitud ha sido una institución dentro de un orden social; los esclavos no eran, como son los internados en los campos de concentración, apartados de la vista y, por ello, de la protección de sus semejantes. Como instrumentos de trabajo, tenían un precio definido, y como propiedad, un valor definido. El internado en el campo de concentración no tiene precio, porque siempre puede ser sustituido; nadie sabe a quién pertenece, porque nunca ha sido visto. Desde el punto de vista de una sociedad normal es absolutamente superfluo, aunque en tiempos de aguda escasez de mano de obra, como en Rusia y en Alemania durante la guerra, es empleado para el trabajo (Arendt 1998: 652).

Una innovación de los campos de concentración radicó en que la violencia no sólo se utilizaba para corregir las desviaciones, ${ }^{7}$ sino que acompañaba permanentemente a las acciones cotidianas. El sometimiento era parte de los esfuerzos nacionalsocialistas por crear

\footnotetext{
${ }^{7}$ Michael Foucault desarrolla esta idea de la violencia vinculada al castigo correctivo, aplicado por una cadena de mando jerárquico en la que el poder se ejerce no solo a través del uso de la violencia corporal sino a través de la amenaza constante de la sentencia legal (el castigo del juez ocupa el lugar del verdugo y supone una alternativa legítima, eficiente y económica al uso explícito de la violencia). El mismo Foucault, en su libro Vigilar y castigar, afirma que en el Estado Moderno el uso de la violencia es sustituido por la vigilancia y por la presencia constante e incisiva de instituciones destinadas a mantener el orden a través de la disciplina (la escuela, el hospital, la milicia, y sobre todo la cárcel). Con la violencia en manos del sistema de gobierno, pero sin la necesidad de ejercerla (por todo un sinnúmero de recursos simbólicos), el cuerpo se transforma en un objeto de interés del poder. Un objeto de interés manipulado por la presencia constante de instrumentos de reforma, basados en la amenaza latente que supone el uso institucional de la violencia correctiva y la pérdida de derechos. Al respecto véase Patierno (2014).
} 
una ideología -amparada en una supuesta naturaleza superior- capaz de justificar la deshumanización de las poblaciones judías. Al igual que los esclavos greco-romanos, los prisioneros judíos debían autoconvencerse de que su naturaleza era inferior a la de sus amos; sólo a partir del reconocimiento de esta supuesta superioridad innata, los judíos podían acceder a la "salvación" que implicaba el trabajo forzado. Como puede verse en la película titulada La lista de Schindler, la alternativa a la muerte era conseguir un empleo. Incluso si el trabajo era considerado denigrante para la vida humana (ya que, como ha mostrado Arendt, restringir la vida al trabajo sería el equivalente a coartar las potencialidades inherentes a la completitud de la vida humana, es decir, someter al hombre a su mera capacidad productiva), ${ }^{8}$ era la única salvación en el interior de los campos.

En los centros de detención nazis, la utilidad del cuerpo apenas garantizaría la vida; la manutención de la vida dependía no solo de intentar llevar a cabo la propia labor, ${ }^{9}$ sino de la disponibilidad y requerimiento de la mano de obra. La permanencia en los campos de concentración dependía en parte del trabajo demandado por el mundo artificial del mercado vinculado a la guerra. Este mercado basó su existencia en una paradojal y morbosa relación de dominación: dependía del esfuerzo de aquellos considerados indignos de formar parte de la "superioridad" de la raza aria.

La vida en los centros clandestinos de detención creados por la última Dictadura Militar Argentina -período comprendido entre los años 1976 y 1983-, no era muy distinta a lo relevado en los escritos de Arendt respecto de los campos de concentración nazis. De hecho, según varios relatos registrados en el Informe de la Comisión Nacional sobre la

\footnotetext{
${ }^{8}$ La reducción de la existencia humana al artificio y la producción del animal laborans y del trabajo devenido en labor repetitiva y cíclica (esto es, la reducción del cuerpo a sus mecanismos musculares), serían el equivalente, en la lógica de Arendt, a una vida sin humanidad.

${ }^{9}$ Este intento desesperado por satisfacer las propias necesidades e intentar sobrevivir a una situación extrema de la mejor manera posible, me recuerda a las palabras mencionadas por un excombatiente de la guerra de Malvinas entrevistado en el marco de una investigación anterior. En sus propios términos: "Ya en los últimos días, cuando la situación era extrema, los soldados se querían volver más allá de cualquier cosa. En mi caso particular, durante los días de combate duro, intentaba no decaer el ánimo; he visto compañeros que la pasaron muy mal, les costaba de sobremanera adaptarse a la situación; yo intentaba, en la medida de lo posible, mantenerme con ganas de pelearla (comer, buscar abrigo seco, descansar, mejorar el pozo), es una búsqueda constante, de cómo estar mejor uno, independientemente de lo que pasa alrededor". Nótese que al pretender "pelearla", este excombatiente no pretendía otra cosa que vivir; o mejor dicho, revivir experiencias mundanas asociadas con la vida cotidiana. Cuando un evento catastrófico, una guerra o la privación de derechos pone en jaque la vida humana y la reduce a sus funciones vitales, los relatos de las víctimas suelen coincidir en la permanente búsqueda de esa humanidad arrebatada. Véase al respecto Patierno (2011).
} 
Desaparición de Personas, ${ }^{10}$ los centros de detención y tortura estaban decorados con esvásticas y simbologías pertenecientes al partido nacionalsocialista alemán. En dicho informe también se destina un capítulo exclusivo a la descripción de las torturas físicas recibidas por algunos sobrevivientes. En sus narraciones se destaca la obsesión de los militares por ocasionar dolor a través de la aplicación de picanas eléctricas, golpes, tabiques, disparos, ataduras, violaciones, entre otros métodos dirigidos directamente al cuerpo y a la búsqueda de su máximo sufrimiento (inmediatamente previo al punto de la muerte). La búsqueda de un dolor extremo, limítrofe con la muerte, estaba asegurada por la intervención de médicos que, según el relato de los sobrevivientes, sugerían cuándo había que interrumpir los tormentos para asegurar la perpetuidad física de la víctima. Cabe destacar que esto no suponía un alivio, sino por el contrario, el aseguramiento de una futura sesión de torturas.

No sorprende que algunos médicos, responsables (bajo juramento) de asegurar la salud de las personas más allá de su clase o ideología, trabajaran junto a los militares argentinos en los años de la dictadura, fundamentalmente colaborando en la aplicación de torturas. Incluso la iglesia estaba parcialmente aliada al actuar político de la dictadura, reescribiendo la ética comúnmente asociada al juramento, y poniendo en duda los pilares fundamentales de la religiosidad cristiana. Uno de los testimonios compilados en el Informe de la Comisión Nacional sobre la Desaparición de Personas da cuenta de lo mencionado:

Sobre la parrilla uno salta, en la medida que le permiten las ligaduras, se retuerce, se agita, y trata de evitar el contacto con los hierros calientes e hirientes. La picana era manejada como un bisturí y el especialista era guiado por un médico que decía si aún podía aguantar más. Luego de una interminable sesión me desataron y se reanudaron los interrogatorios (CONADEP 1985: 35).

Al igual que Mengele y otros tantos médicos afiliados al partido nazi, la figura del médico encarna el saber científico que garantiza la correcta aplicación de las torturas. Lejos de preguntarse por aspectos éticos, lo más importante es la eficiencia del castigo físico, procurando evitar una muerte sin sufrimiento. El cuerpo humano funciona como un medio

\footnotetext{
${ }^{10}$ La Comisión Nacional sobre la Desaparición de Personas fue creada por decisión del ex presidente de la República, Dr. Raúl Alfonsín, el 15 de diciembre de 1983. Sus principales objetivos consistían en contribuir al esclarecimiento de los hechos producidos en el país como consecuencia de la acción represiva desatada por el régimen militar instaurado en 1976. La comisión eligió como presidente al escritor Ernesto Sábato y entregó su informe al Presidente de la República el 20 de septiembre de 1984, tras relevar 7.380 legajos. Dichos expedientes comprendían denuncias de familiares de desaparecidos, testimonios de sobrevivientes de los centros clandestinos de detención y declaraciones de algunos miembros de las fuerzas de seguridad que intervinieron en el accionar represivo.
} 
para extraer información; ${ }^{11}$ la violencia es considerada el medio más eficaz, y el saber de la medicina garantiza la correcta aplicación de las técnicas dirigidas al tormento, la experimentación o la agresión deliberada. ${ }^{12}$

Tanto en la deshumanización de los prisioneros judíos por parte de los nazis, como en el empeño de los militares argentinos por aplicar torturas para extraer información, puede verse al cuerpo humano como un objeto de interés político y fin último de los medios asociados a la violencia. Sea este interés vinculado al trabajo esclavo, a la obtención de testimonios, o a la imposición de un sistema de gobierno totalitario, en todos los casos el cuerpo funciona como destino e interés final por parte de los sectores dominantes. Cuando desaparecen la palabra y la persuasión, es el cuerpo -y por añadidura el dolor y el sufrimiento al que puede verse sometido- el principal objetivo de toda forma de dominio, más preocupada por la coacción física y el consecuente establecimiento del terror que por el ejercicio del poder. Más adelante se ampliará sobre este tema.

\subsection{Los malos entendidos asociados a la violencia}

Otra de las preocupaciones de Arendt respecto del análisis de la violencia es la confusión casi automática de este término con otros parecidos. Particularmente, estos términos son poder, fuerza y autoridad. Muy lejos de significar lo mismo, no se puede desconocer su vínculo con la violencia puesto que ninguno aparece de manera "pura"; de hecho, en los asuntos humanos, no pueden aparecer conceptos puros en ningún estudio social, por más ortodoxo o veraz que se pronuncie. Una breve cita de Schutz nos recuerda esta dependencia de la investigación social respecto de la experiencia humana y la subjetividad de sus sentidos:

\footnotetext{
${ }^{11}$ En los campos nazis no se trataba de obtener información, sino de llevar a cabo la dominación total. El hecho de pertenecer a una determinada "raza" o credo religioso alternativo al cristianismo (judíos, testigos de Jehová, gitanos, etc.) era suficiente para ser catalogado como enemigo del régimen. La causa del encierro era el origen, el color de piel o la creencia, y no la posesión de información relevante.

${ }^{12}$ En el film denominado La batalla de Argel (1966), es posible observar la implementación de diversos tormentos con objetivos de obtener información relevante para los interrogadores (en este caso particular, militares franceses sobre revolucionarios argelinos). Entre estos medios se encuentran las golpizas, el ahorcamiento, la aplicación de electricidad y el ahogamiento. La aplicación de estas torturas-interrogatorios, evidenciadas en la guerra de Argelia, fueron fielmente replicadas en los centros clandestinos de detención argentinos durante la última dictadura militar. Véase al respecto el documental Escuadrones de la muerte. La escuela francesa (2003) -información completa sobre el marial fílmico mencionado, disponible en el apartado correspondiente a la filmografía-.
} 
Las Ciencias Sociales procuran comprender los fenómenos sociales en términos de categorías provistas de sentido de la experiencia humana, y por lo tanto el enfoque causal funcional de las Ciencias Naturales no es aplicable a la investigación social. [...] Un especialista en Ciencias Sociales debe construir tipos ideales o modelos en cuyos términos procura comprender la conducta social (Schutz 2008: 72-73).

Retomando las especificaciones terminológicas de la violencia sin pretender establecer verdades incuestionables, a continuación revisaremos las diferencias entre los conceptos poder y violencia en la teoría de Arendt. Mientras que el poder se basa en el dominio por vía del consenso -y la manifestación de dicha situación en un sistema legitimado por la mayoría (por ejemplo el voto en un sistema de gobierno democrático) -, la violencia puede prescindir del consenso. Puesto que la base fundamental de la violencia se basa en sus instrumentos, el dominio en esta lógica no precisa de la aprobación de la mayoría. La supresión de derechos y el terror suelen ser los medios más eficaces llevados a cabo por organizaciones políticas como la dictadura, la tiranía o el totalitarismo, cuyas intenciones de dominio, evidenciadas en la historia del siglo $\mathrm{XX}$, son llevadas a cabo a través del uso explícito de la violencia. Al respecto, sostiene Arendt:

Una de las distinciones más obvias entre poder y violencia es que el poder siempre precisa el número, mientras que la violencia, hasta cierto punto, puede prescindir del número porque descansa en sus instrumentos. [...] La extrema forma de poder es la de todos contra uno, la extrema forma de violencia es la de uno contra todos. Y esta última nunca es posible sin instrumentos (Arendt 2006: 57).

Siguiendo con esta línea, las dictaduras latinoamericanas de fines del siglo XX, resultan un claro ejemplo del dominio político mediado por el uso del terror y la violencia. Tomemos el ejemplo de la relación entre conscriptos y militares durante la Guerra de Malvinas: ${ }^{13}$ a pesar de pertenecer al mismo bando, los soldados que se sublevaban contra sus superiores eran sometidos al castigo del estaqueamineto en manos de sus propios compañeros. Si bien la orden emanaba de los militares de rango superior, eran los mismos conscriptos, movilizados por el terror de sufrir la misma pena, quienes maniataban al soldado sancionado.

\footnotetext{
${ }^{13}$ La Guerra de Malvinas fue un conflicto bélico entre la República Argentina e Inglaterra, que tuvo lugar en las islas Malvinas, Georgias del Sur y Sándwich del Sur. La guerra se desarrolló fundamentalmente entre el 2 de abril, día del desembarco argentino en las islas, y el 14 de junio de 1982, fecha acordada del cese de hostilidades. El saldo en vidas que dejó el conflicto, pasados los 74 días que duró la ocupación Argentina, fue de 649 militares argentinos, 255 británicos y 3 civiles isleños. El resultado final de la contienda permitió a Inglaterra mantener su soberanía sobre las islas, a pesar de los continuos reclamos de soberanía por parte de las máximas autoridades argentinas.
} 
La violencia puede ser justificable pero nunca será legítima. [...] La violencia puede siempre destruir al poder; del cañón de un arma brotan las órdenes más eficaces que determinan la más instantánea y perfecta obediencia. Lo que nunca podrá brotar de ahí es el poder (Arendt 2006: 72-73).

Una vez finalizada la guerra, y pasados los años de censura implícitos en el discurso político del país, los conscriptos argentinos, víctimas de los abusos de autoridad por parte de sus superiores, denunciaron los malos tratos sufridos. El uso de la violencia como refuerzo de la autoridad y aplicada a fines correctivos, no sirvió para nada más que distanciar dos facciones dentro de un mismo ejército. El estaqueamineto o cárcel de campaña, castigo previo al fusilamiento y el más común durante la guerra de Malvinas, no legitimó de modo alguno el ejercicio del poder por parte de los militares al mando.

El dominio por medio de la violencia no es otra cosa que el resultado de la pérdida de poder. La coerción nunca va estar acompañada de la legitimidad: son dos conceptos antagónicos, uno implica necesariamente la incapacidad del otro. Cualquiera ejecutaría una orden a punta de pistola, pero esto no justifica el sentido de la orden, ya que no sería más que una acción de defensa, una respuesta forzada. En términos de Arendt:

Reemplazar al poder por la violencia puede significar la victoria, pero el precio resulta muy elevado, porque no sólo lo pagan los vencidos; también lo pagan los vencedores en términos de su propio poder (Arendt 2006: 74).

Reemplazar el poder con violencia es una tentación cuando se pierde legitimidad. Esto fue lo que sucedió en la crisis Argentina del año 2001, cuando el ex presidente De La Rúa otorgó vía libre a las fuerzas policiales para desconcentrar las revueltas populares conocidas como "el cacerolazo". El éxito en la operación que buscaba dispersar a los manifestantes dejó decenas de muertos y réplicas en todo el país, forzando así la renuncia del presidente de manera precipitada hacia fines de diciembre del mismo año. Cuando un gobierno decide apelar a los instrumentos de coerción deja entrever su falta de poder; no es otra cosa que un recurso desesperado por mantener su posición de dominio. La violencia puede destruir al poder, pero no puede crearlo ni reemplazarlo; violencia y poder no son términos compatibles, de hecho son opuestos. En un gobierno totalitario, el poder no es un problema que requiere de gran atención, como sí es lo son la violencia y los intentos por efectivizar los medios para llevarla a cabo. 
Arendt asume que la única manera en que el uso de la violencia sería aceptado, sería frente a una situación de defensa. Sin embargo, cabe destacar que su uso, si bien puede ser justificado, nunca será legítimo:

La violencia puede ser justificable pero nunca será legítima. Su justificación pierde plausibilidad cuanto más se aleja en el futuro el fin propuesto. Nadie discute el uso de la violencia en defensa propia porque el peligro no sólo resulta claro sino que es actual y el fin que justifica los medios es inmediato (Arendt 2006: 72).

Esto no resulta novedoso si, como se mencionó anteriormente, analizamos el contexto en que la autora produjo sus obras: sus inicios académicos en la Alemania nazi siendo una mujer judía, su posterior encarcelación y estadía en el campo de concentración de Gurs, dan cuenta de sus reflexiones en torno a la violencia como recurso para la concreción de objetivos. Si bien habría que profundizar más al respecto, en una entrevista realizada para la televisión alemana en 1964, Arendt incluso habló de la necesidad de un ejército judío para frenar el avance militar de los nazis (claro que esta reflexión era una pretensión irreal y cronológicamente distante, probablemente basada en la impotencia de sus años de censura bajo el régimen Nacionalsocialista). En este sentido, una de las críticas de Arendt al pueblo judío alemán -por la que al mismo tiempo fue duramente criticada-radica en su falta de organización política frente al advenimiento de los acontecimientos bélicos protagonizados por el nazismo; la gravedad de estos acontecimientos ameritaba un corrimiento del lugar de espectador, para, en cambio, ejercer una resistencia activa. En su lógica de pensamiento, si la violencia fuese necesaria para escapar de una situación de riesgo, este uso sería justificado, puesto que el objetivo del otro, sin limitaciones, estaría dirigido a atentar contra la vida del o los oponentes involucrados en una contienda.

\subsection{La fuerza del cuerpo versus la mediación del lenguaje}

La fuerza, en el sentido marxista del término y vinculada al trabajo, es algo que puede poseerse o intercambiarse, incluso adquiere valor en un mercado de cambio y es factible de medir en términos económicos. Esta fuerza asociada al movimiento necesario para llevar a cabo un trabajo se suele conocer como "fuerza productiva" o "fuerza de trabajo" y es una de las principales preocupaciones de los economistas modernos, ya que gran parte de sus esfuerzos están dirigidos a hacer de esta fuerza, justamente, un producto más eficiente y menos costoso. El análisis filosófico-político del concepto de fuerza que propone Arendt no 
se reduce sencillamente a interpretar la fuerza en el sentido marxista, como algo vinculado exclusivamente al trabajo y a los medios de producción. A partir de una detallada revisión de la obra de Marx -explícita en el capítulo destinado al trabajo en La condición humana-, Arendt propone pensar la fuerza como una cualidad particular e indisociable de la existencia humana, la cual, si bien puede medirse en términos individuales, subyace al efecto de la fuerza común. Respecto de esta superioridad del consenso que implica la noción de poder en relación a la fuerza individual, Di Pego aclara lo siguiente:

El poder es el potencial estar unidos de los hombres mediante la acción y el discurso, que se mantienen mientras no se separen palabra y acto, y mientras las palabras no sean vacías y los hechos no sean brutales. Entonces, la esfera pública requiere para su existencia de poder, que no es otra cosa que esa potencialidad que emana del estar entre los hombres. A diferencia de la fuerza que pertenece a cada individuo, este no existe en el hombre aislado, sino sólo cuando los hombres actúan juntos (Di Pego 2015: 251-252).

La fuerza es entendida en la lógica de Arendt como una capacidad individual, presente en la existencia corporal del hombre y cuya potencialidad puede variar de un hombre a otro, pero siempre estará supeditada al poder. En otras palabras, solo puede existir la fuerza si las relaciones de poder así lo permiten; el cuerpo con sus características potenciales, comúnmente asociadas a la capacidad "natural" del ser humano -esto es, las posibilidades de defenderse, de atacar, de huir, de soportar golpes, de sanar heridas, etcétera-, adquieren sentido, en términos biológicos, cuando estudiamos al humano en su particularidad. Pero si pretendemos medir la fuerza individual en relación al poder de otros, la fuerza individual siempre se hallará en detrimento respecto del poder: "La fuerza (...), es indivisible, y aunque se equilibre también por la presencia de otros, la acción recíproca de la pluralidad da por resultado una definida limitación de la fuerza individual” (Arendt 2014: 224). En una jerarquía simbólica donde la violencia puede dispersar al poder, éste, al mismo tiempo, sería capaz de debilitar a la fuerza. Completando la cita de Arendt:

El poder es siempre un poder potencial y no una intercambiable, mensurable y confiable entidad como la fuerza. Mientras que ésta es la cualidad individual de un individuo visto en aislamiento, el poder surge entre los hombres cuando actúan juntos y desaparece en el momento en que se dispersan (2014: 224).

El poder de un grupo social supera la fuerza individual no solo en términos de potencia y de destrucción, lo cual sería un razonamiento lógico, sino también a partir del uso de la palabra, generando espacios para el diálogo en los que la fuerza individual se convierte en algo innecesario. En el pensamiento de Arendt, el ejercicio del poder supone la 
participación a través del acto y la palabra. Con particular atención en el uso de la palabra, es la persuasión -función intencionada del lenguaje inaugurada por los griegos para ejercer y legitimar la política- la que suplantaría la necesidad del uso individual de la fuerza y de los instrumentos de la violencia en la esfera pública de los asuntos humanos. En este sentido, Schutz afirma que

Desde el comienzo, nosotros, los actores en el escenario social, experimentamos el mundo en que vivimos como un mundo natural y cultural al mismo tiempo; como un mundo no privado, sino intersubjetivo, o sea, común a todos nosotros, realmente dado o potencialmente accesible a cada uno. Esto supone la intercomunicación y el lenguaje (Schutz 2008: 72-73).

El filósofo eslovaco Slavoj Zizek también destaca la importancia del lenguaje en la comunicación humana y resalta su valor como estrategia pacificadora. Incluso la agresión verbal o el uso del insulto suponen un reconocimiento del otro como un sujeto atravesado por el lenguaje, lo que corre a un segundo plano la necesidad de apelar a la violencia. Focalizando el análisis de la violencia como problemática social en los comienzos del siglo XXI, los aportes de Zizek resultan interesantes para comprender cuestiones actuales que interpelan a la violencia en relación a los medios de comunicación, el uso de internet y las nuevas amenazas como el terrorismo fundamentalista y la denegación fetichista. Este filósofo contemporáneo propone entender el concepto de violencia como un exceso de agresión que perturba el curso normal de las cosas. En una contienda prevalecen el desenfreno y la liberación, puesto que los adversarios desean siempre más y más. En sus propios términos:

Los adversarios en un conflicto tienen ambos una tendencia natural a exigir siempre más. Nada es suficiente para ellos, nunca se ven satisfechos. No saben cómo detenerse, no conocen límites. El deseo exige más, mucho más de lo que necesitan (Zizek 2008: 81).

Zizek ve en la política liberal del siglo XXI un sistema que avala la cotidianeidad de la violencia en los asuntos humanos y una exposición irreflexiva de la misma. Esta presencia constante de la violencia estaría exacerbada por medios como la televisión o las redes sociales. A través de una complicidad involuntaria, uno puede observar en las noticias el caso de una masacre en medio oriente, una toma de rehenes o un fusilamiento, y sin embargo no puede hacer nada al respecto, sólo continuar con su rutina diaria. Esta actitud de horrorizarse, de espantarse pero no hacer nada, es denominada por Zizek denegación fetichista. En sus propias palabras: "lo sé, pero rechazo asumir por completo las 
consecuencias de este conocimiento, de modo que puedo continuar actuando como si no lo supiese" (Zizek 2008: 81). ${ }^{14}$

A lo largo del libro de Zizek, denominado Sobre la violencia, ${ }^{15}$ es posible rastrear una lectura de Arendt pertinente a algunos temas vinculados con la violencia y el holocausto. Particularmente, el autor toma de Arendt varias cuestiones asociadas a $L a$ banalidad del mal para describir la paradojal vida de conocidos genocidas, cuyos contextos familiares y afectivos no estarían muy distantes a los de cualquier hombre común (abocado al trabajo y la rutina cotidiana). ${ }^{16}$

\subsection{Conclusiones del apartado}

Sería muy difícil encontrar una definición de violencia que abarque por completo las interpretaciones de cuerpo y naturaleza que se trabajaron a lo largo de la tesis. Esto nos permite suponer que la violencia, al igual que el resto de las construcciones sociales, carece de un sentido innato, de una esencia o de una ontología determinada. La violencia, a la par que la historia y la naturaleza, se encuentra sujeta al orden político imperante, y su uso en este sentido -generalmente vinculado a la tiranía, el autoritarismo o el totalitarismo, aunque también asociado a ciertas políticas democráticas- resulta un medio eficaz en cuanto a la obtención de resultados inmediatos. Esta eficacia se basa en la precisión de sus instrumentos; sin embargo, estos carecen de legitimidad, y por lo tanto de poder. Violencia y poder, lejos de ser lo mismo, se hallan enfrentados: el poder es la unión en relación a una dirección común, mientras que la violencia -a través de su carácter instrumental- se orienta a obtener la conducta deseada en el otro. Siguiendo a Arendt, la violencia puede destruir al poder, pero es absolutamente incapaz de crearlo (Arendt 2006: 77).

\footnotetext{
${ }^{14}$ En un trabajo desarrollado en 2014, denominado "El cuerpo como medio para la violencia en adolescentes escolarizados", propongo llevar a cabo una lectura respecto de la denegación fetichista como un recurso disparador para el abordaje de situaciones conflictivas en contextos educativos secundarios. "El concepto de denegación fetichista nos advierte sobre los riesgos de la apatía y la falta de reflexión; ejes centrales de toda propuesta educativa en relación al problema de la violencia. Toda propuesta pedagógica pertinente a esta problemática debe estar enfocada en este aspecto, es decir, en la exploración de los usos del lenguaje y las posibilidades de mitigar los factores institucionales y externos que favorezcan el surgimiento de situaciones violentas" (Patierno 2014b).

${ }^{15}$ Cabe destacar que toda vez que Zizek menciona a Arendt lo hace en términos críticos, y aun cuando toma cuestiones trabajadas por la autora en su libro Eichmann en Jerusalén, no es posible hallar en el libro del filósofo mención alguna de la bibliografía publicada por Arendt.

${ }^{16}$ Las complejas relaciones entre Zizek y la obra de la filósofa alemana serán abordadas en un trabajo posterior
} 
Si bien existen tantas definiciones de violencia como destinos de la misma, sería una generalización abusiva utilizar el término para explicar cualquier problemática social, sin llevar a cabo una minuciosa contextualización e historización al respecto. En los comienzos del siglo XXI, es posible hallar el uso frecuente de términos como "violencia barrial", "violencia escolar", "violencia en el deporte", "violencia de género", "violencia en el tránsito", etcétera. Desde mi punto de vista, esto es una interpretación ahistórica de la violencia y un reduccionismo al caso particular, dejando al lado el recorrido del término vinculado a la historia y la política, tarea cuidadosamente llevada a cabo por Arendt a lo largo de sus obras. El relevamiento que inicia la autora en Los orígenes del totalitarismo, y termina veinte años después con la publicación del libro titulado Sobre la violencia, da cuenta no sólo de la ausencia de análisis reflexivos y filosóficos en torno al tema de la violencia en occidente, sino también de las intenciones de varios gobiernos por el uso de sus instrumentos.

Considerados por Arendt como extremadamente eficaces y peligrosos, los instrumentos de la violencia no se agotan en las clásicas armas de guerra; estos abarcan todo aquello que priorice la ciega consecución de un fin. Esto incluiría desde el uso del propio cuerpo, hasta la sanción de una ley opresiva o la imposición de una orden, solo para nombrar algunos ejemplos recurrentes. Esta interpretación, más que aclarar, amplía la problematización de la violencia, asumiendo que es parte de los asuntos humanos, y, por lo tanto, su uso siempre conllevará una intencionalidad política en un marco histórico determinado. 


\section{Conclusiones}

El cuerpo es lo que nos identifica como humanos, es a través del cuerpo que conocemos el mundo que habitamos, con el cuerpo nos movemos, hablamos, nos relacionamos con otras personas; en términos arendtianos, el cuerpo nos posibilita el recorrido por una infinidad de acciones, cuyas consecuencias no podemos predecir ni calcular.

Más que a una conclusión, esta breve revisión respecto de la noción de cuerpo en la teoría Arendt nos invita a pensar sobre el mismo más allá de la reducción a sus características físicas; no sería factible compararlo con un mero conjunto de órganos, ni con la materia inerte que descansa sobre una mesa de disecciones. El cuerpo tampoco sería esa obra divina que intenta recrearse en las figuras inmortalizadas de los dioses griegos, ni una mera animalidad -condición asignada por compartir el mundo con otras especies. El cuerpo tampoco encontraría su precisa descripción en la ideología cristiana que lo interpreta como el envase del alma, como el culpable de los pecados terrenales o como lugar de paso hasta la inmortalidad que prosigue a la muerte física. En la teoría de Arendt, el cuerpo se define a partir de sus acciones, es a través de la mundanidad de lo cotidiano que podemos hallar aquello que nos constituye como humanos, que nos separa de otras especies y que nos brinda sentido en el mundo que habitamos. El cuerpo humano encuentra su explicación, no a través de explicaciones trascendentales y metafóricas, sino a partir del modo en que nos movemos, la forma en que dormimos, comemos, nos vestimos, nos aseamos, etcétera.

Teniendo en cuenta lo mencionado anteriormente, el abanico de acciones posibles conlleva infinitas consecuencias: por lo tanto, aquello que define al cuerpo al mismo tiempo le otorga su carácter de indefinición. Así, si pretendiéramos describir las acciones posibles a ser llevadas a cabo por un sujeto a lo largo de su vida y las consecuencias de las mismas, nos veríamos imposibilitados de continuar a partir del momento del nacimiento. Dada la imprevisibilidad de las acciones, cabría afirmar que hay infinitas posibilidades de concebir el cuerpo. Sin embargo, esto no acontece en la vida moderna, puesto que el marco político en que se desarrolla la vida de un sujeto va a recortar el abanico de acciones que se encuentran a su alcance y, por lo tanto, la naturaleza del cuerpo involucrado. La modernidad es un claro ejemplo de cómo la naturaleza del cuerpo se amolda al orden político imperante. 
¿Cómo es interpretado el cuerpo en la época moderna? La modernidad lo ubica en un hacer tangible, medible que no encuentra relación alguna con las actividades de la reflexión, del pensar (actividades comúnmente asociadas a la idea de la contemplación). Palabra y acto pasan a ocupar esferas diferentes, espacios donde el hacer puede estar escindido del pensar. Este dualismo es el que posibilitó el origen del pensamiento de Marx sobre la alienación de las fuerzas de producción, y el que posibilita la existencia, en términos de Arendt, de una condición humana particularmente limitada -más específicamente la del homo faber, asociada al trabajo, y la del animal laborans, cuya existencia irreflexiva, comparable a un eslabón en una cadena de producción fabril, lo ubica como un ser abocado a su efímera función de consumir. En esta lógica quedan excluidas las posibilidades de acción asociadas a la idea de libertad, ya que el pensar no es requerido ni para la fabricación -que se apoya en la simple extracción e imitación-, ni para el consumo que se mueve al ritmo del mercado.

Solo a través del ejercicio de la acción, alguien podría considerarse libre de hacer y decir lo que desee -pero esta condición conlleva un precio muy alto: basta realizar un recorrido por la complejidad política del siglo XX para darse que cuenta de que el costo de la libertad política en muchos casos es la vida misma. En los campos de exterminio masivos, máximos exponentes del sistema de gobierno totalitario, donde cada acción y sus consecuencias están cuidadosamente predeterminadas, el abanico de acciones posibles se ve reducido a sólo dos: desligarse del control a través de la muerte o padecer la desdichada sumisión de una vida exclusivamente biológica. La des-humanización consiste en reducir el hombre a sus funciones vitales, cuando no hay más que vida orgánica, no hay condición humana posible. Para los prisioneros judíos no había posibilidad de acción alguna más que inducir la propia muerte, que en este caso era más humana que la vida, reducida tan solo a proteger el mínimo funcionamiento de los órganos vitales.

El tránsito de Hannah Arendt por un campo de concentración, específicamente por el campo de Gurs en Francia, muy probablemente le haya despertado el interés por el abanico de posibilidades que la condición humana permite experimentar una vez solventada la demanda de la vida biológica. No habría peor castigo en el paso por el mundo que habitamos, que padecer la condena de una vida exclusivamente orgánica. Todo lo que se construye por encima del cuerpo biológico es lo que nos define como humanos, y en la 
concepción de cuerpo aquí desarrollada, cabe afirmar que es a través de las acciones que lo humano se pone en juego.

La preocupación por la satisfacción de las necesidades biológicas sentencia al humano a encerrarse en las demandas de su propio cuerpo. El problema central que resalta Arendt, en su análisis sobre la condición humana y la política contemporánea, sale a la luz cuando la amenaza de padecimiento de una vida únicamente biológica se encuentra en manos de un sistema de gobierno. Aquí la violencia se transforma en una herramienta fundamental -es a través del uso de la violencia que la vida biológica se transforma en el objetivo final de todo acto de coerción. El cuerpo es el objetivo y al mismo tiempo el medio para el ejercicio de la violencia, todo depende del lugar que se ocupe en la distribución de roles en el orden político imperante. Cometer una agresión, jalar un gatillo o asentir a decisiones políticas tiránicas, en principio podrían parecer actos muy distintos. Sin embargo, tienen un objetivo en común, el ejercicio respecto del control de la vida; esto recortaría el abanico de acciones posibles y por lo tanto garantizaría una vida enmarcada dentro de ciertos actos predeterminados.

El temor por la pérdida del derecho a la vida humana en su plenitud es el motor de una inquisidora introspección que atraviesa las acciones que llevamos a cabo cotidianamente. Bajo la amenaza de una existencia meramente orgánica -similar a la animalidad-, nos envolvemos bajo el manto de acciones socialmente aceptadas que suponen cierta noción de liberación, cuando en realidad, esta liberación depende de la satisfacción de nuestras necesidades más elementales. Sólo una vez superada la condición de animal laborans, es decir, cuando dejamos de ser rehenes de las necesidades vitales de nuestro cuerpo, estaríamos en condiciones de vivir la condición humana en su plenitud. Es a través de pensadoras como Arendt que podemos identificar cuándo los sistemas políticos -los grotescos sistemas despóticos y tiránicos amparados en el uso de la violencia, pero también ciertos sistemas democráticos basados en la utilización de la violencia- llevan a cabo un uso intencionado del dominio a través del terror y de la manipulación de la naturaleza humana. 


\section{Bibliografía general}

- Archenti, N. (2007). "El papel de la teoría en la investigación social”. En: Archenti, N., Marradi, A. y Piovani, J. Metodología de las ciencias sociales. Buenos Aires: Emecé. 61-67.

- Arendt, H. (1959). "Reflections on Little Rock". En Dissent. New York, Winter 1, 45-56 [Traducido por María Cristina Daponte].

- ---------- (1996). Entre el pasado y el futuro. Barcelona: Península.

- ---------- (1998). Los orígenes del totalitarismo. Madrid: Aguilar.

- ---------- (1999). Eichmann en Jerusalén. Un estudio sobre la banalidad del mal.

Buenos Aires: Lumen.

- --------- (2005). “¿Qué queda? Queda la lengua materna. Conversación con Günter Gauss". En Ensayos de comprensión 1930 - 1954. Barcelona: Caparrós Editores, 17-40.

-

- ----------- (2008). De la historia a la acción. Barcelona: Paidós.

- ---------- (2014). La condición humana. Buenos Aires: Paidós.

- Bachelard, G. (1978). “Conocimiento común y conocimiento científico”. En El racionalismo aplicado. Buenos Aires: Paidós, 13-99.

- Bleichmar, S. (2010). Violencia social - Violencia escolar. De la puesta de límites a la construcción de legalidades. Buenos Aires: Noveduc.

- Bourdieu, P. (1998). Capital cultural, escuela y espacio social. Madrid: Siglo XXI editores.

- Carballo, C. (coord.) (2015). Diccionario Crítico de la Educación Física Académica. Buenos Aires: Prometeo.

- Comisión Nacional sobre la Desaparición de Personas (1985). Nunca Más. Buenos Aires: EUDEBA.

- Crisorio, R. (2009). “El cuerpo y las prácticas corporales”. En El monitor. Sumario $\mathrm{N}^{\mathrm{O}}$ 20, Marzo. Disponible 
http://www.me.gov.ar/monitor/nro0/pdf/monitor20.pdf. Consultado el 31 de julio de 2015.

(2010). Homero y Platón: dos paradigmas de la Educación

Corporal. Tesis de Doctorado en prensa. Universidad Nacional de La Plata, Facultad de Humanidades y Ciencias de la Educación.

- Cruz, M. (2008). "Introducción”. En: Arendt, H. De la Historia a la acción. Barcelona: Paidós, 9-27.

- Di Pego, A. (2005). "Lo social y lo público en la obra de Hannah Arendt. Reconsideraciones sobre una relación problemática”. En: Intersticios. Año 10, núms. 22-23, 36-69.

----------- (2010). “Biopolítica y totalitarismo en Hannah Arendt”. En Paz Echevarría y Pamela Vestfrid (coords.). Tridecaedro: jóvenes investigadores en Ciencias Sociales de la UNLP. La Plata: Editorial de la Universidad de La Plata, 6274.

(2013). Arendt: Una reinterpretación a partir de los escritos de Walter Benjamin y Martin Heidegger. Tesis de Doctorado en prensa. Universidad Nacional de La Plata, Facultad de Humanidades y Ciencias de la Educación. (2015). Totalitarismo y sociedad de masas en Hannah Arendt. La Plata: Editorial de la Universidad de La Plata.

- Foucault, M. (1999). "Nacimiento de la medicina social”. En Estrategias de poder. Obras esenciales II. Barcelona: Paidós, 363-384.

- - ----------- (2002). Vigilar y Castigar. Madrid: Siglo XXI Editores.

- ------------ (2008). La Arqueología del saber. Madrid: Siglo XXI Editores.

- ------------- (2010). ¿Qué es un autor? México D. F.: Ediciones Literales.

- Hilb, C. (2001). "Violencia y política en la obra de Hannah Arendt". En Revista Sociológica. Año 16, número 47, 11-44.

- Hughes, J. y W. Sharrock (1987). La Filosofía de la investigación social. México D. F.: Fondo de Cultura Económica.

- Husserl, E. (1992). Invitación a la fenomenología. Barcelona: Paidós.

- ------------- (2006). La tierra no se mueve. Madrid: Editorial Complutense. 
- Loyola, J. (2011). "La ignorancia del poder. Acerca de la violencia y el mal en la filosofía política de Hannah Arendt”. En Estudios de filosofía. Vol. 9, 27-43.

- Monteagudo, J. (2000). "El paradigma interpretativo en la investigación social y educativa: nuevas respuestas para viejos interrogantes". En Cuestiones pedagógicas: Revista de ciencias de la educación, 15, 227-246.

- Quiroz Ospina, D. (2015). "La crisis de la humanidad y las ciencias del espíritu. Los proyectos de humanismo de Husserl y Gadamer". En Revista Versiones, $2^{\circ}$ época, $8,117-136$.

- Patierno, N. (2011). Viento Sur. Seis excombatientes narran sus historias a lo largo de una travesía por los caminos de la Patagonia. La Plata: Ediciones Al Margen.

- ----------- (2014a). “Cuerpo y violencia en la Escuela Secundaria Básica”. En I Encuentro Internacional de Educación: espacios de investigación y divulgación, 29-31 de Octubre. Universidad Nacional del Centro de la Provincia de Buenos Aires, Tandil, Argentina.

----------- (2014b). “El cuerpo como medio para la violencia en adolescentes escolarizados". En XV Encuentro Nacional, X internacional de investigadores en Educación Física, 16-18 de Octubre. Universidad de la República, Montevideo, Uruguay.

- Patierno, N y L. Rocha Bidegain (2015). "Introducción al concepto de cuerpo en la teoría de Hannah Arendt". En $11^{\circ}$ Congreso Argentino y $6^{\circ}$ Latinoamericano de Educación Física y Ciencias, 28 de Septiembre - 2 de Octubre. Universidad Nacional de La Plata, Ensenada, Argentina.

- Real academia española (2012). Diccionario de la lengua española (22 edición). En línea: http://www.rae.es/recursos/diccionarios/drae. Consultado el 12 de agosto de 2015.

- Reyes, R. y E. Solana (2007). "El cuerpo y las Ciencias Sociales”. En Revista Pueblos y Frontera digital. Núm. 4. En línea: http://www.pueblosyfronteras.unam.mx/a07n4/pdfs/n4_art02.pdf. Consultado el 15 de febrero de 2016.

- Schutz, A. (2008). El problema de la realidad social. Buenos Aires: Amorrortu editores 
- Serrano de Haro, A. (2006). "Introducción”. En Husserl, E. La tierra no se mueve. Madrid: Editorial Complutense, 7-9.

---on (2008). "Husserl en el pensamiento de Hannah Arendt". En Revista Investigaciones Fenomenológicas. Núm. 6, 299-308.

- Tapia Navarro, J. (2008). "Hannah Arendt, el cuerpo y la fábrica política. En Revista Metapolítica. Número 62, 135-139.

- Vasilachis, I. (2013). Estrategias de investigación cualitativa. Barcelona: Editorial Gedisa.

- Von Wright, G. H. (1979). "Dos tradiciones”. En Explicación y comprensión. Madrid: Alianza, 19-58.

- Zamora, A. (2010). "H. Arendt y TH. W. Adorno: pensar frente a la barbarie". En Revista ARBOR Ciencia, Pensamiento y Cultura. CLXXXVI 742, 245-263.

- Zizek, S. (2008). Sobre la violencia. Seis reflexiones marginales. Buenos Aires: Editorial Paidós. 


\section{Filmografía}

- Escuadrones de la muerte. La escuela francesa. Año: 2003. Directora: MarieMonique Robin. Países: Argentina, Francia.

- Hannah Arendt. Año: 2012. Directora: Margarethe von Trotta. Países: Alemania, Luxemburgo y Francia.

- Hannah Arendt. Pensar apasionadamente [documental]. Año: 2006. Director: Jocken Kölsch. País: Alemania. Disponible en: https://www.youtube.com/watch?v=zaHHP2h-nDs. Consultado el 27 de julio de 2015.

- La batalla de Argel. Año: 1966. Director: Gillo Pontecorvo. Países: Italia, Argelia.

- La lista de Schindler. Año: 1993. Director: Steven Spielberg. País: Estados Unidos.

- La ola. Año: 2008. Director: Dennis Gansel. País: Alemania.

- ¿Qué queda? Queda la lengua materna. Entrevista a Hannah Arendt realizada por Günter Gauss y emitida por la televisión de Alemania Occidental el 28 de Octubre de 1964. Disponible en: https://www.youtube.com/watch?v=WDovm3A1wI4. Consultado el 27 de julio de 2015.

- Hijos de los hombres. Año: 2006. Director: Alfonso Cuarón. País: España.

- The Eichmann Show. Año: 2015. Director: Paul Andrew Williams. País: Inglaterra 